Aus der Abteilung für Transfusionsmedizin

(PD Dr. med. J. Riggert)

der Medizinischen Fakultät der Universität Göttingen

\title{
Inhibition des
}

\section{microRNA-Clusters 17-92 als mögliche Leukämietherapie}

\author{
INAUGURAL-DISSERTATION \\ zur Erlangung des Doktorgrades \\ der Medizinischen Fakultät der \\ Georg-August-Universität zu Göttingen \\ vorgelegt von \\ Anne Lone Rau \\ aus \\ Bad Oldesloe
}

Göttingen 2017 
Dekan:

Referent/in:

Koreferent/in:

Drittreferent/in:

Datum der mündlichen Prüfung: $\quad$ 11.10.2017
Prof. Dr. rer. nat. H. K. Kroemer

Prof. Dr. med. T. J. Legler

Prof. Dr. med. G. Wulf

Prof. Dr. hum. biol. M. Schön 
Hiermit erkläre ich, die Dissertation mit dem Titel "Inhibition des microRNAClusters 17-92 als mögliche Leukämietherapie" eigenständig angefertigt und keine anderen als die von mir angegebenen Quellen und Hilfsmittel verwendet zu haben.

Göttingen, den …........................

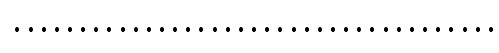

(Unterschrift) 


\section{Inhaltsverzeichnis}

1 Einleitung $\quad 1$

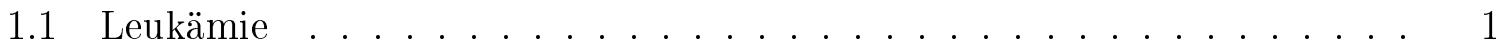

1.1.1 Akute Lymphatische Leukämie (ALL) . . . . . . . . . . . 2

1.2 Therapieoptionen bei ALL . . . . . . . . . . . . . . 3

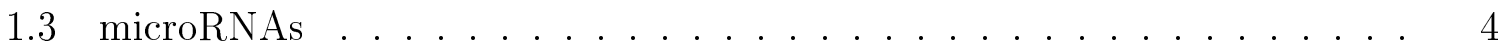

1.3.1 Biogenese von microRNAs .............. 5

1.3.2 Interaktion von microRNA und Ziel-mRNA . . . . . . . . 5

1.3.3 microRNAs in der normalen Hämatopoese . . . . . . . . . . . 6

1.3.4 microRNA-Expression bei ALL ............. 7

1.4 microRNA-Cluster $17-92 \ldots \ldots \ldots \ldots$

1.5 Inhibition von microRNAs . . . . . . . . . . . . . 10

1.5.1 Klassen von microRNA-Inhibitoren ............ 10

1.5.2 Methoden zum Einbringen von microRNA-Inhibitoren in Zellen • 11

1.5.3 Inhibition von microRNAs in klinischen Studien . . . . . . . . 13

1.5.4 Inhibition des microRNA-Clusters 17-92 . . . . . . . . 15

1.6 Ziele der Arbeit ....................... 16

2 Material und Methoden $\quad 18$

2.1 Arbeitsmaterialien und Reagenzien .............. 18

2.2 Bestimmung der Apoptose- und Transfektionsrate . . . . . . . . . . . . 22

2.3 Generelle Informationen zu Versuchsbedingungen . . . . . . . . . . . 23

2.4 Vorbereitung der Zellkulturen . . . . . . . . . . . . . 23 
2.4.1 Kultivierung, Vermehrung und Kryokonservierung von Jurkat- und SU-DHL-4-Zellen . . . . . . . . . . . . . . 23

2.4.2 Gewinnung mononukleärer Zellen aus Buffy Coats . . . . . . . 25

2.5 CD 45-Annexin V-Färbung von Jurkat-Zellen und humanen mononukleären Zellen . . . . . . . . . . . . . . . 26

2.6 Resuspension und Aliquottierung des microRNA-Inhibitors und der microRNA-Kontrolle........................ 27

2.7 Analyse der Transfektionsbedingungen bei Jurkat-Zellen . . . . . . . . 28

2.8 Analyse der Transfektionsbedingungen bei SU-DHL-4-Zellen . . . . . . . 30

2.9 Analyse der Transfektionsbedingungen bei humanen mononukleären Zellen 32

2.10 Transfektions- und Apoptoserate von Jurkat-Zellen bei Transfektion mit dem microRNA-Inhibitor $19 b \ldots \ldots . \ldots \ldots$

2.11 Transfektions- und Apoptoserate von humanen mononukleären Zellen bei Transfektion mit dem microRNA-Inhibitor 19b . . . . . . . . . 36

2.12 Transfektions- und Apoptoserate von Leukozytensubpopulationen . . . . 38

$\begin{array}{lll}3 & \text { Ergebnisse } & 41\end{array}$

3.1 Transfektionsbedingungen bei Jurkat-Zellen . . . . . . . . . . . 41

3.2 Transfektionsbedingungen bei SU-DHL-4-Zellen . . . . . . . . . . 43

3.3 Transfektionsbedingungen bei humanen mononukleären Zellen . . . . . . 45

3.4 Transfektions- und Apoptoserate von Jurkat-Zellen bei Transfektion mit dem microRNA-Inhibitor $19 b \ldots \ldots \ldots$. . . . . . . . . 47

3.5 Transfektions- und Apoptoserate von humanen mononukleären Zellen bei Transfektion mit dem microRNA-Inhibitor $19 \mathrm{~b} \ldots \ldots . \ldots$

3.6 Transfektions- und Apoptoseraten von Leukozytensubpopulationen . . . 52

3.6.1 Transfektionsraten von T-Lymphozyten, B-Lymphozyten und Mo-

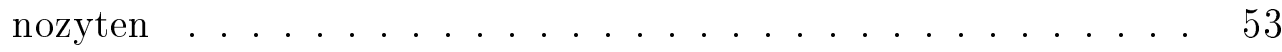


3.6.2 Apoptoseraten von T-Lymphozyten, B-Lymphozyten und Mono-

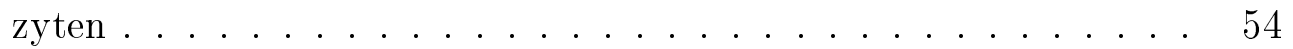

4 Diskussion $\quad 58$

4.1 Transfektionsbedingungen . . . . . . . . . . . . . 58

4.1.1 Transfektionsbedingungen bei Jurkat- und SU-DHL-4-Zellen . . . 58

4.1.2 Transfektionsbedingungen bei humanen mononukleären Zellen . . 60

4.2 Effekt des microRNA-Inhibitors $19 \mathrm{~b} \ldots \ldots \ldots 61$

4.2.1 Auswirkungen der Transfektion mit dem microRNA-Inhibitor 19b auf Jurkat-Zellen . . . . . . . . . . . . . . 61

4.2.2 Auswirkungen der Transfektion mit dem microRNA-Inhibitor 19b auf humane mononukleäre Zellen . . . . . . . . . . . . . 63

4.3 Effekte von microRNAs auf T-Lymphozyten, B-Lymphozyten und Mono-

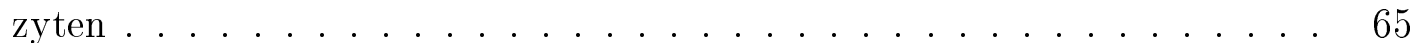

4.4 Fazit und Ausblick ...................... 69

$\begin{array}{lll}5 & \text { Zusammenfassung } & 71\end{array}$

$6 \quad$ Literaturverzeichnis $\quad 73$ 


\section{$1 \quad$ Einleitung}

\subsection{Leukämie}

Bei einer Leukämie handelt es sich um eine Krebserkrankung des blutbildenden Systems, die durch eine pathologische Vermehrung von myeloischen oder lymphatischen Blutzellen entsteht und in der Regel zu einer stark erhöhten Zahl von Leukozyten im Blut führt. Laut Ferlay et al. (2013) wurde 2012 in Europa bei ca. 82.000 Menschen eine Leukämie diagnostiziert.

Generell werden akute und chronische Leukämien unterschieden. Zusätzlich werden die Leukämien nach ihrem Ursprungszelltyp in myeloische und lymphatische Leukämien unterteilt. Die Beschwerden der Patienten sind je nach Leukämieart sehr unterschiedlich und hängen von der jeweils betroffenen Zellart und den erkrankten Organen ab. Auch die Therapie ist von Form und Verlauf der Leukämie abhängig und ist für die Akute Lymphatische Leukämie beispielhaft in Abschnitt 1.2 beschrieben.

Die Prognose eines Leukämieerkrankten ist stark von der Leukämieart und von seinem Alter abhängig. Insgesamt ist das 5-Jahres-Überleben von US-amerikanischen Leukämieerkrankten aller Altersgruppen laut Siegel et al. (2016) von im Mittel 34\% in den Jahren 1975 bis 1977 auf 62\% in den Jahren 2005 bis 2011 deutlich angestiegen. Dies konnte durch ständige Verbesserung der Therapien erreicht werden. Trotz der genannten Erfolge gibt es jedoch auch heute Leukämiekranke, denen nicht geholfen werden kann, sodass weitere Forschung nötig ist. 


\subsubsection{Akute Lymphatische Leukämie (ALL)}

Eine bekannte Form der Leukämie ist die Akute Lymphatische Leukämie (ALL). Bei der ALL handelt es sich um eine seltene Erkrankung mit einer Gesamtinzidenz von 1,1/100.000 pro Jahr. Am häufigsten sind Kinder unter fünf Jahren betroffen (Sather 1986). Der zweite Häufigkeitsgipfel liegt bei den über 80-Jährigen.

Eine ALL entwickelt sich bei überschießender Proliferation von lymphoiden VorläuferZellen (Blasten) im Knochenmark, die entweder der T- oder der B-Zelllinie angehören. Die Zelldifferenzierung und Reifung dieser Vorläufer-Zellen ist durch Mutationen blockiert, sodass sich der maligne Klon vermehren und ausbreiten kann. Das normale Knochenmark wird sukzessive verdrängt, die entstandenen Blasten im Verlauf der Erkrankung ins periphere Blut ausgeschwemmt und zum Teil auch andere Organe infiltriert (Sawyers et al. 1991). Als klinische Symptome zeigen sich vor allem Schwäche und Anämie (Verdrängung der Erythrozytopoese im infiltrierten Knochenmark), Blutungen und Petechien (Verdrängung der Thrombozytopoese) oder Infektionen (verdrängte Granulozytopoese).

Die Prognose der ALL-Erkrankung hat sich durch die in Abschnitt 1.2 beschriebenen Therapieoptionen in den letzten Jahrzehnten insgesamt stark verbessert (Schrappe et al. 2000). Bei einem Rezidiv der ALL ist die Prognose jedoch sowohl bei Kindern als auch bei Erwachsenen weiter ungünstig (Gökbuget et al. 2012). Unterschieden werden je nach vorhandenen Risikofaktoren ALL mit Standardrisiko, Hochrisiko und Höchstrisiko. Entscheidend für diese Einstufung sind vor allem die Leukozytenzahl $(<50.000 / \mu l$ günstig), der Immunphänotyp (B-Vorläufer-ALL günstig, T-ALL ungünstig), die Zytogenetik (Risiko je nach Chromosomen- oder strukturellen Veränderungen) sowie die Ausprägung der erreichten Remission am Ende der Induktion (Preiss et al. 2014). 


\subsection{Therapieoptionen bei ALL}

Noch vor einigen Jahrzehnten war die Diagnose einer ALL ein Todesurteil. Heutzutage ist die Erkrankung jedoch bei vielen Patienten heilbar.

Es stehen viele Therapiemöglichkeiten zur Verfügung wie zytostatische Therapien, allogene Stammzelltransplantation mit vorhergehender Ganzkörperbestrahlung und neuere Medikamente, die auf den Immunphänotyp der Erkrankung abzielen. Wichtig ist bei der ALL darüber hinaus die Durchführung einer effektiven Prophylaxe von ZNS-Rezidiven beispielsweise durch intrathekale Gabe von Methotrexat.

Die klassische zytostatische Therapie erfolgt zyklisch und ist abhängig vom jeweils erreichten Remissionsstatus eines Patienten. Verwendet werden beispielsweise Substanzen wie Daunorubicin, Dexamethason, Asparaginase, Cytarabin oder Methotrexat. Die allogene Stammzelltransplantation kommt in der 1. Remission bei Patienten mit Hoch- oder Höchstrisiko in Frage sowie bei allen Patienten in der 2. Remission oder mit zytostatikarefraktärer ALL. Sie ist gegenwärtig die Therapie mit dem höchsten kurativen Potential für Patienten mit Hochrisiko-ALL.

Neben der klassischen Chemotherapie mit Zytostatika gibt es spezifischere Therapien, die auf den Immunphänotyp der Erkrankung abgestimmt sind. Ein Beispiel hierfür ist der Thyrosinkinaseinhibitor Imatinib, der bei Philadelphia-Chromosom-positiver ALL eingesetzt wird und zu Remissionsraten von bis zu 90\% führt (Ottmann und Pfeifer 2009). Weiterhin kann der CD20-Antikörper Rituximab bei B-Vorläufer-ALL mit CD20Expression eingesetzt werden. Bei B-Vorläufer-ALL kann zudem ein Antikörper gegen CD19 wie der bispezifische Antikörper Blinatumomab eingesetzt werden. Er ist einerseits gegen CD19 gerichtet und bindet andererseits CD3-positive Lymphozyten, die dadurch aktiviert werden und die gebundene Zelle zerstören. Es wurden unter Blinatumomab Ansprechraten von $80 \%$ berichtet und einige Patienten blieben auch ohne weitere Therapie in Langzeitremission (Topp et al. 2012). Ein weiterer vielversprechender Angriffspunkt bei Patienten mit B-Vorläufer-ALL ist der anti-CD22-Antikörper Inotuzumab, der mit 
dem zytotoxischen Wirkstoff Calicheamicin konjugiert ist. Bei Behandlung von Patienten mit refraktärer oder rezidivierter ALL wurde insgesamt eine Ansprechrate von ca. 60\% erreicht (Kantarjian et al. 2013).

Beim neuesten Therapieansatz zur Behandlung der ALL handelt es sich um TLymphozyten, in die das Gen für die antigen-bindende Region eines monoklonalen Antikörpers (Chimeric antigen receptor $(\mathrm{CAR})$ ) mit Hilfe von Viren eingebracht (transduziert) wurde. Diese T-Lymphozyten eliminieren die Ziel-Tumorzellen über Bindung des Antikörperrezeptors an ein tumor-assoziiertes Antigen z.B. CD19. Mit diesem Mechanismus konnte bei Kokultivierung der CD19-positiven Leukämie-Zelllinie Nalm-6 mit den mit CAR transduzierten T-Lymphozyten eine vollständige Zerstörung der Leukämiezellen innerhalb von 24 Stunden festgestellt werden. In einem B-ALL-Mausmodell mit CD19-positiven Leukämiezellen wurde durch Behandlung mit CAR exprimierenden Nalm-6-Zellen die Überlebenszeit der Mäuse signifikant verlängert (An et al. 2016). Von Dai et al. (2016) wurde zudem kürzlich der klinische Nutzen bei Patienten evaluiert, die mit transduzierten T-Lymphozyten gegen CD19 behandelt wurden.

Zusätzlich zu den genannten Therapien hat sich in den letzten Jahren immer weiter herauskristallisiert, dass die Dysregulation von microRNAs ein entscheidender Faktor bei der ALL ist. Untersuchungen konnten hier zeigen, dass in vielen Leukämiearten eine veränderte Expression von microRNAs im Vergleich zu gesunden Zellen nachweisbar ist (Li Q et al. 2014). Dementsprechend ist es wünschenswert, Therapien zu entwickeln, die auf diese veränderte Expression der microRNAs abzielen. Daher werden in den folgenden Abschnitten die Eigenschaften, Bedeutung und eine mögliche Leukämietherapie mit microRNAs beschrieben.

\section{3 microRNAs}

Bei microRNAs handelt es sich um 20 bis 24 Nukleotide umfassende nicht-kodierende RNAs, die mehr als 60\% der menschlichen Gene regulieren (Bartel 2009). Diese Gen- 
regulation findet post-transkriptional statt (Zamore und Haley 2005). Es werden von microRNAs verschiedene biologische Prozesse wie die Apoptose, die Insulinsekretion, der Lipidmetabolismus, die Zelldifferenzierung und das Altern reguliert (Undi et al. 2013). Einige dieser Funktionen werden in diesem Abschnitt näher beschrieben.

\subsubsection{Biogenese von microRNAs}

MicroRNAs entstehen in einem mehrere Schritte umfassenden Prozess. Als Vorläufer einer microRNA entsteht im Zellkern zunächst die pri-microRNA durch Transkription des entsprechenden Gens mittels RNA-Polymerase. Durch die Enzyme Drosha und Dicer wird die pri-microRNA im Zytoplasma zur reifen microRNA umgebaut. Diese wird in den RNA-induced silencing complex (RISC) eingegliedert und kann so den 3'-untranslatierten Bereich von messengerRNAs (mRNAs) binden. Die Bindung von microRNA und mRNA erfolgt am RISC-Komplex durch komplementäre Basenpaarung der Nukleotide 2-8 der microRNA, vom 5'-Ende aus gesehen, mit den entsprechenden Basen der mRNA (Doench und Sharp 2004). Diese 7 Nukleotide der microRNA, die die mRNA binden, werden als seed-Region bezeichnet und machen die Funktion der microRNA aus (Lewis et al. 2003).

\subsubsection{Interaktion von microRNA und Ziel-mRNA}

Eine Möglichkeit der reduzierten Genexpression von mRNAs durch microRNAs ist die Spaltung der mRNA am RISC-Komplex. Dies ist jedoch nur möglich, wenn die Sequenzen von microRNA und mRNA vollständig komplementär sind. Eine zweite Möglichkeit der Genregulation durch microRNAs ergibt sich aus der Hemmung der Translation der mRNA. Dies kommt vor, wenn die Sequenzen von microRNA und mRNA nicht vollständig komplementär sind. Durch die Bindung der mRNA an die microRNA im RISC-Komplex wird der Beginn der Translation oder die Verlängerung der Aminosäurekette verhindert (Brennecke und Cohen 2003). Als weitere Möglichkeit der Genregulation

durch microRNAs gilt die Deadenylierung der mRNA mit nachfolgendem Abbau (Eulalio et al. 2009). Zudem haben einige Studien gezeigt, dass microRNAs auch direkt an 
die DNA binden und so die Transkription verhindern können (Garzon et al. 2010). Die Beeinflussung der Genexpression durch microRNAs ist nach aktuellem Kenntnisstand also über viele verschiedene Wege möglich. Bemerkenswert ist hierbei auch, dass eine microRNA verschiedene mRNAs binden und dadurch mehrere Protein-kodierende Gene regulieren kann (Lewis et al. 2005). Anders herum haben auch viele mRNAs unterschiedliche microRNAs als potentielle Inhibitoren.

Generell können microRNAs tumorbegünstigende, also onkogene, oder tumorunterdrückende, als supprimierende, Eigenschaften haben. Jedoch ist es nicht möglich einer microRNA pauschal eine dieser Eigenschaften zuzuordnen, denn eine microRNA kann in verschiedenen Geweben oder Zelltypen unterschiedliche Funktionen ausüben (Croce 2009).

\subsection{3 microRNAs in der normalen Hämatopoese}

Die Hämatopoese ist ein Prozess, bei dem sich multipotentente hämatopoetische Stammzellen (HSCs) zum einen selbst erneuern und zum anderen zu verschiedenen Zellen differenzieren. microRNAs spielen bei fast jeder Entwicklungsstufe der Hämatopoese eine wichtige Rolle (Undi et al. 2013).

Die Lymphopoese ist ein Teil der Hämatopoese, bei dem sich die HSCs zu lymphoiden Progenitor-Zellen und schließlich zu B- oder T-Lymphozyten differenzieren. Die B-Zellreifung findet in zwei Stufen im Knochenmark und außerhalb des Knochenmarks statt, während die T-Zellreifung im Thymus abläuft. Es gibt eine ganze Reihe von microRNAs, die hierfür wichtig sind. Dazu zählen unter anderem microRNA-150 (miR-150) und miR-155. Bei der ebenfalls für die Lymphopoese wichtigen miR-181 ist die Expression in der frühen B-Zell-Differenzierung hoch, während sie mit zunehmender Differenzierung abnimmt. Die miR-181 spielt auch in der T-Zell-Entwicklung eine entscheidende Rolle (Chen et al. 2004) und kann bei der ALL hochreguliert sein (siehe Abschnitt 1.3.4). Das in dieser Arbeit näher untersuchte microRNA-Cluster 17-92 ist in B- und T-Vorläuferzellen stark exprimiert, wobei die Expression mit zunehmender Reifung der Zellen abnimmt. 
Fehlt es in Zellen, kommt es zur Störung der Entwicklung der B-Zellen im Anfangsstadium (pro-B zu prä-B-Stadium). Bei Überexpression des Clusters in Mäusen, entwickelten diese schwerwiegende lymphoproliferative Erkrankungen (Xiao et al. 2008).

Bei der Monozytopoese differenzieren im Knochenmark Granulozyten-MonozytenVorläuferzellen zu Promonozyten, die sich dann beim Übertritt ins Blut zu reifen Monozyten entwickeln. Nach achtstündiger Zirkulation verlassen sie das Blut und entwickeln sich im Gewebe zu gewebespezifischen Makrophagen. Verschiedene microRNAs spielen auch bei der Regulation von Monozyten und Makrophagen eine wichtige Rolle. So sind beispielsweise miR-21, miR-222, miR-23b, miR-24 und miR-27a während der Monozytendifferenzierung hochreguliert und miR-124 spielt eine Rolle bei der Aktivierung der Makrophagen (Conrad und Dittel 2011).

\subsection{4 microRNA-Expression bei ALL}

Eine Dysregulation von microRNAs wurde in vielen soliden Tumoren, aber auch in Leukämien entdeckt (Calin et al. 2004). Bei der Akuten Lymphatischen Leukämie (ALL) konnten Untersuchungen zeigen, dass die veränderte Expression einiger microRNAs zur Entwicklung der Leukämie beiträgt. Daher können microRNA-Expressions-Muster sowohl als Biomarker für die Diagnose und Differentialdiagnose, aber auch für Prognose und Therapie genutzt werden (Li Q et al. 2014).

Im Knochenmark von ALL-Patienten konnte eine geringere Expression von miR100, miR-196b und let-7e als in gesundem Knochenmark festgestellt werden, während miR-128a und miR-181, die für die Lymphopoese wichtig sind, überexprimiert waren (de Oliveira et al. 2012). B- und T-Zell-ALL lassen sich über die Expressionsmuster von miR148, miR-151 und miR-424 unterscheiden. Darüber hinaus lassen sich in verschiedenen Subtypen von B-ALL verschiedene microRNA-Expressionsmuster erkennen. Im Mausmodell konnten Mavrakis et al. (2011) zeigen, dass die microRNA-19b, -20a, -26a, -92 und -223 die Entstehung einer T-ALL fördern und die Mehrheit der microRNA-Expression in humaner T-ALL ausmachten. Von diesen microRNAs gehören miR-19b, miR-20a und 
miR-92 zum microRNA-Cluster 17-92, das in dieser Arbeit näher untersucht wurde.

Einige microRNAs, die an der Regulation von Zellproliferation und Apoptose beteiligt sind, können mit Onkogen- oder Tumor-Suppressor-Signalwegen interagieren und so zur Leukämieentstehung und Beeinflussung der Prognose von Patienten führen. So wurde beispielsweise von Ohyashiki et al. (2010) beschrieben, dass ALL-Patienten mit einer verstärkten Expression von miR-92a eine schlechte Prognose haben.

\section{4 microRNA-Cluster $17-92$}

Das microRNA-Cluster 17-92 (miR-17-92) wurde als potentielles Onkogen von Hayashita et al. (2005) identifiziert, da es in vielen hämato-onkologischen Erkrankungen verstärkt nachweisbar ist, so zum Beispiel beim Burkitt-Lymphom oder beim diffusen großzelligen B-Zell-Lymphom. Aus der pri-microRNA 17-92 entstehen sechs reife microRNAs: miR17, miR-18, miR-19a, miR-19b, miR-20 und miR-92 (Tanzer und Stadler 2004).

Das microRNA-Cluster 17-92 ist einerseits für die normale Entwicklung von Zellen notwendig, andererseits kann eine Dysregulation des Clusters maligne Veränderungen hervorrufen. Insgesamt können eine Proliferation, eine Hemmung der Zelldifferenzierung, eine Erhöhung der Angiogenese und ein vermehrtes Zellüberleben durch miR-17-92 hervorgerufen werden. Welche Funktion von den microRNAs in einer Zelle ausgeübt wird, ist vom Zelltyp und dem jeweiligen Entwicklungsstand der Zelle abhängig. So kann miR-1792 in Vorläufer-B-Zellen die Apoptose hemmen (Lu et al. 2005), während es in gesundem Lungengewebe die Vermehrung von Vorläuferzellen steigert (Suárez et al. 2008).

Die eigene Expression von miR-17-92 wird durch verschiedene Transkriptionsfaktoren (TFs) reguliert (Mogilyansky und Rigoutsos 2013). Als erster TF wurde c-myc identifiziert, der direkt am Genom von miR-17-92 bindet und seine Expression aktiviert (O’Donnell et al. 2005). Zusätzlich induzieren verschiedene TFs der E2F-Familie (z.B. E2F1, E2F2, E2F3) die Expression von miR-17-92 (Woods et al. 2007).

Eine der ersten Hinweise auf die Wirkung von miR-17-92 als Onkogen kam aus ei- 
nem in-vivo-Mausmodell zum B-Zell-Lymphom. In Mäusen, die nur eine Überexpression von c-myc, jedoch keine zusätzliche Überexpression von miR-17-19b (miR-17-92 ohne miR-92) aufwiesen, kam es erst nach längerer Zeit zu einem B-Zell-Lymphom. Beim Zusammenwirken des c-myc-Onkogens mit dem zusätzlich überexprimierten miR-17-19bCluster kam es hingegen zu einer beschleunigten Entstehung von B-Zell-Lymphomen. Eine Überexpression von miR-17-19b unterdrückte hierbei die c-myc induzierte Apoptose und verkürzte dadurch die Zeit bis zur Entstehung des Lymphoms. Zudem entstanden wesentlich aggressivere B-Zell-Lymphome (He et al. 2005).

Die biologische Funktion jeder einzelnen microRNA von miR-17-92 ist bislang nicht genau bekannt. Es ist jedoch aufgrund von Versuchen im Mausmodell vorstellbar, dass die einzelnen microRNAs spezifische, aber teilweise überlappende Funktionen haben (Ventura et al. 2008). Ein Hauptrolle bei der onkogenen Transformation von Zellen scheinen miR-19a und miR-19b zu spielen, denn wenn diese beiden microRNAs im Mausmodell mit c-myc überexprimierenden Mäusen mutiert waren, wurde die onkogen wirkende Zusammenarbeit von c-myc und miR-17-92 aufgehoben (Olive et al. 2009). Außerdem wurde festgestellt, dass das onkogene Zusammenwirken von c-myc und miR-17-92 signifikant stärker ist, wenn miR-92a deletiert oder in der seed-Region mutiert ist, als bei Überexpression von allen microRNAs von miR-17-92 (Olive et al. 2013).

Die durch miR-17-92 regulierten Gene sind vermutlich vielfältig. Bislang bekannte Zielgene von miR-17-92 in Lymphozyten sind PTEN und das Gen des proapoptotischen Proteins Bim, die durch miR-17-92 herunterreguliert werden, sodass es zu einer vermehrten Proliferation und verlängertem Zellüberleben kommt (Xiao et al. 2008).

Zielgene von miR-17 und miR-20 sind TFs der E2F-Klasse, unter anderem E2F1 (O’Donnell et al. 2005). Da E2F1 zusätzlich auch die Transkription von miR-17-92 aktiviert, handelt es sich anscheinend um eine negative Rückkopplung. Insgesamt hat der TF E2F1 duale Eigenschaften und kann einerseits als Tumorsuppressor, andererseits als Onkogen wirken. Bei zellullärem Stress wie DNA-Schädigungen vermittelt E2F1 die Apoptose der Zellen. In hochaggressiven chemotherapie-resistenten Tumoren wie dem 
malignen Melanom bewirkt E2F1 jedoch eine Tumorprogression, wobei der genaue Mechanismus bisher unbekannt ist (Knoll et al. 2013). Die miR-17 und miR-20 hemmen zudem den CDKN1A (cyclin-dependant-kinase-inhibitor), der auch als p21 bezeichnet wird. Er sorgt für einen verminderten Übergang von Zellen aus der G1 in die SynthesePhase des Zellzyklus und damit für eine verminderte Zellteilung (Olive et al. 2010).

Neueste Untersuchungen zeigen, dass in Mäusen die Überexpression von miR-17-92 in einer begrenzten Anzahl hämatopoetischer Zellen ausreicht, um B-Zell-Tumorerkrankungen zu entwickeln, sodass hierdurch noch einmal die Relevanz von miR-17-92 für die Tumorgenese unterstrichen wird (Danielson et al. 2015).

\subsection{Inhibition von microRNAs}

Bei vielen Krebserkrankungen ist eine Hochregulierung von verschiedenen microRNAs beschrieben. Die Inhibition von microRNAs scheint daher ein vielversprechender Ansatz zur Therapie von Tumorerkrankungen zu sein.

\subsubsection{Klassen von microRNA-Inhibitoren}

Generell gibt es verschiedene Möglichkeiten, microRNAs in einer Zelle zu hemmen. Eine Möglichkeit ist der Einsatz von antisense-microRNA-Oligonukleotiden (AMOs), die eine zur Ziel-microRNA komplementäre Sequenz aufweisen und so die microRNA direkt binden und hemmen. Hierbei gibt es 2'O-Methylgruppen-modifizierte AMOs, die im Vergleich zu den nicht modifizierten AMOs intrazellulär erheblich widerstandsfähiger gegen den Abbau durch Nukleasen sind und besser an die microRNAs binden (Hutvágner et al. 2004). Eine weitere Art von AMOs sind Antagomire. Dabei handelt es sich um 22 bis 23-Nukleotide lange 2'O-Methyl-modifizierte, 3'Ende-Cholesterol-konjugierte RNA-Analoga, die Nuklease-resistent sind (Scherr et al. 2007). Die Konjugation mit Cholesterol ermöglicht in vivo das Erreichen der Zielzelle ohne Einsatz eines Überträgermechanismus. Nachteile sind hohe benötigte Dosen und mögliche Nebenwirkungen 
(Krützfeldt et al. 2005). Auch Locked nucleic acids (LNAs) können als AMOs genutzt werden. Bei ihnen sind 2'-O und 4'-C der Ribose über eine Methylengruppe verbunden, sodass ein bizyklisches Nukleotid mit einer geschlossenen Struktur entsteht. Durch diese geschlossene Struktur wird die LNA/mRNA-Verbindung stabilisiert und resistent gegen Abbau durch Nukleasen (Kaur et al. 2006).

Die durch AMOs erzielten Effekte in Zellen werden in der Literatur unterschiedlich bewertet. So wurde von Thum et al. (2008) ein Effekt eines miR-21-Antagomirs auf Herzerkrankungen in Mäusen beschrieben, während von Patrick et al. (2010) kein Effekt eines miR-21-Inhibitors bei Mäusen gezeigt werden konnte. Diese Unterschiede könnten durch hohe Konzentrationen der Inhibitoren in den Zellen verursacht sein, die dadurch unspezifische Effekte in der Genexpression hervorrufen. Ebenfalls könnte die Technik der Einbringung von Inhibitoren eine Rolle spielen, denn die bei den Mäusen verwendete Technik der Schwanzveneninjektion könnte die Verteilung und Metabolisierung des Inhibitors behindern oder eine Toxizität hervorrufen (Zhang et al. 2012).

Neben AMOs gibt es microRNA-Schwämme, die längerfristig microRNAs hemmen. Sie enthalten multiple Bindungsstellen, die komplementär zu microRNAs sind und über die sie diverse microRNAs gleichzeitig binden und hemmen können.

Insgesamt ist die Einbringung eines microRNA-Inhibitors in eine Zelle die größte Schwierigkeit bei der Behandlung von Zellen mit microRNA-Inhibitoren. Auf die verschiedenen Möglichkeiten der Einbringung wird im nächsten Unterabschnitt eingegangen.

\subsubsection{Methoden zum Einbringen von microRNA-Inhibitoren in Zellen}

Das Einbringen von fremder DNA oder RNA in eine Zelle wird als Transfektion bezeichnet. Man unterscheidet bei der Transfektion physikalische, chemische und biologische Methoden.

Als physikalische Methoden sind Mikroinjektion, optische Transfektion, Elektroporation, Sonoporation, Magnetofektion und molekulare Vibrationen durch ein elektrisches 
Feld bekannt. Bei der Mikroinjektion und optischer Transfektion kann jeweils nur eine Zelle zur Zeit transfiziert werden, sodass die Verfahren aufwendig, aber mit einer sehr hohen Transfektionsrate verbunden sind (Kaestner et al. 2015). Bei der Elektroporation werden mittels elektrischer Impulse Poren in der Zellmembran erzeugt, um DNA oder RNA in die Zielzelle zu bekommen. Dieses Verfahren kann jedoch zu unterschiedlichen Mengen von Nukleinsäuren in den einzelnen Zellen führen und viele Zellen schädigen (Zhang et al. 2012). Ein allgemeiner Vorteil der physikalischen Methoden ist, dass sie nicht von chemischen oder biologischen Eigenschaften der zu transfizierenden Zellen abhängen.

Bei den chemischen Transfektionsmethoden wird der Transport der DNA oder RNA durch die Zellmembran mit Hilfe von Calcium-Phosphaten, Dendrimeren oder kationischen Lipiden beschleunigt. Die Calcium-Phosphat-Methode ist sehr kostengünstig, aber die Transfektionsrate ist gering. Primärzellen und Zellen in Suspensionskulturen können mit dieser Methode kaum transfiziert werden (Kingston et al. 2001). Dendrimere sind positiv geladen, binden an die negativ gelandenen Phosphate der DNA oder RNA und der insgesamt positive Komplex wird in die Zelle aufgenommen. Sie werden oft in Kombination mit Lipofektion zur Transfektion genutzt (Shcharbin et al. 2013). Bei der Lipofektion oder liposomalen Transfektion bilden kationische Lipide Vesikel und binden die DNA oder RNA. Diese insgesamt positiv geladenen Komplexe lagern sich an die Zellmenbran an und werden so in die Zelle aufgenommen. Die kationischen Lipide bestehen aus einer positiv gelandenen Gruppe, mit der über eine Verbindungsgruppe ein oder zwei hydrophobe Lipid-Ketten verbunden sind. Zusammen mit weiteren neutralen Lipiden bilden sich uni-lamellare Transfektionskomplexe, die Liposomen, die eine positive Oberfläche in wässriger Lösung haben. Durch diese positive Oberflächenladung wird die Interaktion der Liposomen mit der Zellmembran vermittelt und das Liposom mit der enthaltenen DNA oder RNA kann in die Zelle aufgenommen werden (Kaestner et al. 2015). Es handelt sich hierbei um ein einfaches und schnelles Verfahren, das gut reproduzierbar ist und im Vergleich zu anderen chemischen Transfektionsmethoden eine 
verhältnismäßig hohe Transfektionsrate aufweist. Daher gehört es zu den verbreitetsten Transfektionsmethoden und wurde auch in der vorliegenden Arbeit verwendet.

In den meisten ausdifferenzierten Primärzellen, wie beispielsweise adulten Kardiomyozyten, ist Lipofektion als Transfektionsmethode nicht erfolgreich. Hier können biologische Methoden zum Einsatz kommen, wobei Viren als Überträger/Vektoren verwendet werden. In Frage kommen Adenoviren, die sich jedoch nicht ins Wirtsgenom integrieren können und in vivo häufig eine Immunantwort hervorrufen (Bessis et al. 2004). Adenoassoziierte Viren, die zu den nicht pathogenen Parvoviren zählen, hingegen lösen in der Regel keine Immunantwort aus und werden über rezeptor-vermittelte Endozytose in die Zellen aufgenommen (Müller et al. 2008). Auch Retroviren inklusive Lentiviren können als Vektoren dienen und sich ins Wirtsgenom integrieren.

\subsubsection{Inhibition von microRNAs in klinischen Studien}

Die Inhibition von microRNAs ist im letzten Jahrzehnt soweit voran geschritten, dass mittlerweile erste klinische Studien zu microRNA-Inhibitor-basierten Medikamenten vorliegen. So gibt es eine Möglichkeit die chronische Hepatitis C mit einem micro-RNAInhibitor zu behandeln. Es handelt sich dabei um den microRNA-Inhibitor-122 (Handelsname Miravirsen), der als LNA-AMO die leberspezifische microRNA-122 bindet und damit an ihrer Funktion hindert. Die Stabilität und Vermehrungsfähigkeit des Hepatitis C-Virus ist dabei von der Interaktion zwischen HCV-Genom und miR-122 abhängig. Getestet wurde Miravirsen in einer doppelblinden, placebokontrollierten und randomisierten Phase-IIa-Studie an 36 Patienten mit chronischer Hepatitis C des Genotyps 1, die bislang keine Therapie der Hepatitis C erhalten hatten. Die fünfmalige Gabe von verschiedenen Dosierungen an Miravirsen erfolgte wöchentlich subkutan über einen Zeitraum von 29 Tagen. Es konnte durch die Gabe von Miravirsen eine dosisabhängige Reduktion der HCV-RNA-Menge, auch über das Ende der Miravirsen-Gabe hinaus, festgestellt werden. Dabei wurden keine Dosis-limitierenden Effekte oder Behandlungunterbrechungen und keine Todesfälle durch Miravirsen festgestellt (Janssen et al. 2013). Darüber hinaus 
wurde bei diesen 36 Patienten wie schon bei Untersuchungen von Primaten (Lanford et al. 2010) kein Hinweis auf virale Resistenzen gegen Miravirsen gefunden. Bei der Bindungsstelle der miR-122 für das HCV-Genom handelt es sich um eine hochkonservierte Sequenz, sodass Miravirsen potentiell bei allen HCV-Genotypen genutzt werden könnte (Li et al. 2011). Im Mausmodell konnte von Esau et al. (2006) zudem gezeigt werden, dass die Inhibtion von miR-122 zu einer Veringerung der Steatosis hepatis bei ernährungsbedingtem Übergewicht führte, sodass anti-miR-122 auch eine Option für die Behandlung der nicht-alkoholbedingten Fettleber sein könnte. Insgesamt konnte damit eine gute Wirksamkeit von anti-miR-122/Miravirsen bei Patienten mit chronischer Hepatitis $\mathrm{C}$ festgestellt werden.

Ein zweiter potentieller microRNA-Inhibitor wird derzeit in einer randomisierten, doppelblinden, plazebokontrollierten Phase-I-Studie in den USA untersucht. Nach den Informationen des Herstellers Regulus Therapeutics handelt es sich bei RG-012 um einen Inhibitor der microRNA-21. Untersucht wird RG-012 für Patienten mit Alport-Syndrom, bei dem es sich um eine progrediente Erkrankung der Nieren handelt, für die es bislang lediglich wenige symptomatische Therapieoptionen gibt. Die miR-21 trägt zur Pathogenese von fibrotischen Erkrankungen in vielen Organen, auch der Niere, bei, indem miR-21 für die Energiegewinnung der Zellen nötige Stoffwechselwege hemmt (McClelland et al. 2015). Wurden Mäuse mit Alport-Nephropathie mit anti-miR-21 subkutan behandelt, kam es zu einem deutlich milderen Verlauf der Nierenerkrankung als bei mit Plazebo behandelten Mäusen ohne einen Nachweis von Nebenwirkungen. Im Mausmodell konnte daher gezeigt werden, dass die Inhibition von miR-21 als Therapie für Patienten mit chronischer Nierenerkrankung, z.B. Alport-Syndrom, in Frage kommt (Gomez et al. 2015). In der genannten Phase-I-Studie soll nun im ersten Schritt die Verträglichkeit von RG-012 bei gesunden Freiwilligen untersucht werden.

Für die in dieser Arbeit näher betrachtete akute lymphatische Leukämie liegen nach Kenntnisstand der Autorin bisher weder im klinischen noch im präklinischen Rahmen Studien zur Wirkung von microRNA-Inhibitoren vor. 


\subsubsection{Inhibition des microRNA-Clusters 17-92}

Bei vielen Tumoren ist eine Hochregulierung von verschiedenen microRNAs bekannt. Eine Überexpression des in dieser Arbeit näher untersuchten microRNA-Clusters 1792 ist dabei beim Burkitt-Lymphom, bei Leukämien, aber auch bei anderen Tumorarten nachweisbar. Eine Hemmung könnte daher ein vielversprechender therapeutischer Ansatz bei Tumorerkrankungen sein.

Von He et al. (2005) wurde beschrieben, dass eine Überexpression von miR-17-92 an der Entwicklung von B-Zell-Lymphomen und Lungenkrebs beteiligt ist. Daher wurde versucht dieses microRNA-Cluster mit AMOs zu inhibieren. Durch anti-miR-17 und anti-miR-20a konnte eine verstärkte Apoptose in miR-17-92 überexprimierenden Lungenkrebszelllinien erzielt werden. Anti-miR-18a und anti-miR-19a führten hingegen zu keinem sichtbaren inhibitorischen Effekt, während anti-miR-92 nur zu einer geringen Reduktion des Zellwachstums führte (Matsubara et al. 2007).

Eine Inhibition des microRNA-Clusters 17-92 durch Lentivirus-vermittelte Transfektion von Antagomirs in Zelllinien wurde durch Scherr et al. (2007) untersucht. Die funktionelle Hemmung von miR-18a, miR-19b und miR-20a mit dem entsprechenden Antagomir zeigte sich durch eine verstärkte Expression von assoziierten Genen in Zelllinien. So war die Proteinexpression von E2F1 (miR-20 Zielgen, siehe Abschnitt 1.4) erhöht, wenn anti-miR-20a in die K562-Zelllinie eingebracht wurde, während eine Überexpression von miR-20a zu einer Reduktion der E2F1-Konzentration führt. Durch Einschleusung von anti-miR-18a alleine, aber nicht durch anti-miR-19b, anti-miR-20a oder AntagomirKontrolle wurde das Wachstum der K562-Zelllinie gehemmt. Wurde zusätzlich zu antimiR-18a miR-17-19b in die Zelllinie eingeschleust, so wurde die wachstumshemmende Wikung von anti-miR-18a auf die Zelllinie verhindert. Hierdurch werden noch einmal die verschiedenen Funktionen der einzelnen microRNAs von miR-17-92 deutlich.

Medulloblastome sind die häufigsten malignen Gehirntumoren bei Kindern. Eine Untergruppe ist durch die konstitutive Aktivierung des Sonic Hedgehog (SHH) Signalwegs 
charakterisiert. Beim SHH-Medulloblastom wurde sowohl im Mausmodell als auch im Menschen eine erhöhte Expression von microRNAs des miR-17-92-Clusters nachgewiesen. Daher wurde von Murphy et al. (2013) das therapeutische Potential von LNA-AMOs für die Hemmung von miR-17-92 in zwei Mausmodellen zum SHH-Medulloblastom untersucht. Die Medulloblastomzellen nahmen die LNA-AMOs passiv auf und es kam zu einer spezifischen Hemmung der Ziel-microRNAs. Anti-miR-17 und anti-miR-19 führten in vitro zu einem reduzierten Tumorzellwachstum. Die systemische Behandlung von Mäusen mit anti-miR-17 und anti-miR-19 führte zu einem reduzierten Tumorwachstum in vivo und verlängertem Überleben der Mäuse. Daher könnte die Inhibition des miR-17-92-Clusters mit LNA-anti-miRs eine Behandlungsoption für Patienten mit SHHMedulloblastom sein.

Sharifi et al. (2014) untersuchten die Inhibition von miR-92a in der Akuten Promyelozytenleukämie(APL)-Zelllinie HL-60 mit einem LNA-AMO. Die Untersuchung zeigte eine starke Reduktion der Zellviabilität und eine Induktion der Apoptose. Diese Erkenntnisse könnten eine Möglichkeit für einen Therapieansatz der APL darstellen.

Zusammengefasst lässt sich die Wirkung eines microRNA-Inhibitors gegen das überexprimierte miR-17-92-Cluster durch eine Erhöhung der Apoptoserate erkennen. Dies wurde in der vorliegenden Arbeit zur Quantifizierung der anti-miR-Wirkung genutzt.

\subsection{Ziele der Arbeit}

Eine verstärkte Expression des microRNA-Clusters 17-92 führt, wie in Abschnitt 1.4 beschrieben, zu einer verstärkten Proliferation und einer verringerten Apoptoserate von Zellen. Eine Hauptrolle scheint dabei miR-19 zu spielen. Dementsprechend stellte sich die Frage, ob durch die Einschleusung eines microRNA-Inhibitors gegen miR-19 eine Erhöhung der Apoptoserate von Zellen zu erreichen ist. Dies wurde anhand von zwei humanen Zelllinien überprüft: Bei der Jurkat-Zelllinie handelte es sich um T-ALL-Zellen, während die SU-DHL-4-Zelllinie aus einem B-Zell-Lymphom hervorgegangen war. Beide 
Zelllinien wurden mit dem microRNA-Inhibitor 19b transfiziert. Dies erfolgte mittels chemischer Transfektion mit kationischen Lipiden (liposomale Transfektion). Um den Effekt des Inhibitors zu messen, wurde nach mehrtägiger Inkubation die Apoptoserate der transfizierten Zellen mittels Annexin V-Färbung und Durchflusszytometrie im Vergleich zu unbehandelten Zellen bestimmt.

Um zu testen, welche Auswirkungen die Transfektion mit dem microRNA-Inhibitor 19b auf humane Primärzellen hat, wurden in dieser Arbeit auch mononukleäre Zellen aus Buffy Coats von gesunden Blutspendern untersucht. Hierzu erfolgte eine Aufreinigung der Buffy Coats durch eine Trenn-Lösung zur Isolierung von mononukleären Zellen. Diese mononukleären Zellen wurden anschließend ebenfalls mit dem microRNA-Inhibitor 19b transfiziert und nach mehrtägiger Inkubation auch hier die Apoptoserate bestimmt. Da es sich bei den mononukleären Zellen um eine Mischung verschiedener Leukozytenarten handelt, wurde zusätzlich untersucht, ob sich T-Lymphozyten, B-Lymphozyten und Monozyten hinsichtlich ihrer Aufnahme des microRNA-Inhibitors 19b (Transfektionsrate) und ihrer Apoptoserate und damit ihrer Reaktion auf den microRNA-Inhibitor 19b unterscheiden. Hiermit sollte ein erster Eindruck gewonnen werden, welche Erfolgschancen und Nebenwirkungen von einem Inhibitor der miR-19b bei humanen Primärzellen zu erwarten sind. 


\section{$2 \quad$ Material und Methoden}

\subsection{Arbeitsmaterialien und Reagenzien}

Die nachfolgenden tabellarischen Aufstellungen geben eine Übersicht über alle in der vorliegenden Arbeit eingesetzten Arbeitsmaterialien und Reagenzien. Die in dieser Arbeit verwendeten Buffy Coats wurden aus der Vollblutspende der Abteilung Transfusionsmedizin der Universitätsmedizin Göttingen bezogen. Vor Durchführung der Versuche wurde ein Ethikantrag gestellt und ein positives Votum eingeholt (DOK_300_2015).

Tabelle 2.1: Nährmedien

\begin{tabular}{ll}
\hline Bezeichnung & Inhaltstoffe \\
\hline \hline RPMI-Medium I & RPMI-Medium 1640 (1X) + GlutaMAX $^{\mathrm{TM}}$ mit 20\% Fetal \\
& Bovine Serum (FBS) und 1\% Penicillin/Streptomycin (Pen \\
& Strep) \\
\hline RPMI-Medium II & RPMI-Medium $1640(1 \mathrm{X})+$ GlutaMAX $^{\mathrm{TM}}$ mit $10 \%$ Fetal \\
& Bovine Serum (FBS) und 1\% Penicillin/Streptomycin (Pen \\
& Strep) \\
\hline RPMI-Medium III & $100 \%$ RPMI-Medium $1640(1 \mathrm{X})+$ GlutaMAX $^{\mathrm{TM}}$ \\
\hline MEM-Medium & 100\% OPTI-MEM ${ }^{\circledR}(1 \mathrm{X})+$ GlutaMAX $^{\mathrm{TM}}$ Reduced Serum \\
& Medium \\
\hline
\end{tabular}

Die Bezeichnung MEM steht für „minimum essential medium“ 
Tabelle 2.2: Glas- und Plastikmaterialien

\begin{tabular}{|c|c|c|}
\hline Bezeichnung & Material & Hersteller \\
\hline Zellschaber & Cell Scraper $25 \mathrm{~cm}$ & $\begin{array}{l}\text { Sarstedt, Newton } \\
\text { (USA) }\end{array}$ \\
\hline 50-ml-Reaktionsgefäß & Cellstar-Tubes $50 \mathrm{ml}$ & $\begin{array}{l}\text { Greiner Bio-One } \\
\text { GmbH, Frickenhausen }\end{array}$ \\
\hline 2-ml-Reaktionsgefäß & Cryo.s $^{\mathrm{TM}} 2 \mathrm{ml}$ Sample Storage Tubes & $\begin{array}{l}\text { Greiner Bio-One } \\
\text { GmbH, Frickenhausen }\end{array}$ \\
\hline Eppendorfgefäß & $\begin{array}{l}\text { Eppendorf Safe-Lock-Tubes } 1,5 \mathrm{ml}, \\
2 \mathrm{ml}\end{array}$ & $\begin{array}{l}\text { Eppendorf, } \\
\text { Wesseling-Berzdorf }\end{array}$ \\
\hline FACS-Röhrchen & $\begin{array}{l}\text { FACS-Röhrchen } 5 \mathrm{ml} \text { Polystyrene } \\
\text { Round-Bottom-Tube }\end{array}$ & Falcon, Durham (USA) \\
\hline Zählkammer & $\begin{array}{l}\text { Neubauer-improved Zählkammer } \\
\text { Assistent }{ }^{\circledR}\end{array}$ & $\begin{array}{l}\text { Glaswarenfabrik Karl } \\
\text { Hecht, Sondheim v.d. } \\
\text { Rhön }\end{array}$ \\
\hline Glaspasteurpipetten & Pasteurpipetten $150 \mathrm{~mm}$ & $\begin{array}{l}\text { Brand GmbH \& Co. } \\
\text { KG, Wertheim }\end{array}$ \\
\hline Multipipettenspitzen & $\begin{array}{l}\text { Eppendorf-Combitips advanced } 5 \mathrm{ml}, \\
10 \mathrm{ml} \text { für Multipipette }\end{array}$ & Eppendorf, Hamburg \\
\hline Pipettenspitzen & $\begin{array}{l}\text { Pipettenspitzen } 10 / 20 \mu l, 100 \mu l, \\
1000 \mu l \text { TipOne Filter Tip (sterile) }\end{array}$ & Starlab, Hamburg \\
\hline Pipettenspitzen & $\begin{array}{l}\text { Pipettenspitzen } 2,5 \mu \mathrm{l} \\
\text { SafeSeal-Tips }{ }^{\circledR} \text { Premium }\end{array}$ & $\begin{array}{l}\text { Biozym, Hessisch } \\
\text { Oldendorf }\end{array}$ \\
\hline Serologische Pipetten & Serological pipets $5 \mathrm{ml}, 10 \mathrm{ml}, 25 \mathrm{ml}$ & $\begin{array}{l}\text { Falcon, Franklin Lakes } \\
\text { (USA) }\end{array}$ \\
\hline $\begin{array}{l}25-\mathrm{cm}^{2}- \\
\text { Zellkulturflaschen }\end{array}$ & Zellkulturflaschen CytoOne ${ }^{\circledR}, 25 \mathrm{~cm}^{2}$ & Starlab, Hamburg \\
\hline $\begin{array}{l}\text { 75-cm }{ }^{2}- \\
\text { Zellkulturflaschen }\end{array}$ & Zellkulturflaschen $75 \mathrm{~cm}^{2}$ & $\begin{array}{l}\text { Greiner Bio-One } \\
\text { GmbH, Frickenhausen }\end{array}$ \\
\hline $\begin{array}{l}\text { 6-Loch- } \\
\text { Zellkulturplatten }\end{array}$ & $\begin{array}{l}\text { Zellkulturplatten, multi-Well-Platte, } \\
6 \text {-Well }\end{array}$ & $\begin{array}{l}\text { Greiner Bio-One } \\
\text { GmbH, Frickenhausen }\end{array}$ \\
\hline $\begin{array}{l}\text { 12-Loch- } \\
\text { Zellkulturplatten }\end{array}$ & $\begin{array}{l}\text { Zellkulturplatten Nunclon }{ }^{\mathrm{TM}} \Delta \\
\text { Surface, 12-Well }\end{array}$ & $\begin{array}{l}\text { Nunc, Roskilde } \\
\text { (Dänemark) }\end{array}$ \\
\hline
\end{tabular}


Tabelle 2.3: Laborgeräte

\begin{tabular}{|c|c|c|}
\hline Bezeichnung & Gerät & Hersteller \\
\hline Inkubator & Inkubator HERA cell ${ }^{\circledR}$ & Heraeus, Hanau \\
\hline Computer & $\begin{array}{l}\text { PC mit folgender Software: BD } \\
\text { FACSDiva }\end{array}$ & $\begin{array}{l}\text { BD Biosciences, } \\
\text { Franklin Lakes (USA) }\end{array}$ \\
\hline Durchflusszytometer & BD FACSCanto ${ }^{\text {TM }}$ II Flow Cytometer & $\begin{array}{l}\text { BD Biosciences, } \\
\text { Franklin Lakes (USA) }\end{array}$ \\
\hline Durchlichtmikroskop & Lichtmikroskop Axiostar & Zeiss, Jena \\
\hline Einfrierbehälter & $\begin{array}{l}\text { NALGENE }{ }^{\mathrm{TM}} \text { Cryo } 1{ }^{\circ} \mathrm{C} \text { Freezing } \\
\text { Container }\end{array}$ & $\begin{array}{l}\text { Nalge Nunc } \\
\text { International, } \\
\text { Rochester (USA) }\end{array}$ \\
\hline $\begin{array}{l}\text { Inverses } \\
\text { Auflichtmikroskop }\end{array}$ & Lichtmikroskop Axiovert 25 & Zeiss, Jena \\
\hline Multipipette & Eppendorf Multipipette plus & $\begin{array}{l}\text { Eppendorf, } \\
\text { Wesseling-Berzdorf }\end{array}$ \\
\hline Pipette & 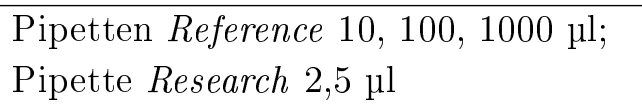 & $\begin{array}{l}\text { Eppendorf, } \\
\text { Wesseling-Berzdorf }\end{array}$ \\
\hline Sterilbank & $\begin{array}{l}\text { Microflow biological safety cabinet } \\
\text { MDH } 51426\end{array}$ & $\begin{array}{l}\text { Nalge Nunc } \\
\text { International, } \\
\text { (USA/Dänemark) }\end{array}$ \\
\hline Tischzentrifuge & STRATAGENE $^{\circledR}$ ProFuge $^{\text {TM }} 10 \mathrm{~K}$ & $\begin{array}{l}\text { Stratagene California, } \\
\text { La Jolla (USA) }\end{array}$ \\
\hline Vakuumpumpe & LABOPORT ${ }^{\circledR}$ N86 KN.18 & $\begin{array}{l}\text { KNF, Village-Neuf } \\
\text { (Frankreich) }\end{array}$ \\
\hline Vortexer & Vortexer Typ VF 2 & $\begin{array}{l}\text { IKA }{ }^{\circledR} \text {-Werke GmbH \& } \\
\text { CO. KG, Staufen }\end{array}$ \\
\hline Wasserbad & Wasserbad Typ 3042 & Köttermann, Hänigsen \\
\hline Zentrifuge & Rotanta $46 \mathrm{RS}$ & Hettich,Tuttingen \\
\hline
\end{tabular}

Tabelle 2.4: microRNAs

Alle microRNAs wurden von der Firma Exiqon (Vedbaek, Dänemark) bezogen.

\begin{tabular}{ll}
\hline microRNA & Sequenz \\
\hline \hline miRCURY LNA ${ }^{\mathrm{TM}}$ Power & $5^{\prime}-3^{\prime} / 56-\mathrm{FAM} / \mathrm{TAACACGTCTATACGCCCA}$ \\
Inhibitor Control, Negative & \\
Control A & \\
\hline miRCURY LNA & \\
Inhibitor, hsa-miR-19b-3p & $5^{\prime}-3^{\prime} / 56-$ FAM/CAGTTTTGCATGGATTTGCAC \\
\hline
\end{tabular}


Tabelle 2.5: Reagenzien

\begin{tabular}{|c|c|c|}
\hline Bezeichnung & Substanz & Hersteller \\
\hline 2-Propanol & 2-Propanol & Merck, Darmstadt \\
\hline 7-AAD-Lösung & 7-AAD Viability Staining Solution & $\begin{array}{l}\text { BioLegend, San Diego } \\
\text { (USA) }\end{array}$ \\
\hline Annexin V-Puffer & Annexin V Binding Buffer & $\begin{array}{l}\text { BioLegend, San Diego } \\
\text { (USA) }\end{array}$ \\
\hline Annexin V-Antikörper & $\begin{array}{l}\text { anti-human Annexin V Pacific } \\
\text { Blue }^{\text {TM }}\end{array}$ & $\begin{array}{l}\text { BioLegend, San Diego } \\
\text { (USA) }\end{array}$ \\
\hline CD3-Antikörper & anti-human CD3 PE & $\begin{array}{l}\text { BioLegend, San Diego } \\
\text { (USA) }\end{array}$ \\
\hline CD14-Antikörper & anti-human CD14 PE & $\begin{array}{l}\text { BioLegend, San Diego } \\
\text { (USA) }\end{array}$ \\
\hline CD19-Antikörper & anti-human CD19 PE & $\begin{array}{l}\text { BioLegend, San Diego } \\
\text { (USA) }\end{array}$ \\
\hline CD45-Antikörper & anti-human CD45 APC & $\begin{array}{l}\text { BioLegend, San Diego } \\
\text { (USA) }\end{array}$ \\
\hline Destilliertes Wasser & Aqua dest. & B. Braun, Melsungen \\
\hline DMSO & Dimethylsulphoxid 99,5\% & $\begin{array}{l}\text { Sigma-Aldrich, } \\
\text { Steinheim }\end{array}$ \\
\hline Ethanol & $\begin{array}{l}\text { Alkopharm } 80,80 \% \text { Ethanol, } 20 \% \\
\text { Ethylmethylketon }\end{array}$ & $\begin{array}{l}\text { Brüggemann Alcohol, } \\
\text { Heilbronn }\end{array}$ \\
\hline FBS & Fetal Bovine Serum, heat inactivated & $\begin{array}{l}\text { Gibco by Life } \\
\text { Technologies }\end{array}$ \\
\hline MACS-Puffer & $\begin{array}{l}\text { autoMACS }{ }^{\mathrm{TM}} \text { Running Buffer, } \\
\text { MACS Separation Buffer }\end{array}$ & $\begin{array}{l}\text { Macs Miltenyi Biotec, } \\
\text { Bergisch Gladbach }\end{array}$ \\
\hline Natriumcitrat-Lösung & $\begin{array}{l}73,525 \mathrm{~g} \text { Tri-Natrium-Dihydrat in } \\
1 \text { Liter destilliertem Wasser }\end{array}$ & Merck und B. Braun \\
\hline Trenn-Lösung & $\begin{array}{l}\text { Ficoll-Paque }{ }^{\mathrm{TM}} \text { PLUS endotoxin } \\
\text { tested }\end{array}$ & $\begin{array}{l}\text { GE Healthcare } \\
\text { Bio-Sciences AB, } \\
\text { Uppsala (Schweden) }\end{array}$ \\
\hline PBS & $\begin{array}{l}\text { Phosphate Buffered Saline pH } 7.4 \\
{[-] \mathrm{CaCl}_{2},[-] \mathrm{MgCl}_{2}}\end{array}$ & $\begin{array}{l}\text { Gibco by Life } \\
\text { Technologies }\end{array}$ \\
\hline PenStrep & Penicillin/Streptomycin & $\begin{array}{l}\text { Gibco by Life } \\
\text { Technologies }\end{array}$ \\
\hline RNase & RNase ZAP & $\begin{array}{l}\text { Sigma-Aldrich, St. } \\
\text { Louis (USA) }\end{array}$ \\
\hline $\begin{array}{l}\text { Tri-Natriumcitrat- } \\
\text { Dihydrat }\end{array}$ & Tri-Natriumcitrat-Dihydrat & Merck, Darmstadt \\
\hline Puffer-Lösung & $\begin{array}{l}\text { Tris-EDTA-Puffer-Lösung, } 10 \mathrm{mM} \\
\text { Tris-HCl, } 1 \mathrm{mM} \text { disodium EDTA, pH } \\
8.0\end{array}$ & $\begin{array}{l}\text { Sigma-Aldrich, } \\
\text { Steinheim }\end{array}$ \\
\hline
\end{tabular}


Tabelle 2.6: Transfektionsreagenzien

\begin{tabular}{lll}
\hline Bezeichnung & Reagenz & Hersteller \\
\hline \hline HiPerfect & HiPerfect ${ }^{\circledR}$ Transfection & Qiagen, Venlo (Niederlande) \\
& Reagent & \\
\hline Lipofectamine & Lipofectamine ${ }^{\circledR}$ RNAiMAX & Life Technologies GmbH, \\
& Reagent & Darmstadt \\
\hline siLentFect & siLentFect $^{\text {TM }}{ }^{\text {Lipid Reagent }}$ & Bio-Rad Laboratories, Hercules \\
& & (USA) \\
\hline
\end{tabular}

Tabelle 2.7: Zelllinien

\begin{tabular}{llll}
\hline Bezeichnung & Zellart & DSMZ no. & Hersteller \\
\hline \hline Jurkat-Zellen & humane T-Zell-Leukämielinie & ACC 282 & DSMZ, Braunschweig \\
\hline SU-DHL-4-Zellen & humane B-Zell-Lymphomlinie & ACC 495 & DSMZ, Braunschweig \\
\hline
\end{tabular}

\subsection{Bestimmung der Apoptose- und Transfektionsrate}

Für die Untersuchung der Wirkung des microRNA-Inhibitors 19b auf verschiedene Zellarten galt es, zwei entscheidende Fragen zu klären: Zum einen musste untersucht werden, inwieweit eine Aufnahme des microRNA-Inhibitors in die eingesetzten Zellen möglich war (Transfektionsrate), zum anderen, ob die Aufnahme des microRNA-Inhibitors 19b zu einer verstärkten Apoptose der transfizierten Zellen führte (Apoptoserate).

Für die Bestimmung der Transfektionsrate wurden in dieser Arbeit ausschließlich fluoreszenzmarkierte microRNAs eingesetzt. Dementsprechend war jede mit einer microRNA transfizierte Zelle in der Durchflusszytometrie über die Farbstoffmarkierung erkennbar und die Transfektionsrate somit als Anteil der fluoreszenzmarkierten Zellen bestimmbar. Die Apoptoserate der Zellen wurde ermittelt, indem die apoptotischen Zellen selektiv mit dem Farbstoff Annexin V angefärbt wurden. Die Messung der Apoptose- und Transfektionsraten erfolgte mit dem Durchflusszytometer BD FACSCanto ${ }^{\mathrm{TM}}$ II Flow Cytometer der Firma BD Biosciences (USA). Die jeweilige Probe wurde optisch auf Aggregate geprüft und anschließend in das Durchflusszytometer eingespannt. Insgesamt wurden für jede nachfolgend durchgeführte Messung 50.000 Zellen analysiert. 


\subsection{Generelle Informationen zu Versuchsbedingungen}

Wenn nicht anders angegeben, wurden die nachfolgend beschriebenen Zentrifugationen bei $20^{\circ} \mathrm{C}$ und einer Beschleunigung und Bremse von $\mathrm{R}=9$ durchgeführt. Die Inkubation bei $37{ }^{\circ} \mathrm{C}$ erfolgte im Inkubator bei $5 \% \mathrm{CO}_{2}$. Vor Einbringen von Materialien in die

Sterilbank wurden diese mit Ethanol abgesprüht. Das Absaugen der Überstände erfolgte mit einer Vakuumpumpe unter Benutzung der Glaspasteurpipetten. Werden nachfolgend Zellzahlen angegeben oder diese als Bestandteil der Probenvorbereitung bestimmt, so erfolgte dies mit dem Durchlichtmikroskop unter Verwendung einer Neubauer-Zählkammer. Die Zelldichte wurde immer mit dem inversen Auflichtmikroskop kontrolliert.

\section{$2.4 \quad$ Vorbereitung der Zellkulturen}

\subsubsection{Kultivierung, Vermehrung und Kryokonservierung von Jurkat- und SU-DHL-4-Zellen}

Die in dieser Arbeit eingesetzten Jurkat- und SU-DHL-4-Zellen wurden von der Deutschen Sammlung von Mikroorganismen und Zellkulturen GmbH in Braunschweig bezogen. Laut den mitgelieferten Unterlagen wurden beide Zelllinien negativ auf Mykoplasmen, EBV, HBV, HCV, HIV, HTLV-I und -II und SMRV getestet. Die Jurkat-Zelllinie wurde zusätzlich negativ auf HHV-8 getestet.

Bei der Jurkat-Zelllinie handelte es sich um eine humane T-Zell-Leukämie-Linie, die 1976 aus dem peripheren Blut eines 14-jährigen Jungen mit dem 1. Rezidiv einer akuten lymphatischen Leukämie entnommen wurde. Die zweite Zelllinie SU-DHL-4 war eine humane B-Zell-Lymphom-Linie, die 1975 aus dem Aszites eines 38-jährigen Mannes mit B-Zell-Non-Hodkin-Lymphom gewonnen wurde. Beide Zelllinien wurden im gefrorenen Zustand geliefert und als Suspensionskulturen kultiviert.

Zunächst mussten beide Zelllinien aufgetaut, vermehrt und kryokonserviert werden. Für den Auftauprozess der jeweiligen Zelllinie wurde unter der Sterilbank $20 \mathrm{ml}$ auf 
$37^{\circ} \mathrm{C}$ erwärmtes RPMI-Medium I in ein 50-ml-Reaktionsgefäß überführt. Ein 2-mlReaktionsgefäß mit gefrorenen Jurkat- oder SU-DHL-4-Zellen wurde bei $37{ }^{\circ} \mathrm{C}$ im Wasserbad so lange erwärmt bis der Inhalt flüssig war. Nach dem Auftauen wurden die Zellen sofort unter der Sterilbank in das vorgelegte RPMI-Medium I überführt. Die erhaltene Lösung wurde anschließend mit $200 g$ für fünf Minuten zentrifugiert und der Überstand unter der Sterilbank abgesaugt. Das verbleibende Zellpellet wurde mit $1 \mathrm{ml}$ vorgewärmtem RPMI-Medium I resuspendiert und in eine $25-\mathrm{cm}^{2}$-Zellkulturflasche mit insgesamt ca. $5 \mathrm{ml}$ RPMI-Medium I gegeben. Die Zellzahl in der Zellkulturflasche wurde anschließend bestimmt und gegebenenfalls weiteres RPMI-Medium I zugegeben, so dass pro Milliliter RPMI-Medium I etwa $1 \times 10^{6}$ Zellen vorlagen. Danach wurden die Zellkulturflaschen horizontal geschwenkt, um die Zellen gleichmäßig zu verteilen, und die vorliegende Zelldichte kontrolliert. Die anschließende Inkubation erfolgte bei $37{ }^{\circ} \mathrm{C}$ im Inkubator.

Da die Verdopplungszeit von Jurkat-Zellen 25-35 Stunden und von SU-DHL-4-Zellen etwa 40 Stunden beträgt, wurden die jeweiligen Zellkulturen alle zwei bis drei Tage passagiert. Dazu wurde die Zellkultur unter der Sterilbank aus der Zellkulturflasche in ein 50-ml-Reaktionsgefäß überführt und für fünf Minuten bei $350 \mathrm{~g}$ zentrifugiert. Anschließend wurde der Überstand unter der Sterilbank abgesaugt. Nach Resuspension der Zellen mit $1 \mathrm{ml}$ RPMI-Medium II wurde die Anzahl der Zellen bestimmt und die Zellen erneut in 25 - $\mathrm{cm}^{2}$ - oder 75 - $\mathrm{cm}^{2}$-Zellkulturflaschen ausgesät, so dass ca. $1 \mathrm{ml}$ RMPI-Medium II pro $0,5 \times 10^{6}$ Zellen eingesetzt wurde. Die Anzahl der benötigten Zellkulturflaschen ergab sich dabei jeweils aus der Ursprungsmenge an Zellen. Abschließend wurden die Zellkulturflaschen horizontal geschwenkt, um die Zellen gleichmäßig zu verteilen, und die Zelldichte nochmals kontrolliert. Die nachfolgende Inkubation erfolgte ebenfalls bei 37 ${ }^{\circ} \mathrm{C}$ im Inkubator. Nach einer Inkubationszeit von zwei bis drei Tagen konnte die nächste Passage der Zellen vorgenommen werden.

Um die Anzahl an Passagen gering zu halten, wurden die jeweils überschüssigen Jurkat-Zellen bei der 3., 6. und 9. Passage und die SU-DHL-4-Zellen bei der 3. und 4. 
Passage kryokonserviert. Dafür wurde zunächst die Anzahl der Jurkat- oder SU-DHL4-Zellen in den Zellkulturflaschen bestimmt. Danach wurden die jeweiligen Zellen unter der Sterilbank in ein 50-ml-Reaktionsgefäß überführt und fünf Minuten bei $250 \mathrm{~g}$ zentrifugiert. Der Überstand wurde unter der Sterilbank abgesaugt und das Zellpellett in $1 \mathrm{ml}$ RPMI-Medium III resuspendiert. Das zellhaltige RPMI-Medium III wurde so aufgeteilt, dass in jedem Reaktionsgefäß $5 \times 10^{6}$ Zellen enthalten waren. Jedes Reaktionsgefäß wurde anschließend mit RPMI-Medium III auf 700 pl aufgefüllt. Zusätzlich erfolgte die Zugabe von $200 \mu \mathrm{l}$ FBS. Anschließend wurde zu jedem Reaktionsgefäß tröpfchenweise $100 \mu l$ DMSO zugegeben und alles vorsichtig vermischt. Die Reaktionsgefäße wurden zügig in den Einfrierbehälter überführt und bei $-85{ }^{\circ} \mathrm{C}$ gelagert. Das im Einfrierbehälter enthaltene 2-Propanol bewirkt ein schonendes und langsames Einfrieren der Zellen von etwa $1{ }^{\circ} \mathrm{C}$ Temperaturreduktion pro Minute.

Für die Durchführung der in den Abschnitten 2.7, 2.8 und 2.10 beschriebenen Versuche wurde jeweils ein Reaktionsgefäß aufgetaut. Dabei erfolgte der Auftauvorgang analog zu dem bereits oben beschriebenen Auftau- und Kultivierungsvorgang der gekauften Zelllinien. Es wurden ausschließlich Zellen bis zur 20. Passage verwendet. Die jeweiligen Zellkulturen wurden über einen Zeitraum von mindestens einer Woche passagiert, bevor diese für die genannten Versuche eingesetzt wurden.

\subsubsection{Gewinnung mononukleärer Zellen aus Buffy Coats}

Um die Auswirkungen von Transfektionsreagenz und microRNA-Inhibitor 19b auf humane Primärzellen zu untersuchen, wurden mononukleäre Zellen aus Buffy Coats verwendet. Buffy Coats können durch die Auftrennung einer Vollblutspende gewonnen werden und enthalten eine Mischung verschiedener Zellarten. Für die nachfolgenden Versuche mussten die benötigten mononukleäre Zellen (MNZ) aus den Buffy Coats isoliert werden.

Für die Isolierung der Leukozytenschicht wurden die Buffy Coats durchmischt und anschließend $25 \mathrm{ml}$ in ein 50-ml-Reaktionsgefäß überführt. Des Weiteren wurde die Natriumcitrat-Lösung im Verhältnis 1:1 mit PBS gemischt. Das erhaltene Gemisch wird 
als Natriumcitrat-PBS-Lösung bezeichnet. 25 ml Natriumcitrat-PBS-Lösung wurden anschließend zu den Zellen aus den Buffy Coats in das 50-ml-Reaktionsgefäß gegeben und die erhaltene Lösung nachfolgend als Zellsuspension bezeichnet. Daraufhin wurden in einem weiteren 50-ml-Reaktionsgefäß $20 \mathrm{ml}$ Trenn-Lösung vorgelegt und vorsichtig mit $30 \mathrm{ml}$ Zellsuspension überschichtet. Nach einer Zentrifugation mit $800 \mathrm{~g}$ für $30 \mathrm{Minu}-$ ten mit Bremse $\mathrm{R}=0$ wurde die oben stehende Plasmaschicht teilweise abgesaugt und 3-6 ml der darunter liegenden Leukozytenschicht in ein weiteres 50-ml-Reaktionsgefäß überführt. Daraufhin wurden die erhaltenen MNZ mit dem dreifachen Volumen der hergestellten Natriumcitrat-PBS-Lösung gemischt und mit $100 g$ für zehn Minuten zentrifugiert. Der erhaltene Überstand wurde nach dem Zentrifugieren abgesaugt. Das verbliebene Zellpellett wurde mit $8 \mathrm{ml}$ Natriumcitrat-PBS-Lösung resuspendiert und erneut mit $100 g$ für zehn Minuten zentrifugiert. Nach dem Absaugen des Überstandes wurde das wiederum erhaltene Zellpellett unter der Sterilbank in 5 ml RPMI-Medium III resuspendiert. Es erfolgte eine Zellzählung in einer Verdünnung von 1:20 in Natriumcitrat-Lösung.

\subsection{45-Annexin V-Färbung von Jurkat-Zellen und humanen mononukleären Zellen}

Die Farbstoffmarkierung zur Bestimmung der Apoptoserate der untersuchten Zellen wurde mit einer CD45-Annexin V-Färbung durchgeführt. Hierbei handelte es sich um eine zweistufige Färbung, wobei zunächst die CD45-Oberflächenantigene von Leukozyten angefärbt wurden. Anschließend erfolgte eine zweite Färbung mit einem Annexin VAntikörper. Dieser bindet selektiv an negative Phospholipide (bspw. Phosphatidylserin), welche in vitalen Zellen in der inneren Schicht der Zellmembran zu finden sind. Im Rahmen der Apoptose geht die Asymmetrie der Zellmembran verloren. Phosphatidylserin ist dann auch verstärkt in der äußeren Schicht der Zellmembran zu finden und kann daher mit Fluorochrom-markierten Annexin V-Antikörpern sichtbar gemacht werden. Dementsprechend können nach der Zellfärbung zunächst die Leukozyten in der Probe 
identifiziert und zudem zwischen apoptotischen und vitalen Leukozyten unterschieden werden.

Für die Färbung wurden die Proben der Jurkat-Zellen oder mononukleären Zellen aus den 6- oder 12-Loch-Zellkulturplatten in je ein FACS-Röhrchen überführt. Die anschließende Zentrifugation der Jurkat-Zellen erfolgte mit $350 \mathrm{~g}$ für fünf Minuten, der mononukleären Zellen mit $400 g$ für acht Minuten. Der Überstand wurde verworfen, die Zellpellets in je 2 ml MACS-Puffer resuspendiert und wiederum bei den zuvor genannten Bedingungen zentrifugiert. Nach dem erneuten Verwerfen des Überstandes wurde jedes Zellpellet in 100 pl MACS-Puffer resuspendiert. Anschließend erfolgte die Zugabe von je 0,5 pl CD45 APC-Antikörper. Nach zehnminütiger Inkubation unter Lichtausschluss wurden die Proben mit je 2 ml MACS-Puffer aufgefüllt und erneut bei den oben genannten Bedingungen zentrifugiert. Anschließend wurde jedes Zellpellet in 100 pl Annexin V-Puffer resuspendiert und 2,5 $\mathrm{ll}$ des Annexin V PacificBlue-Antikörpers dazugegeben. Nach zehnminütiger Inkubation unter Lichtausschluss wurde je $200 \mu$ l Annexin V-Puffer hinzugefügt. Die hergestellten Proben konnten abschließend im Durchflusszytometer untersucht werden. Hier wurde der Anteil der CD45-positiven Zellen und als Apoptoserate der Anteil der zusätzlich auch Annexin V-positiven Zellen bestimmt.

\subsection{Resuspension und Aliquottierung des microRNA-Inhibitors und der microRNA-Kontrolle}

Um den in dieser Arbeit eingesetzten microRNA-Inhibitor 19b und die microRNA-Kontrolle für die Transfektions- und Apoptosemessungen nutzen zu können, wurden diese nach Anweisung des Herstellers resuspendiert und anschließend aliquotiert. Hierzu wurden die gelieferten Reaktionsgefäße mit den jeweiligen Substanzen mit Hilfe der Tischzentrifuge kurz zentrifugiert und nach Absprühen mit Ethanol und RNase in die bereits mit RNase gereinigte Sterilbank gelegt. Hier erfolgte die Zugabe von je 200 ll Puffer-Lösung zu den gelieferten Reaktionsgefäßen. Die entstandene Lösung wurde einige Minuten ste- 
hen gelassen, dann gründlich gemischt und erneut stehen gelassen. Nach wiederholter Durchmischung erfolgte die Aliquotierung in mehrere Eppendorfgefäße, wobei $2 \mu l$ aus einem Aliquot 50 pmol microRNA-Inhibitor 19b oder microRNA-Kontrolle enthielten. Die Eppendorfgefäße wurden bis zu den Versuchen bei $-20{ }^{\circ} \mathrm{C}$ gelagert.

\subsection{Analyse der Transfektionsbedingungen bei Jurkat-Zellen}

Bevor die Wirkung des microRNA-Inhbitors-19b auf die Apoptoserate der Jurkat-Zellen untersucht werden konnte, mussten zunächst die optimalen Transfektionsbedingungen für die Jurkat-Zellen ermittelt werden. Dazu war zu berücksichtigen, dass unterschiedliche Transfektionsreagenzien oftmals zu unterschiedlichen Transfektionsraten führen. Als Transfektionsreagenzien wurden HiPerfect, Lipofectamine und siLentFect getestet, bei denen es sich um Reagenzien zur liposomalen Transfektion handelt. Die Verwendung der unterschiedlichen Transfektionsreagenzien orientierte sich an den jeweiligen Herstellerempfehlungen. Als zu transfizierende Testsubstanz wurde jeweils die microRNAKontrolle eingesetzt.

Für die Testung der Transfektionsreagenzien wurden die Jurkat-Zellen gezählt und unter der Sterilbank in ein 50-ml-Reaktionsgefäß gegeben, gefolgt von einer fünfminütigen Zentrifugation bei 350 g. Nach Verwerfen des Überstands wurde das erhaltene Zellpellett in $1 \mathrm{ml}$ MEM-Medium pro 1.000.000 Zellen unter der mit RNase gereinigten Sterilbank resuspendiert.

Für die Bestimmung der Transfektionsrate mit HiPerfect als Transfektionsreagenz wurden 500.000 Zellen in $800 \mu \mathrm{l}$ MEM-Medium in drei Probenkammern einer 12-LochZellkulturplatte gegeben. Anschließend wurden für die Proben je 50 pmol (2 $\mu l)$ der microRNA-Kontrolle in je 200 ll MEM-Medium in einem Eppendorfgefäß verdünnt. Zu dieser Lösung wurden pro Probe $6 \mu$ l HiPerfect als Transfektionsreagenz gegeben. Nach fünfminütiger Inkubation bei Raumtemperatur wurden $200 \mu \mathrm{l}$ der hergestellten Lösung zu den Proben hinzugegeben und die 12-Loch-Zellkulturplatte bei $37^{\circ} \mathrm{C}$ in den Inku- 
bator gestellt. Sechs Stunden nach Transfektion erfolgte die Zugabe von 600 pl RPMIMedium II pro Probenkammer und nach ein, zwei und drei Tagen die Auswertung der Transfektionsrate von je einer Probenkammer per Durchflusszytometrie. Hierzu wurden die Zellen aus der jeweiligen Probe in ein FACS-Röhrchen überführt und mit $350 \mathrm{~g}$ für fünf Minuten zentrifugiert. Der Überstand wurde absaugt, die Zellpelletts mit je $300 \mu l$ MACS-Puffer resuspendiert und die Transfektionsrate durchflusszytometrisch analysiert. Für die Ermittlung der Transfektionsrate wurden dabei die Zellen markiert, die eine stark fluoreszierende abgrenzbare Population bildeten und bei den unbehandelten Zellen nicht sichtbar waren (Abb. 2.1).
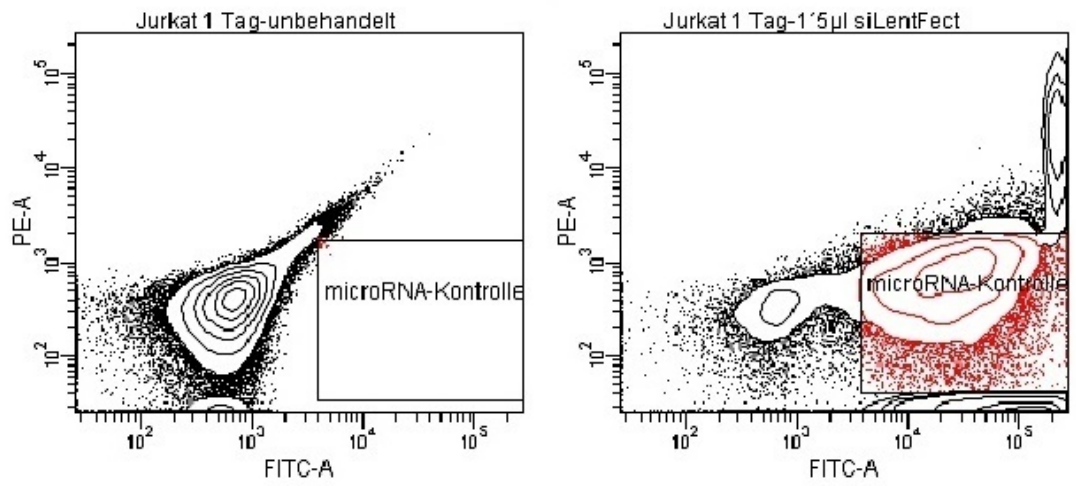

Abbildung 2.1: Bestimmung der Transfektionsrate mit Hilfe der Durchflusszytometrie für die fluoreszenzmarkierten und damit transfizierten Zellen (FITC-positiv, rote Population in rechter Abbildung) im Vergleich zu unbehandelten Zellen (linke Abbildung)

Für die Bestimmung der Transfektionsrate mit Lipofectamine als Transfektionsreagenz wurden 500.000 Zellen in 900 pl MEM-Medium in drei Probenkammern einer 12Loch-Zellkulturplatte vorgelegt. Für die Proben wurden in einem Eppendorfgefäß je 50 pmol $(2 \mu l)$ der microRNA-Kontrolle in je $50 \mu l$ MEM-Medium verdünnt. Zusätzlich wurden je $6 \mu l$ Lipofectamine und je 50 ll MEM-Medium in einem weiteren Eppendorfgefäß vorgelegt. Anschließend wurden die Substanzen aus beiden Eppendorfgefäßen gründlich miteinander vermischt und fünf Minuten bei Raumtemperatur inkubiert, sodass eine microRNA-Kontrolle-Lipofectamine-Lösung entstand. Daraufhin wurden je 100 pl dieser Lösung tröpfchenweise zu den Proben in der 12-Loch-Zellkulturplatte gegeben und ein, zwei und drei Tage bei $37^{\circ} \mathrm{C}$ inkubiert. Die Bestimmung der Transfektionsrate für 
die Proben mit Lipofectamine als Transfektionsreagenz erfolgte analog zu dem oben beschriebenen Verfahren bei HiPerfect.

Die Transfektion mit siLentFect erfolgte analog zu der Transfektion mit Lipofectamine, wobei anstatt $6 \mu$ l Lipofectamine 1,5 $\mu \mathrm{l}$ siLentFect eingesetzt wurden. Zudem wurde gemäß den Herstellerangaben die Inkubationszeit für die microRNA-KontrollesiLentFect-Lösung von fünf Minuten auf 20 Minuten erhöht.

Für alle untersuchten Proben wurde jeweils eine Kontrollprobe untersucht, die ausschließlich Jurkat-Zellen im jeweiligen Nährmedium enthielt. Die Volumina der Nährmedien wurden so angepasst, dass die Zellkonzentrationen in den transfizierten Proben mit der Kontrollprobe äquivalent waren. Diese Probe diente bei der Durchflusszytometrie als untransfizierte und damit ungefärbte Kontrolle.

Nach Identifikation von siLentFect als Transfektionsreagenz mit der höchsten Transfektionsrate bei Jurkat-Zellen erfolgte die Optimierung der Transfektionsbedingungen unter Verwendung von siLentFect, um die Transfektionsrate weiter zu erhöhen. Die Probenvorbereitung, Inkubation und Messung der Transfektionsrate erfolgte nach der oben aufgeführten Beschreibung. Es wurde eine Erhöhung der Konzentration an siLentFect von 1,5 $\mu \mathrm{l}$ auf 2,5 $\mathrm{pl}$ und $4 \mathrm{\mu l}$ getestet. Zudem wurde eine Erhöhung der Konzentration an microRNA-Kontrolle von 50 pmol auf 75 pmol und 100 pmol pro Probe untersucht. Die Inkubationszeit lag bei zwei Tagen und die Transfektionsrate wurde wiederum mit dem Durchflusszytometer bestimmt.

\subsection{Analyse der Transfektionsbedingungen bei SU-DHL-4-Zel- len}

Neben der Transfektion von Jurkat-Zellen sollte in dieser Arbeit auch die Transfektion von SU-DHL-4-Zellen mit dem microRNA-Inhibitor untersucht werden. Dazu wurden Lipofectamine und siLentFect als Transfektionsreagenzien eingesetzt. Auf den Test von HiPerfect wurde aufgrund der geringen Transfektionsrate bei der Transfektion von 
Jurkat-Zellen verzichtet.

Die Transfektion der SU-DHL-4-Zellen mit siLentFect erfolgte gemäß der Beschreibung für Jurkat-Zellen. Insgesamt wurden Proben mit 1,5 $\mu l, 2,5 \mu$ l oder $4 \mu l$ siLentFect transfiziert. Die Inkubationszeit für die microRNA-Kontrolle-siLentFect-Lösung betrug wie bei den Jurkat-Zellen 20 Minuten. Die Proben wurden zwei oder drei Tage bei $37^{\circ} \mathrm{C}$ inkubiert. Abschließend erfolgte die Auswertung der Transfektionsrate per Durchflusszytometrie.

Da die Transfektion mit siLentFect unter diesen Bedingungen nicht erfolgreich war, wurde ein Mediumwechsel getestet. Hierzu erfolgte das Aussäen der Zellen gemäß der vorstehenden Beschreibung für das Transfektionsreagenz siLentFect in MEM-Medium. Am Folgetag der Transfektion wurde der Inhalt von jeder Probe unter der Sterilbank in je ein 50-ml-Reaktionsgefäß überführt und fünf Minuten mit $350 g$ zentrifugiert. Der Überstand wurde unter der Sterilbank abgesaugt und jedes Zellpellet in $1 \mathrm{ml}$ RPMI-Medium II resuspendiert. Nach Überführung der Zelllösung in die ursprünglichen Probenkammern der 12-Loch-Zellkulturplatte erfolgte die weitere Inkubation für insgesamt zwei oder drei Tage mit anschließender Bestimmung der Transfektionsrate mittels Durchflusszytometrie.

Weiterhin wurde unter der Sterilbank pro Probe 500.000 SU-DHL-4-Zellen in 800 pl RPMI-Medium III ausgesät. Die Transfektion erfolgte gemäß der obigen Beschreibung. Am Folgetag wurde zu jeder Probe 100 pl FBS gegeben und die beschriebene Inkubation dann fortgesetzt, gefolgt von der Auswertung der Transfektionsrate per Durchflusszytometrie nach zwei oder drei Tagen Inkubation.

Zudem wurde die Transfektion von SU-DHL-4-Zellen mit Lipofectamine gemäß dem in Abschnitt 2.7 beschriebenen Transfektionsverfahren getestet. Es wurden je 500.000 SU-DHL-4-Zellen in je 800 pl RPMI-Medium III in einer 12-Loch-Zellkulturplatte vorgelegt. Bei diesen Proben wurden ebenfalls 50 pmol (2 ul) der microRNA-Kontrolle und 6 pl Lipofectamine eingesetzt. Die hergestellten Proben wurden zwei oder drei Tage bei $37^{\circ} \mathrm{C}$ inkubiert, wobei am Tag nach der Transfektion zu jeder Probe $100 \mu$ l FBS gegeben 
wurden. Danach erfolgte die durchflusszytometrische Auswertung der Transfektionsrate.

Für alle untersuchten Proben wurde jeweils eine Kontrollprobe untersucht, die ausschließlich SU-DHL-4-Zellen im jeweiligen Nährmedium enthielt. Die Volumina der Nährmedien wurden so angepasst, dass die Zellkonzentrationen in den transfizierten Proben mit der Kontrollprobe äquivalent war.

\subsection{Analyse der Transfektionsbedingungen bei humanen mono- nukleären Zellen}

Neben der Transfektion von Jurkat-Zellen und SU-DHL-4-Zellen mit einem micro-RNAInhibitor sollte in dieser Arbeit auch die Transfektion von humanen mononukleären Zellen aus Buffy Coats mit dem micro-RNA-Inhibitor 19b untersucht werden. Als Transfektionsreagenzien wurden dazu Lipofectamine und siLentFect eingesetzt. Als zu transfizierende microRNA wurde die microRNA-Kontrolle verwendet.

Für die Versuchsdurchführung wurden die humanen MNZ mittels Dichtegradientenzentrifugation isoliert und die Zellzahl bestimmt. Anschließend wurde so viel RPMIMedium III dazugegeben, dass die Zellen in einer Konzentration von 1.000.000 Zellen pro $0,5 \mathrm{ml}$ im 50-ml-Reaktionsgefäß vorlagen.

Die Transfektion der humanen MNZ mit Lipofectamine erfolgte gemäß dem in Abschnitt 2.7 beschriebenen Transfektionsverfahren. Im Unterschied zu der dort für 500.000 Jurkat-Zellen beschriebenen Transfektion mit Lipofectamine wurden 1.000.000 MNZ in 900 l MEM-Medium in die benötigte Anzahl Probenkammern einer 12-Loch-Zellkulturplatte überführt. Es wurden auch hier $6 \mu \mathrm{l}$ Lipofectamine und 50 pmol (2 $\mu l)$ microRNAKontrolle verwendet. Die Inkubation nach Transfektion erfolgte für zwei und drei Tage bei $37^{\circ} \mathrm{C}$ im Inkubator. Die Bestimmung der Transfektionsrate erfolgte per Durchflusszytometrie.

Auch die Transfektion mit siLentFect erfolgte gemäß der Beschreibung aus Abschnitt 2.7, wobei 1.000.000 humane MNZ in $900 \mu$ l MEM-Medium in die benötigte An- 
zahl Probenkammern einer 12-Loch-Zellkulturplatte vorgelegt wurden. Die Transfektion erfolgte jeweils mit 1,5 $\mu$ l oder $4 \mu \mathrm{l}$ siLentFect und 50 pmol (2 $\mu \mathrm{l})$ microRNA-Kontrolle. Nach der Transfektion wurden die Proben für zwei oder drei Tage bei $37^{\circ} \mathrm{C}$ inkubiert, gefolgt von der Auswertung der Transfektionsrate per Durchflusszytometrie.

Da die Transfektion unter den oben aufgeführten Bedingungen mit Aussäen der humanen MNZ in MEM-Medium nicht erfolgreich war, wurde die Kultivierung in RPMIMedium III getestet. Hierzu wurden unter der mit RNase gereinigten Sterilbank 1.000.000 Zellen in $800 \mu \mathrm{l}$ RPMI-Medium III in eine 12-Loch-Zellkulturplatte ausgesät. Die Transfektion erfolgte sowohl für Lipofectamine als auch siLentFect wie oben beschrieben, gefolgt von der Inkubation. Am Folgetag der Transfektion wurde unter der Sterilbank zu jeder Probe 100 pl FBS hinzugegeben und dann die Inkubation fortgesetzt sowie anschließend die Transfektionsrate per Durchflusszytometrie bestimmt.

Für alle untersuchten Proben wurde jeweils eine Kontrollprobe untersucht, die ausschließlich die jeweilige Zellzahl im entsprechenden Nährmedium enthielt. Das Volumen des Nährmediums wurde so angepasst, dass die Zellkonzentration in der transfizierten Probe und der Kontrollprobe äquivalent war.

\subsection{Transfektions- und Apoptoserate von Jurkat-Zellen bei Trans- fektion mit dem microRNA-Inhibitor $19 b$}

Nach der Optimierung der Transfektionsbedingungen von Jurkat-Zellen wurde die Transfektions- und Apoptoserate bei der Transfektion mit dem microRNA-Inhibitor 19b untersucht. Um eine Aussage über die Auswirkung des microRNA-Inhibitors auf die JurkatZellen machen zu können, war es nötig, auch den Einfluss der Zellkultur und des Transfektionsreagenzes auf die Apoptoserate zu untersuchen. Zusätzlich erfolgte zudem eine Transfektion der Jurkat-Zellen mit einer microRNA-Kontrolle, welche nicht komplementär zu bekannten humanen microRNA-Sequenzen war (Tab. 2.8).

Für die Kontrollansätze wurden ausschließlich je 500.000 Jurkat-Zellen in $1000 \mu l$ 
Tabelle 2.8: Ansätze zur Untersuchung der Transfektions- und Apoptoseraten von JurkatZellen bei Transfektion mit dem microRNA-Inhibitor $19 \mathrm{~b}$

\begin{tabular}{cccccc}
\hline Zellzahl & $\begin{array}{c}\text { MEM- } \\
\text { Medium }\end{array}$ & $\begin{array}{c}\text { siLent- } \\
\text { Fect }\end{array}$ & $\begin{array}{c}\text { microRNA- } \\
\text { Kontrolle }\end{array}$ & $\begin{array}{c}\text { microRNA- } \\
\text { Inhibitor 19b }\end{array}$ & $\begin{array}{c}\text { Annexin V- } \\
\text { färbung }\end{array}$ \\
\hline \hline 500.000 & $1000 \mathrm{\mu l}$ & - & - & - & - \\
\hline 500.000 & $1000 \mu \mathrm{l}$ & - & - & - & + \\
\hline 500.000 & $1000 \mu \mathrm{l}$ & $2,5 \mu \mathrm{l}$ & - & - & + \\
\hline 500.000 & $1000 \mu \mathrm{l}$ & $2,5 \mu \mathrm{l}$ & $50 \mathrm{pmol}$ & - & + \\
\hline 500.000 & $1000 \mu \mathrm{l}$ & $2,5 \mu \mathrm{l}$ & - & $50 \mathrm{pmol}$ & + \\
\hline
\end{tabular}

MEM-Medium ausgesät und inkubiert. Sie werden im Folgenden als unbehandelte Proben bezeichnet. Bei den weiteren Ansätzen wurden je 500.000 Jurkat-Zellen in 900 pl MEM-Medium in einer 12-Loch-Zellkulturplatte vorgelegt. Für die nur mit siLentFect behandelte Probe wurden 2,5 $\mu$ l siLentFect und $100 \mu$ l MEM-Medium in ein Eppendorfgefäß vorgelegt und gründlich gemischt. Nach 20-minütiger Inkubation bei Raumtemperatur wurden $100 \mu \mathrm{l}$ der Lösung tropfenweise zu den Zellen der Probe gegeben. Für die Proben mit microRNA-Kontrolle und microRNA-Inhibitor 19b wurden je 2,5 $\mu$ l siLentFect und $50 \mu l$ MEM-Medium in ein Eppendorfgefäß vorgelegt. Die dadurch entstehende Lösung wird im Folgenden als siLentFect-Lösung bezeichnet. Zusätzlich wurde je Probe 50 pmol (2 pl) microRNA-Kontrolle bzw. 50 pmol (2 pl) microRNA-Inhibitor 19b in je 50 pl MEM-Medium in zwei weitere Eppendorfgefäße gegeben. Anschließend wurde die Hälfte der siLentFect-Lösung zum Eppendorfgefäß mit der microRNA-Kontrolle und die andere Hälfte der siLentFect-Lösung zum Eppendorfgefäß mit dem microRNA-Inhibitor 19b gegeben, 20 Minuten bei Raumtemperatur inkubiert und $100 \mathrm{ml}$ tropfenweise zu den Zellen der jeweiligen Probe zugegeben. Alle Proben wurden bei $37^{\circ} \mathrm{C}$ in den Inkubator gestellt.

Am Folgetag wurde bei allen Proben ein Mediumwechsel vorgenommen, um die Wachstumsbedingungen der Jurkat-Zellen zu verbessern. Hierzu wurde die zellhaltige Lösung jeder Probe unter der Sterilbank in je ein 50-ml-Reaktionsgefäß überführt und fünf Minuten mit $350 \mathrm{~g}$ zentrifugiert. Nach Absaugen des Überstands wurde das jeweilige Zellpellet in $1 \mathrm{ml}$ RPMI-Medium II resuspendiert und die Probe zurück in die 
12-Loch-Zellkulturplatte überführt. Anschließend wurde die Inkubation bei $37{ }^{\circ} \mathrm{C}$ fortgesetzt. Die gesamte Inkubationszeit betrug zwei oder drei Tage. Die Bewertung der Apoptose- und Transfektionsrate erfolgte, wie in Abschnitt 2.5 beschrieben, mit Hilfe der CD45-Annexin V-Färbung und anschließender Durchflusszytometrie. Die Auswertung dieser dreifarbigen Durchflusszytometrie wurde beispielhaft in Abbildung 2.2 dargestellt. Zum einen wurde von den CD45-positiven Zellen (Farbstoff APC) die Annexin V-positive Population der apoptotischen Zellen (Farbstoff Pacific Blue) abgegrenzt. Zum anderen erfolgte eine Abgrenzung von Zellen, die den Fluoreszenzfarbstoff FITC der microRNA(-Kontrolle oder -Inhibitor 19b) aufgenommen hatten, gegenüber nicht gefärbten Zellen. Der jeweils ermittelte Anteil an Annexin V-Pacific Blue-positiven bzw. FITC-positiven Zellen bildete die Apoptose- bzw. Transfektionsrate.
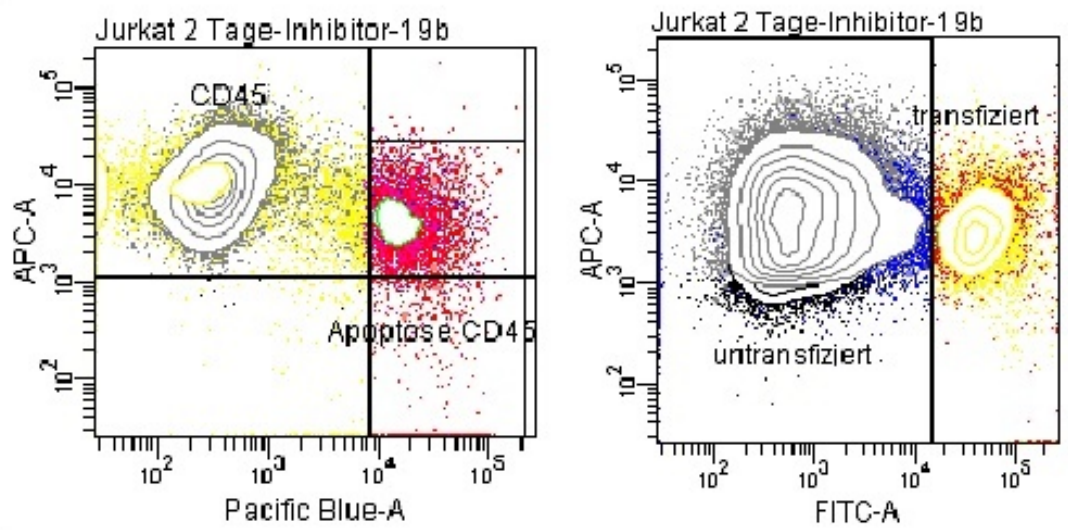

Abbildung 2.2: Bestimmung von Transfektions- und Apoptoseraten von Jurkat-Zellen mit Hilfe der Durchflusszytometrie: Apoptoserate als Annexin V-Pacific Blue-positive Population (rot) von CD45 APC-positiven Zellen im linken Teil der Abbildung bestimmt. Transfektionsrate als Anteil der FITC-positiven Zellen (gelb) im rechten Teil der Abbildung dargestellt 


\subsection{Transfektions- und Apoptoserate von humanen mononukle- ären Zellen bei Transfektion mit dem microRNA-Inhibitor $19 \mathrm{~b}$}

Die Transfektions- und Apoptoseraten für die Transfektion von humanen MNZ mit dem microRNA-Inhibitor 19b wurden analog zu den Messungen aus Abschnitt 2.10 untersucht. Zusätzlich zum microRNA-Inhibitor 19b erfolgte auch hier eine Transfektion mit der microRNA-Kontrolle sowie der Ansatz weiterer Kontrollen (Tab. 2.9).

Tabelle 2.9: Proben für die Untersuchung der Transfektions- und Apoptoserate von humanen MNZ bei Transfektion mit dem microRNA-Inhibitor 19b

\begin{tabular}{|c|c|c|c|c|c|c|}
\hline Zellzahl & $\begin{array}{l}\text { RPMI- } \\
\text { Medium } \\
\text { III }\end{array}$ & siLentFect & $\begin{array}{c}\text { microRNA- } \\
\text { Kontrolle in } \\
50 \mu \text { l MEM- } \\
\text { Medium }\end{array}$ & $\begin{array}{c}\text { microRNA- } \\
\text { Inhibitor } 19 \mathrm{~b} \\
\text { in } 50 \mu \mathrm{l} \\
\text { MEM- } \\
\text { Medium }\end{array}$ & FBS & $\begin{array}{l}\text { Annexin V } \\
\text { färbung }\end{array}$ \\
\hline 1.000 .000 & $900 \mu \mathrm{l}$ & - & - & - & $100 \mu \mathrm{l}$ & - \\
\hline 1.000 .000 & $900 \mu \mathrm{l}$ & - & - & - & $100 \mu \mathrm{l}$ & + \\
\hline 1.000 .000 & $800 \mu \mathrm{l}$ & $\begin{array}{c}4 \mu \mathrm{l} \text { in } 100 \mu \mathrm{l} \\
\text { MEM- } \\
\text { Medium }\end{array}$ & - & - & $100 \mu \mathrm{l}$ & + \\
\hline 1.000 .000 & $800 \mu \mathrm{l}$ & $\begin{array}{c}4 \mu \mathrm{l} \text { in } 50 \mu \mathrm{l} \\
\text { MEM- } \\
\text { Medium }\end{array}$ & $\begin{array}{c}50 \text { pmol } \\
(2 \mu l)\end{array}$ & - & $100 \mu \mathrm{l}$ & + \\
\hline 1.000 .000 & $800 \mu \mathrm{l}$ & $\begin{array}{c}4 \mu \mathrm{l} \text { in } 50 \mu \mathrm{l} \\
\text { MEM- } \\
\text { Medium }\end{array}$ & - & $\begin{array}{c}50 \text { pmol } \\
(2 \mu \mathrm{l})\end{array}$ & $100 \mu \mathrm{l}$ & + \\
\hline
\end{tabular}

Für die Kontrollansätze wurden je 1.000.000 humane Leukozyten in 900 pl RPMIMedium III ausgesät und inkubiert. Sie werden im Folgenden als unbehandelte Proben bezeichnet. Bei den weiteren Proben wurden je 1.000.000 humane Leukozyten in 800 pl RPMI-Medium III in einer 12-Loch-Zellkulturplatte vorgelegt. Für die nur mit siLentFect behandelte Probe wurden 4 pl siLentFect und $100 \mu$ l MEM-Medium in einem Eppendorfgefäß gründlich gemischt. Nach 20 minütiger Inkubation bei Raumtemperatur wurden 100 pl der Lösung tropfenweise zu den Zellen gegeben. Für die Proben mit microRNA- 
Kontrolle und microRNA-Inhibitor 19b wurden je 4 pl siLentFect und 50 pl MEMMedium in ein Eppendorfgefäß vorgelegt (siLentFect-Lösung). Zusätzlich wurden in ein

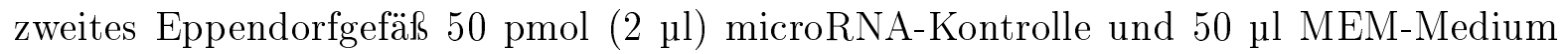
sowie in ein drittes Eppendorfgefäß 50 pmol (2 pl) microRNA-Inhibitor 19b und $50 \mu l$ MEM-Medium gegeben. Anschließend wurde jeweils die Hälfte der siLentFect-Lösung zum Eppendorfgefäß mit microRNA-Kontrolle und dem mit microRNA-Inhibitor 19b gegeben, diese 20 Minuten bei Raumtemperatur inkubiert und je 100 pl tropfenweise den Zellen der jeweiligen Proben zugegeben. Alle Proben wurden bei $37{ }^{\circ} \mathrm{C}$ in den Inkubator gestellt. Drei Stunden nach Transfektion wurde unter der Sterilbank 100 pl FBS zu jeder Probe hinzugefügt und die Proben anschließend bei $37^{\circ} \mathrm{C}$ weiter inkubiert. Die gesamte Inkubationszeit nach Transfektion betrug zwei oder drei Tage. Anschließend erfolgte die CD45-Annexin V-Färbung und die Untersuchung der Proben mittels Durchflusszytometrie.

Da sich herausstellte, dass bei diesen Transfektionsbedingungen nur eine unzureichende Anzahl an Zellen für die Färbung und die durchflusszytometrische Messung in den Proben vorhanden war, wurden zusätzlich Ansätze mit höherer Zellzahl untersucht (Tab. 2.10)

Auch für die Proben mit erhöhter Zellzahl erfolgte die Probenvorbereitung gemäß der vorstehenden Beschreibung, wobei die eingesetzte Zellzahl auf 6.000.000 erhöht wurde. Zudem wurden die Mengen der eingesetzten Nährmedien, Transfektionsmedien und microRNAs verdoppelt und die Versuche in 6-Loch-Zellkulturplatten durchgeführt. Zur Bewertung von Apoptose- und Transfektionsrate wurden die Zellen nach zweitägiger Inkubation aus den Zellkulturplatten in je ein FACS-Röhrchen überführt und anschließend die am Boden der Probenkammern festgesetzten Zellen mit Hilfe eines Zellschabers gelöst. Mit je $1 \mathrm{ml}$ MEM-Medium wurden die gelösten Zellen in den jeweiligen Probenkammern der 6-Loch-Zellkulturplatte aufgenommen und in das zugehörige FACS-Röhrchen überführt. Die durchflusszytometrische Untersuchung der Apoptose- und Transfektionsraten wurde wie zuvor beschrieben durchgeführt. 
Tabelle 2.10: Untersuchung der Transfektions- und Apoptoserate von humanen MNZ bei Transfektion mit dem microRNA-Inhibitor 19b, Ansätze mit erhöhter Zellzahl

\begin{tabular}{|c|c|c|c|c|c|c|}
\hline Zellzahl & $\begin{array}{l}\text { RPMI- } \\
\text { Medium } \\
\quad \text { III }\end{array}$ & siLent-Fect & $\begin{array}{c}\text { microRNA- } \\
\text { Kontrolle in } \\
100 \mu l \text { MEM- } \\
\text { Medium }\end{array}$ & $\begin{array}{c}\text { microRNA- } \\
\text { Inhibitor } 19 \mathrm{~b} \\
\text { in } 100 \mu \mathrm{l} \\
\text { MEM- } \\
\text { Medium }\end{array}$ & FBS & $\begin{array}{l}\text { Apoptose- } \\
\text { färbung }\end{array}$ \\
\hline 6.000 .000 & $1800 \mu \mathrm{l}$ & - & - & - & $200 \mu \mathrm{l}$ & - \\
\hline 6.000 .000 & $1800 \mu \mathrm{l}$ & - & - & - & $200 \mu \mathrm{l}$ & gefärbt \\
\hline 6.000 .000 & $1600 \mu \mathrm{l}$ & $\begin{array}{c}8 \mu \mathrm{l} \text { in } 200 \mu \mathrm{l} \\
\text { MEM- } \\
\text { Medium }\end{array}$ & - & - & $200 \mu \mathrm{l}$ & gefärbt \\
\hline 6.000 .000 & $1600 \mu \mathrm{l}$ & $\begin{array}{c}8 \mu \mathrm{l} \text { in } 100 \mu \mathrm{l} \\
\text { MEM- } \\
\text { Medium }\end{array}$ & $100 \mathrm{pmol}$ & - & $200 \mu \mathrm{l}$ & gefärbt \\
\hline 6.000 .000 & $1600 \mu \mathrm{l}$ & $\begin{array}{c}8 \mu \mathrm{l} \text { in } 100 \mu \mathrm{l} \\
\text { MEM- } \\
\text { Medium }\end{array}$ & - & $100 \mathrm{pmol}$ & $200 \mu \mathrm{l}$ & gefärbt \\
\hline 6.000 .000 & $1600 \mu \mathrm{l}$ & $\begin{array}{c}8 \mu \mathrm{l} \text { in } 100 \mu \mathrm{l} \\
\text { MEM- } \\
\text { Medium }\end{array}$ & $50 \mathrm{pmol}$ & - & $200 \mu \mathrm{l}$ & gefärbt \\
\hline 6.000 .000 & $1600 \mu \mathrm{l}$ & $\begin{array}{c}8 \mu \mathrm{l} \text { in } 100 \mu \mathrm{l} \\
\text { MEM- } \\
\text { Medium }\end{array}$ & - & $50 \mathrm{pmol}$ & $200 \mu \mathrm{l}$ & gefärbt \\
\hline
\end{tabular}

Da bei einer Transfektion mit $50 \mathrm{pmol} / \mathrm{ml}$ microRNA-Kontrolle oder microRNA-

Inhibitor 19b bei den humanen MNZ hohe Apoptoseraten messbar waren, wurde die Transfektion auch mit $25 \mathrm{pmol} / \mathrm{ml}$ (50 pmol/Ansatz) microRNA auf 6.000.000 humane Leukozyten durchgeführt wurde (Tab. 2.10).

\subsection{Transfektions- und Apoptoserate von Leukozytensubpopu- lationen}

Bei den humanen MNZ aus Buffy Coats handelt es sich um ein Gemisch aus verschiedenen Leukozytenarten. Es sollte daher ermittelt werden, ob sich die Transfektionsund Apoptoseraten bei den verschiedenen Leukozytensubpopulationen unterscheiden. Dazu wurden Monozyten mit einem CD14-Antikörper, T-Lymphozyten mit einem CD3- 
Antikörper und B-Lymphozyten mit einem CD19-Antikörper markiert. Zur Identifizierung der apoptotischen Monozyten, T-Lymphozyten und B-Lymphozyten erfolgte zusätzlich eine Färbung mit dem Annexin V-Antikörper und 7-Aminoactinomycin (7-AAD). Durch Annexin V werden alle apoptotischen Zellen, jedoch insbesondere schon frühapoptotische Zellen angefärbt. 7-AAD hingegen färbt spätapoptotische Zellen durch Interkalation mit DNA an. 7-AAD interagiert ausschließlich mit DNA von nicht-vitalen Zellen, da der Farbstoff nur in Zellen ohne intakte Zellmembran eindringen kann.

Für diese Untersuchung wurden erneut die Proben mit erhöhter Zellzahl gemäß der Beschreibung aus Abschnitt 2.11 hergestellt und inkubiert. Nach der zweitägigen Inkubation bei $37^{\circ} \mathrm{C}$ wurden die Proben jeweils in ein FACS-Röhrchen überführt und bei $400 \mathrm{~g}$ zentrifugiert. Der erhaltene Überstand wurde verworfen und das Zellpellett in 2 ml MACS-Puffer gelöst. Anschließend wurde eine erneute Zentrifugation bei den gleichen Bedingungen durchgeführt und der Überstand wiederum verworfen. Das Zellpellett der ungefärbten Kontrolle wurde in 300 pl MACS-Puffer gelöst und bis zum Ende der Färbung beiseite gestellt.

Für die Färbung der T-Lymphozyten wurden die Zellpellets der zu färbenden Proben mit erhöhter Zellzahl in je $100 \mu \mathrm{l}$ MACS-Puffer gelöst und je $1 \mu \mathrm{l}$ des CD3-Antikörpers hinzugefügt, gefolgt von einer zehnminütigen Inkubation unter Lichtausschluss. Anschließend wurden je 2 ml MACS-Puffer dazugegeben und die FACS-Röhrchen bei $400 \mathrm{~g}$ für acht Minuten zentrifugiert. Der Überstand wurde erneut verworfen und die Zellpellets in je 100 pl Annexin V-Puffer gelöst. Zu jedem FACS-Röhrchen wurden anschließend

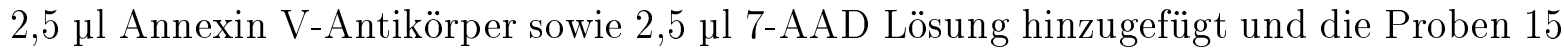
Minuten unter Lichtausschluss inkubiert. Danach wurde jedem FACS-Röhrchen $200 \mu$ l Annexin V-Puffer zugefügt und es erfolgte die Bestimmung der Apoptoserate von transfizierten und untransfizierten CD3 positiven Zellen sowie der Transfektionsrate per Durchflusszytometrie.

Analog zur Färbung von T-Lymphozyten erfolgte die Färbung der B-Lymphozyten, wobei anstelle von $1 \mu$ l CD3-Antikörper jeweils 2,5 $\mu$ l des CD19-Antikörpers verwendet 
wurden. Monozyten wurden mit 2,5 $\mathrm{pl}$ des CD14-Antikörpers gefärbt. Die abschließende Messung der Transfektions und Apoptoserate erfolgte erneut durchflusszytometrisch Abb. 2.3).

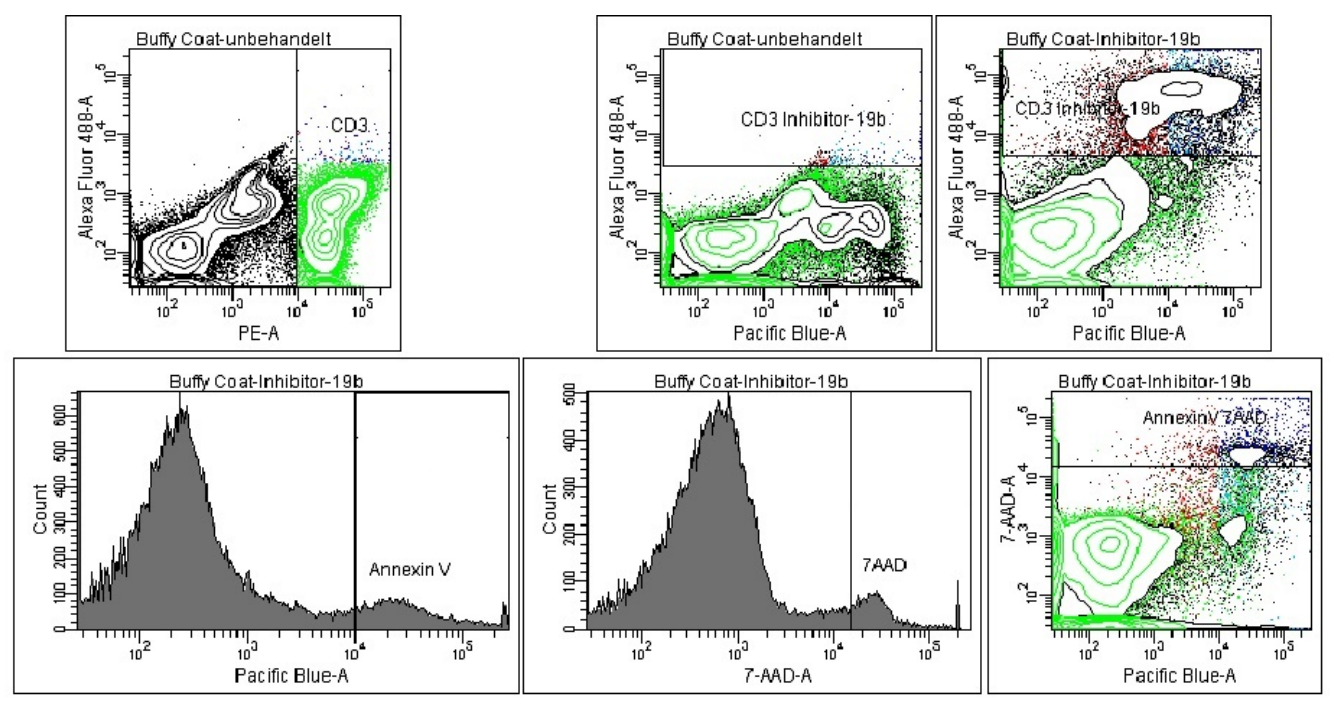

Abbildung 2.3: Bestimmung von Apoptose- und Transfektionsraten der verschiedenen Subpopulationen von humanen primären Leukozyten. Oben links: Eingrenzung des Anteils an PE-positiven Zellen mit dem gefärbten Oberflächenmerkmal (CD3-, CD14 oder CD19PE, hellgrün); oben mittig und rechts: Bestimmung der Transfektionsrate von allen PEpositiven Zellen als FITC-positive Zellen in der transfizierten Probe rechts im Vergleich zur unbehandelten Probe mittig; unten: Abgrenzung der Annexin V-Pacific Blue-positiven Zellen (türkis in der rechten Abbildung) von allen PE-positiven Zellen und Abgrenzung der PE-, Annexin V- und 7-AAD-positiven Zellen (dunkelblau in der rechten Abbildung) zunächst in den Einzeldarstellungen, die automatisch in die Gesamtdarstellung unten rechts übernommen wurden

Zunächst wurde der Anteil an Zellen mit dem angefärbten Oberflächenmerkmal (CD3, CD14 oder CD19-PE) eingegrenzt. Anschließend wurde von allen PE-positiven die FITCpositiven Zellen abgegrenzt. Hiefür diente der Vergleich von unbehandelten und transfizierten Proben. Anschließend wurde von allen PE-positiven Zellen der Anteil Annexin Vpositiver, 7-AAD-negativer sowie Annexin V- und 7-AAD-positiver Zellen ermittelt. 


\section{$3 \quad$ Ergebnisse}

\subsection{Transfektionsbedingungen bei Jurkat-Zellen}

Beim Vergleich der Transfektionsrate von Jurkat-Zellen bei unterschiedlicher Inkubationsdauer und Verwendung von verschiedenen Transfektionsreagenzien zeigten sich signifikante Unterschiede (ANOVA, $\mathrm{p}<0,001, \mathrm{Abb} .3 .1$ ). Die unterschiedlichen Inkubationsdauern ergaben keine signifikanten Unterschiede in der Transfektionsrate für den Vergleich von ein- und zweitägiger Inkubation (T-Test, $\mathrm{p}=0,46$ ), zwei- und dreitägiger Inkubation (T-Test, $\mathrm{p}=0,23)$ und ein- und dreitägiger Inkubation (T-Test, $\mathrm{p}=0,13)$ bei Verwendung von siLentFect (Abb. 3.1). Der Vergleich der verschiedenen Transfektionsreagenzien hingegen zeigte bei dreitägiger Inkubation signifikant höhere Transfektionsraten für siLentFect im Vergleich zu Lipofectamine (T-Test, $\mathrm{p}=0,007$ ) und zu HiPerfect (T-Test, $\mathrm{p}=0,003)$. Das Transfektionsreagenz siLentFect konnte somit als Transfektionsreagenz mit der höchsten Transfektionseffizienz bei Transfektion von 500.000 Jurkat-Zellen identifiziert werden (Abb.3.1). Die maximale Transfektionsrate lag bei Transfektion von 500.000 Jurkat-Zellen jedoch im Mittel nur bei 26,8\% ( $\mathrm{n}=3$ ). Daher wurde untersucht, ob durch Erhöhung der Konzentrationen von siLentFect oder microRNA höhere Transfektionsraten erzielt werden.

Bei Verwendung von 2,5 $\mu$ l siLentFect wurde mit 41,1\% die höchste Transfektionsrate beobachtet. Der Unterschied zu 1,5 pl (Transfektionsrate 26,8\%) und 4,0 $\mu$ l (Transfektionsrate 37,5\%) war jedoch nicht statistisch signifikant (ANOVA, p =0,32, Abb. 3.2). Aufgrund der tendenziell höheren Transfektionsrate von 41,1\% bei Transfektion mit 2,5 $\mu 1$ siLentFect wurde in den weiteren Versuchen diese Konzentration für das Transfektions- 


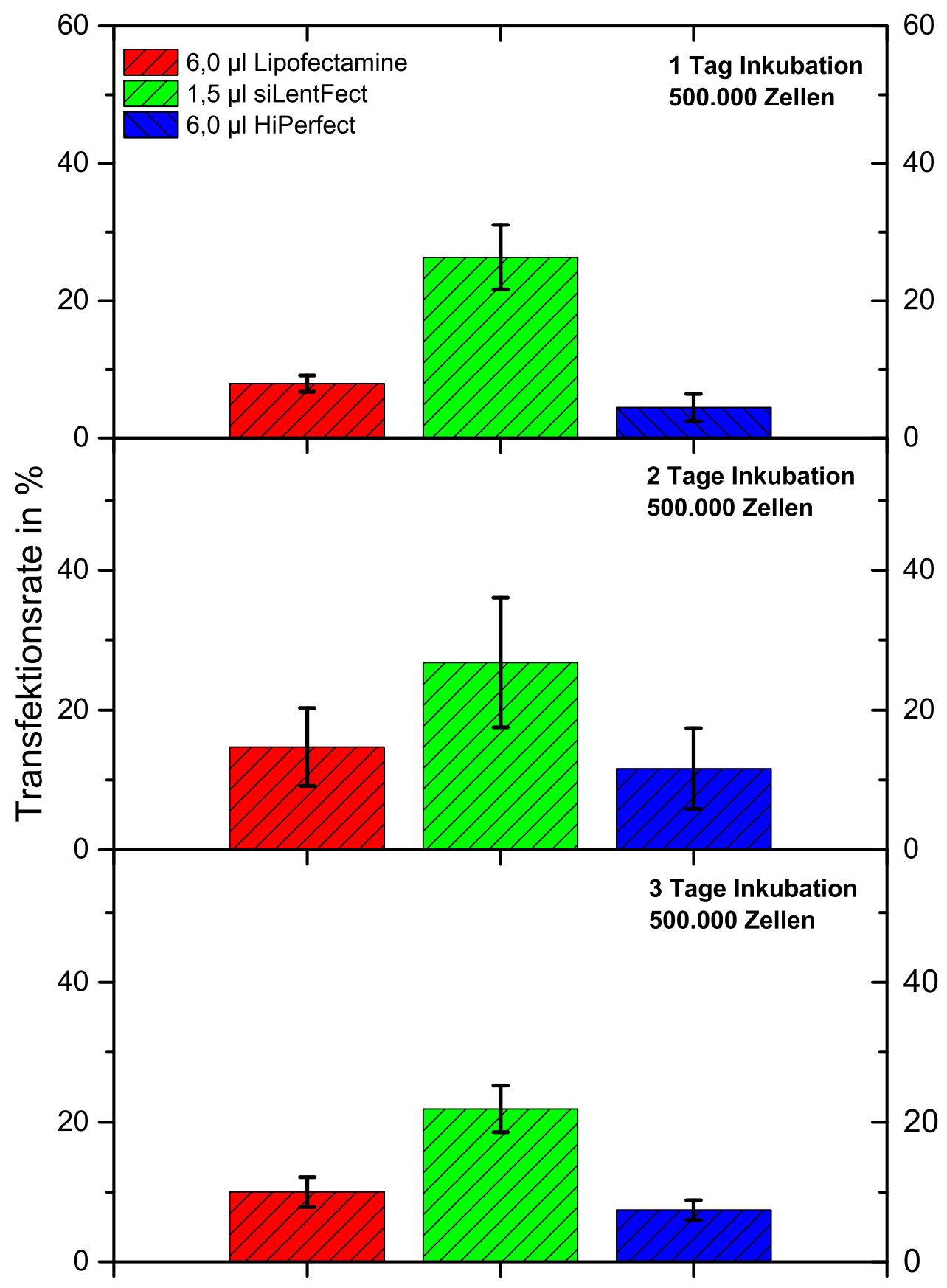

Abbildung 3.1: Vergleich der Transfektionsrate der Transfektionsreagenzien Lipofectamine (rot), siLentFect (grün) und HiPerfect (blau) bei Jurkat-Zellen für die Transfektion von $50 \mathrm{pmol} / \mathrm{ml}$ microRNA-Kontrolle. Die aufgeführten Messungen fanden nach ein, zwei und drei Tagen Inkubationszeit statt, die im oberen, mittleren und unteren Teil der Abbildung dargestellt sind $(\mathrm{n}=3, \overline{\mathrm{x}} \pm \mathrm{SD})$ 

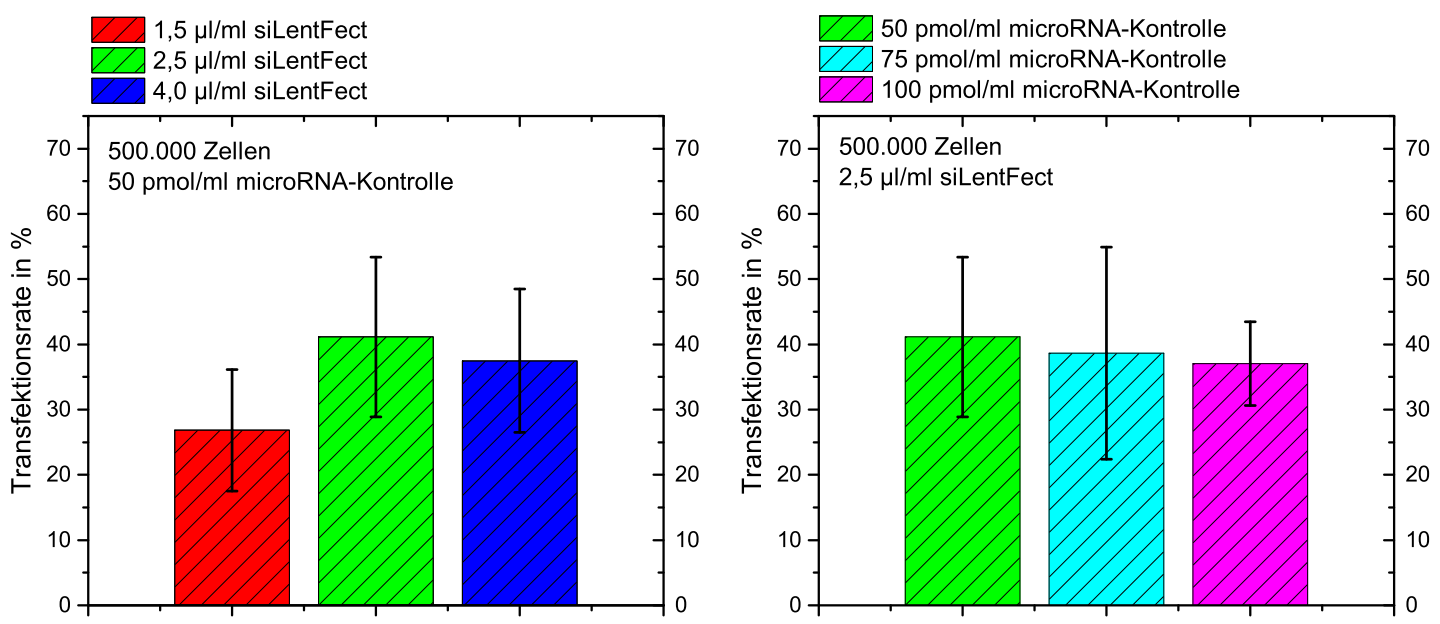

Abbildung 3.2: Bestimmung der Transfektionsraten von Jurkat-Zellen unter Verwendung von verschiedenen Konzentrationen Transfektionsreagenz siLentFect im linken Diagramm: $1,5 \mathrm{\mu l} / \mathrm{ml}$ (rot), $2,5 \mathrm{\mu l} / \mathrm{ml}$ (grün) und $4,0 \mu \mathrm{l} / \mathrm{ml}$ (blau) siLentFect. Transfektionsraten bei Verwendung von 2,5 $\mathrm{\mu l}$ siLentFect und unterschiedlichen Konzentrationen an microRNAKontrolle im rechten Diagramm: $50 \mathrm{pmol} / \mathrm{ml}$ ((grün) $75 \mathrm{pmol} / \mathrm{ml}$ und (türkis) $100 \mathrm{pmol} / \mathrm{ml}$ (violett) microRNA-Kontrolle $(\mathrm{n}=4, \overline{\mathrm{x}} \pm \mathrm{SD})$

reagenz verwendet. Durch Erhöhung der Konzentration an microRNA-Kontrolle wurde ebenfalls keine signifikante Erhöhung der Transfektionsrate erreicht (ANOVA, $\mathrm{p}=0,88$, Abb. 3.2). Daher wurde in den weiteren Versuchen die Konzentration von $50 \mathrm{pmol} / \mathrm{ml}$ microRNA-Kontrolle beibehalten.

Zusammenfassend lässt sich festhalten, dass mit 41,1\% die höchste Transfektionsrate von Jurkat-Zellen bei Verwendung von $2,5 \mathrm{\mu l} / \mathrm{ml}$ siLentFect und $50 \mathrm{pmol} / \mathrm{ml}$ microRNAKontrolle erzielt wurde. Diese Transfektionsbedingungen wurden für die Transfektion der Jurkat-Zellen mit dem microRNA-Inhibitor 19b verwendet.

\subsection{Transfektionsbedingungen bei SU-DHL-4-Zellen}

Um die Wirkung der microRNAs auch auf andere maligne Zelllinien zu testen, wurde zusätzlich die B-Zell-Lymphomlinie SU-DHL-4 untersucht. Zur Ermittlung der Transfektionsbedingungen mit der höchsten Transfektionsrate bei SU-DHL-4-Zellen wurden die Transfektionsreagenzien siLentFect und Lipofectamine bei zwei- und dreitägiger In- 
kubation unter Kultivierung der Zellen in verschiedenen Nährmedien getestet. Da die Verwendung des Transfektionsreagenzes HiPerfect bei den Jurkat-Zellen nur niedrige Transfektionsraten von maximal 11,6\% ergeben hatte, wurde es bei den SU-DHL-4-Zellen nicht untersucht.

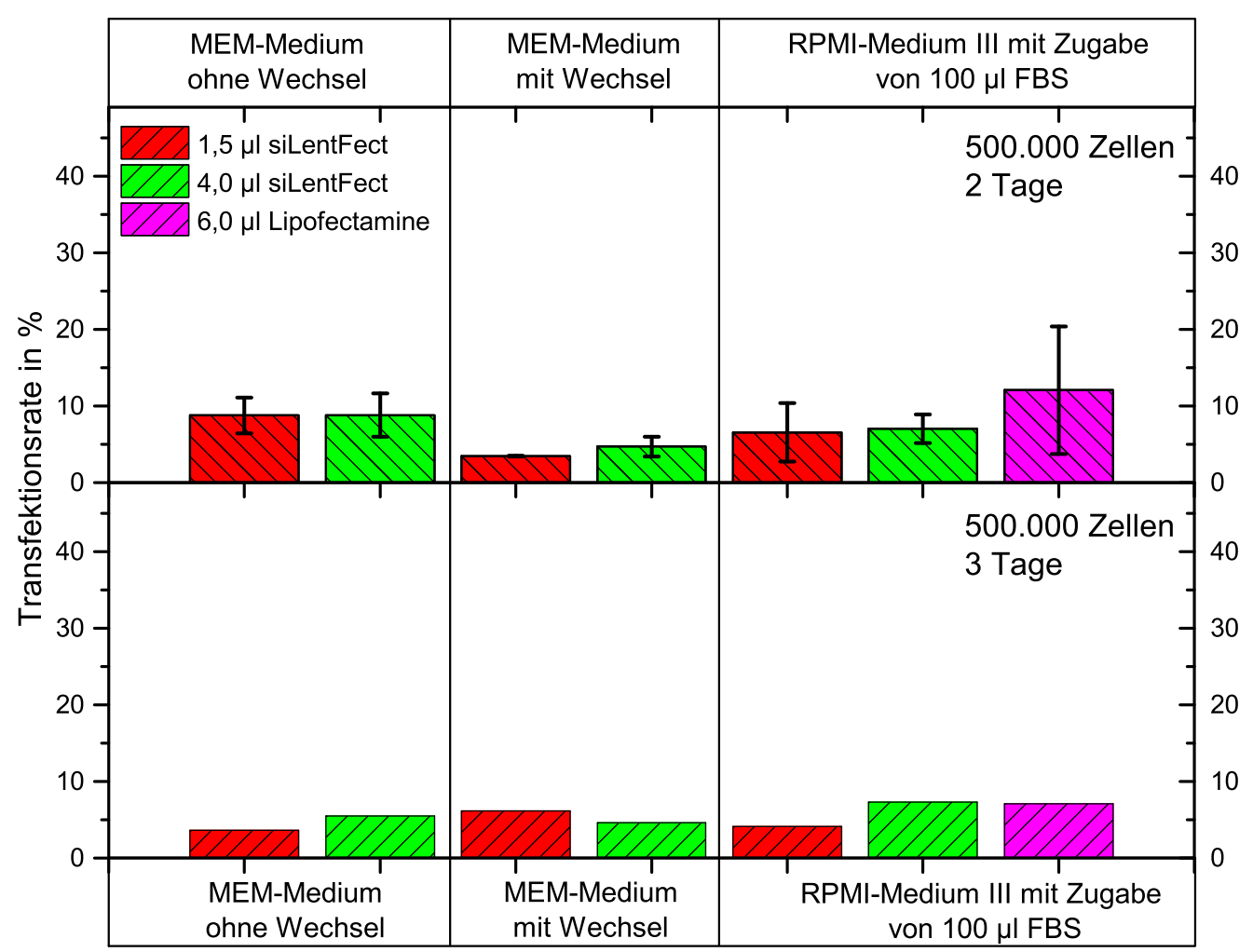

Abbildung 3.3: Testung der Transfektionsrate bei SU-DHL-4-Zellen mit den Transfektionsreagenzien siLentFect (in verschiedenen Konzentrationen, rot und grün) und Lipofectamine (violett) unter Verwendung von verschiedenen Nährmedien nach zwei- (oben) oder dreitägiger (unten) Inkubation $(\mathrm{n}=2-4, \overline{\mathrm{x}} \pm \mathrm{SD})$, aufgrund der geringen Probenanzahl von $\mathrm{n}=2$ wurden für die Proben mit dreitägiger Inkubation keine Standardabweichungen berechnet.

Die Transfektionsraten unter Verwendung von siLentFect und zweitägiger Inkubation waren bei Verwendung von verschiedenen Nährmedien und unterschiedlicher siLentFectKonzentration signifikant unterschiedlich (ANOVA, $\mathrm{p}=0$, 003, Abb. 3.3). Die Transfektionsraten lagen nur bei maximal 12,1\%. Dieser Prozentsatz ist für eine erfolgversprechende Transfektion mit signifikanten Effekten auf die Zellen nicht ausreichend.

Die längere Inkubationsdauer von drei Tagen ergab keine signifikanten Unterschiede 
der Transfektionsraten bei verschiedenen Nährmedien und unterschiedlicher Reagenzkonzentration (ANOVA, $\mathrm{p}=0,07, \mathrm{Abb}$. 3.3). Auch nach dreitägiger Inkubationszeit lag die Transfektionsrate mit maximal 7,3\% zu niedrig für Versuche mit dem microRNAInhibitor 19b. In RPMI-Medium III wurde zusätzlich zu siLentFect auch Lipofectamine als Transfektionsreagenz getestet. Hier waren keine signifikanten Unterschiede in der Transfektionsrate bei unterschiedlicher Inkubationsdauer oder verschiedenem Transfektionsreagenz messbar (ANOVA, $\mathrm{p}=0,12$, Abb. 3.3).

Insgesamt wurde unter keiner der getesteten Bedingungen eine für die weiteren Versuche ausreichende Transfektionsrate erreicht. Daher wurde bei SU-DHL-4-Zellen auf Versuche mit dem microRNA-Inhibitor $19 \mathrm{~b}$ verzichtet.

\subsection{Transfektionsbedingungen bei humanen mononukleären Zel- len}

Um zu testen, wie sich der microRNA-Inhibitor 19b auf humane Primärzellen auswirkt, wurden humane MNZ aus Buffy Coats untersucht. Zunächst sollten die Transfektionsbedingungen mit der höchsten Transfektionsrate für die humanen MNZ ermittelt werden.

Bei Transfektion der MNZ mit 1,5 pl siLentFect ergaben sich durch verschiedene Inkubationsdauern und unterschiedliche Nährmedien signifikante Unterschiede in der Transfektionsrate (ANOVA, $\mathrm{p}<0,001, \mathrm{Abb}$. 3.4). Die verschiedenen Inkubationsdauern führten bei Kultivierung der Zellen in MEM-Medium (T-Test, p = 0,049) zu signifikant höheren Transfektionsraten nach dreitägiger Inkubation. Die Transfektionsraten waren mit 5\% nach zwei Tagen Inkubation und 5,7\% nach drei Tagen jedoch nicht ausreichend für weitere Versuche. Bei Kultivierung der MNZ in RPMI-Medium waren hingegen bei unterschiedlicher Inkubationsdauern keine signifikanten Unterschiede in der Transfektionsrate zu beobachten (T-Test, $\mathrm{p}=0,25)$. Beim Vergleich der verschiedenen Nährmedien wurde durch die Kultivierung der Zellen in RPMI-Medium III (Transfektionsrate 13,6\%) eine signifikant höhere Transfektionsrate als bei Kultivierung in MEM-Medium (Trans- 


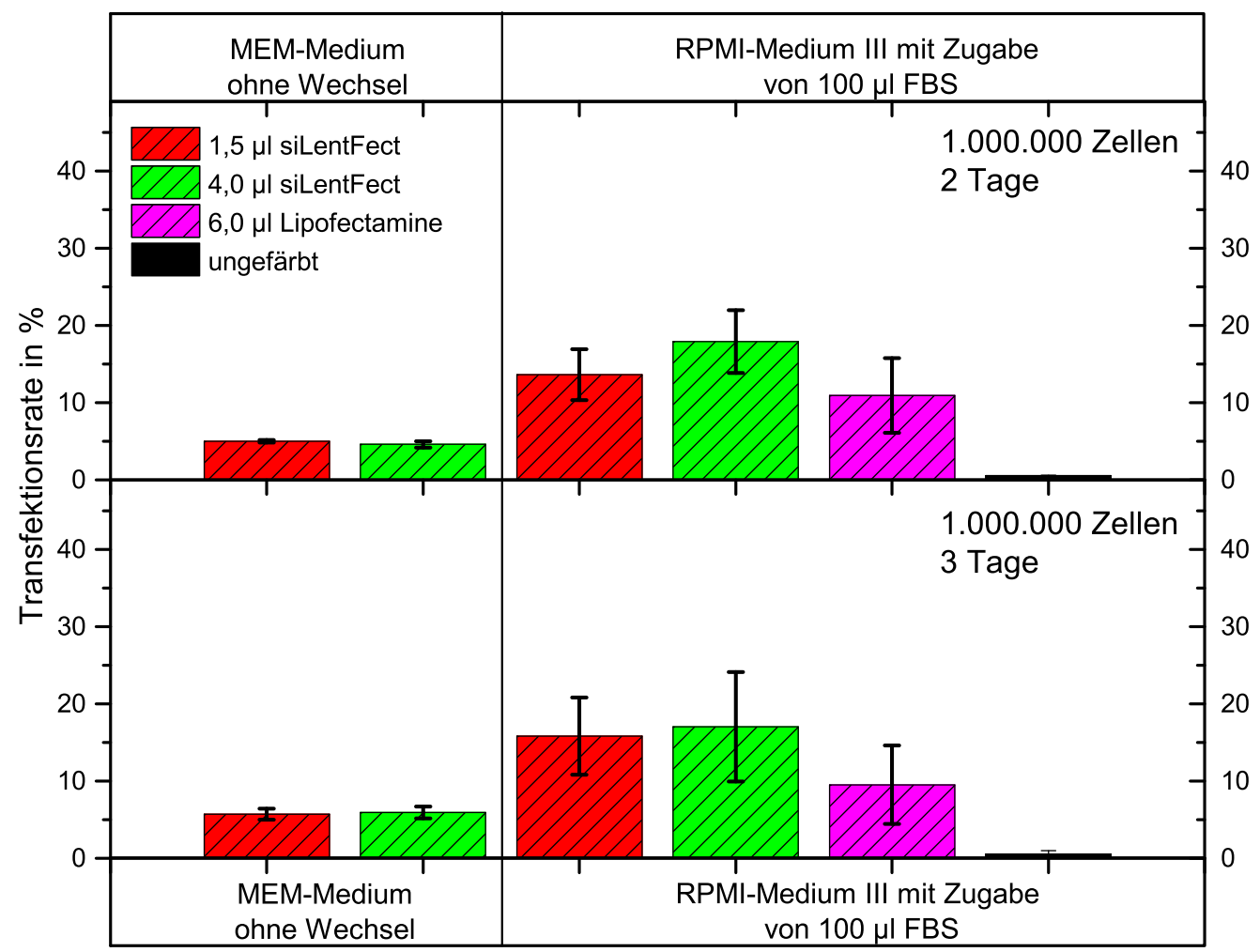

Abbildung 3.4: Vergleich der Transfektionsraten bei Transfektion von humanen MNZ aus BuffyCoats mit $50 \mathrm{pmol} / \mathrm{ml}$ microRNA-Kontrolle. Untersuchung des Einflusses von Nährmedien (MEM-Medium ohne Wechsel links, RPMI-Medium III mit Zugabe von 100 pl FBS am Folgetag rechts), Inkubationsdauer (2 oder 3 Tage, oben oder unten) und verschiedenen Transfektionsreagenzien (siLentFect in verschiedenen Konzentrationen, rot und grün; Lipofectamine, violett) auf die Transfektionsrate $(\mathrm{n}=4, \overline{\mathrm{x}} \pm \mathrm{SD})$

fektionsrate 5,0\%) gemessen (T-Test, $\mathrm{p}=0,007, \mathrm{Abb} .3 .4$ ). Daher wurden die MNZ in den weiteren Versuchen in RPMI-Medium III kultiviert. Unter Verwendung von RPMIMedium III zeigten sich signifikant unterschiedliche Transfektionsraten beim Einsatz von verschiedenen Transfektionsreagenzien (ANOVA, $\mathrm{p}=0,03, \mathrm{Abb} .3 .4$ ) und bei den unbehandelten MNZ eine unspezifische Reaktion von 0,5\%. Bei Transfektion mit 4,0 $\mathrm{\mu l} / \mathrm{ml}$ siLentFect ergab sich nach zweitägiger Inkubation eine signifikant höhere Transfektionsrate als bei Transfektion mit 6,0 $\mathrm{\mu l} / \mathrm{ml}$ Lipofectamine (T-Test, $\mathrm{p}=0,03)$. Der Vergleich der Transfektionsraten bei Verwendung von $1,5 \mu \mathrm{l} / \mathrm{ml}$ und $4,0 \mu \mathrm{l} / \mathrm{ml}$ siLentFect ergab hingegen keinen signifikanten Unterschied (T-Test, $\mathrm{p}=0,07$ ). Da die Transfektionsrate bei zweitägiger Inkubation bei Transfektion mit 4,0 $\mu \mathrm{l} / \mathrm{ml}$ siLentFect jedoch mit 17,9\% 
höher war als bei Transfektion mit 1,5 $\mathrm{ll}$ siLentFect (Transfektionsrate 13,6\%), wurde diese Konzentration an siLentFect für die weiteren Versuche verwendet.

Für die Transfektion mit dem microRNA-Inhibitor 19b wurden aufgrund dieser Ergebnisse MNZ in RPMI-Medium III inkubiert und mit 4,0 $\mathrm{ll} / \mathrm{ml}$ siLentFect versetzt.

\subsection{Transfektions- und Apoptoserate von Jurkat-Zellen bei Trans- fektion mit dem microRNA-Inhibitor $19 \mathrm{~b}$}

Für die Transfektionsraten der Jurkat-Zellen bei Transfektion mit microRNA-Kontrolle und microRNA-Inhibitor 19b und zwei- versus dreitägiger Inkubation ließen sich signifikante Unterschiede nachweisen (ANOVA, $\mathrm{p}=0,002$ ). Nach Anpassung des Signifikanzniveaus nach Bonferroni auf $\alpha<0,0125$ waren die Transfektionsraten bei Transfektion mit der microRNA-Kontrolle (Transfektionsrate 26,3\%) im Vergleich zum microRNAInhibitor 19b (Transfektionsrate 19,8\%) nach zwei Tagen Inkubation (T-Test, $\mathrm{p}=0,07$ ) nicht signifikant höher. Nach dreitägiger Inkubation ließen sich ebenfalls keine signifikanten Unterschiede in der Transfektionsrate von microRNA-Kontrolle (Transfektionsrate 19,4\%) und microRNA-Inhibitor 19b (Transfektionsrate 11,0\%) nachweisen (T-Test, $\mathrm{p}=0,02)$. Die Transfektionsrate der mit microRNA-Kontrolle transfizierten Zellen unterschied sich bei unterschiedlicher Inkubationsdauer von zwei oder drei Tagen nicht signifikant (T-Test, $\mathrm{p}=0,09$ ). Bei den mit microRNA-Inhibitor 19b transfizierten Zellen war die Transfektionsrate hingegen nach zweitägiger Inkubation mit 19,8\% signifikant höher als nach drei Tagen Inkubation mit 11,0\% (T-Test, $\mathrm{p}=0,002$ ).

Die Apoptoseraten von Jurkat-Zellen unterschieden sich in Abhängigkeit von unterschiedlichen Kulturbedingungen (ANOVA, $\mathrm{p}<0,001$, Abb. 3.5). Bei zweitägiger Inkubation war kein signifikanter Unterschied zwischen der unbehandelten Probe und der mit 2,5 $\mu \mathrm{l}$ siLentFect behandelten Probe nachweisbar (T-Test mit Anpassung des Signifikanzniveaus nach Bonferroni auf $\alpha<0,0125, \mathrm{p}=0,049$, Abb. 3.5). In den mit microRNA-Kontrolle transfizierten Zellen lag die Apoptoserate mit 15,2\% signifikant 


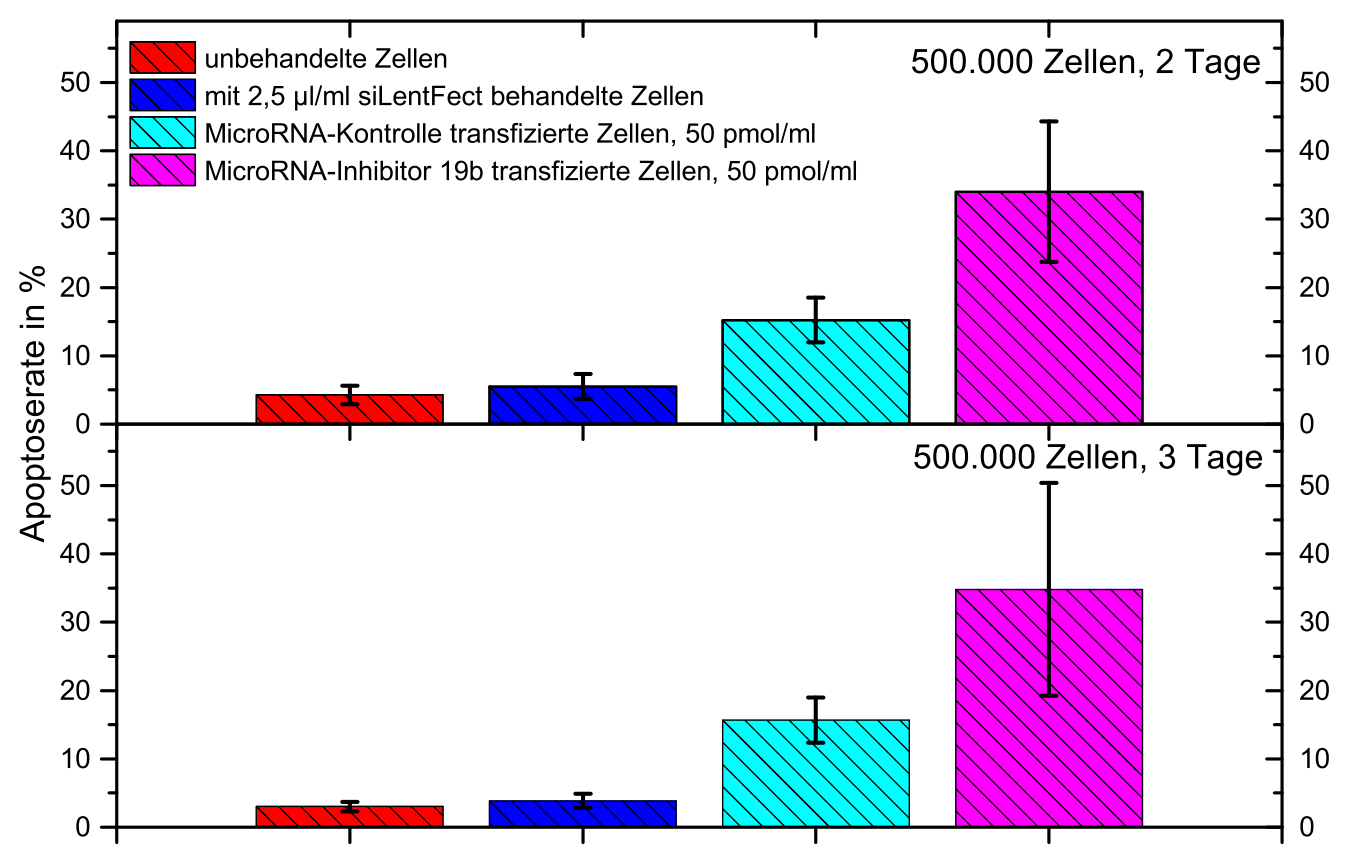

Abbildung 3.5: Apoptoseraten von Jurkat-Zellen in der unbehandelten Probe (rot), in der nur mit Transfektionsreagenz behandelten Probe (blau), in der mit microRNA-Kontrolle transfizierten Probe (türkis) und in der mit microRNA-Inhibitor 19b transfizierten Probe (violett) nach zwei- bzw. dreitägiger Inkubation (oberer bzw. unterer Teil der Abbildung, $\mathrm{n}=10, \overline{\mathrm{x}} \pm \mathrm{SD})$

über der Apoptoserate der unbehandelten Probe mit 4,3\% (T-Test, $\mathrm{p}<0,001$ ). Die Apoptoserate der nicht transfizierten Zellen in der mit microRNA-Kontrolle behandelten Probe lag bei 2,2\%. Bei den mit microRNA-Inhibitor 19b transfizierten Zellen zeigte sich mit 34,0\% ein signifikanter Anstieg der Apoptoserate auf das Sechsfache im Vergleich zu den unbehandelten Jurkat-Zellen (T-Test, $\mathrm{p}<0,001)$ und auf das Doppelte verglichen mit den mit microRNA-Kontrolle transfizierten Zellen (T-Test, p $<0,001$, Abb. 3.5). Die Apoptoserate der nicht transfizierten Zellen in der mit microRNA-Inhibitor 19b behandelten Probe lag bei 2,6\%.

Auch bei der längeren dreitägigen Inkubation zeigten die unbehandelten Jurkat-Zellen im Vergleich zu den mit 2,5 $\mathrm{ll}$ siLentFect behandelten Zellen nicht signifikant verschiedene Apoptoseraten (T-Test, $\mathrm{p}=0,06)$. Wurde die Apoptoserate der mit microRNA- 
Kontrolle transfizierten Zellen betrachtet, war eine Verfünffachung der Apoptoserate auf 15,7\% im Vergleich zu den unbehandelten Zellen mit 3,0\% (T-Test, p < 0,001) nachweisbar. Die Apoptoserate der nicht transfizierten Zellen in der mit microRNA-Kontrolle behandelten Zellen lag bei 1,5\%. Bei der Messung der Apoptoserate der mit microRNAInhibitor 19b transfizierten Zellen zeigte sich eine Verdoppelung der Apoptoserate auf $34,8 \%$ verglichen mit $15,7 \%$ bei den mit microRNA-Kontrolle transfizierten Zellen (TTest mit Anpassung des Signifikanzniveaus nach Bonferroni auf $\alpha<0,0125, \mathrm{p}=0,02$ ). Im Vergleich zu den unbehandelten Zellen konnte sogar eine Verachtfachung der Apoptoserate festgestellt werden (T-Test, $\mathrm{p}<0,001)$. Die Apoptoserate der untransfizierten Zellen lag in der mit microRNA-Inhibitor 19b behandelten Probe bei 1,7\%. Die Inkubationsdauer führte weder bei Transfektion mit der microRNA-Kontrolle (T-Test, $\mathrm{p}=0,37$ ) noch bei Transfektion mit dem microRNA-Inhibitor 19b zu signifikant verschiedenen Apoptoseraten (T-Test, $\mathrm{p}=0,37, \mathrm{Abb} .3 .5$ ).

Insgesamt führte der Einsatz des Transfektionsreagenzes siLent Fect alleine zu keiner signifikant höheren Apoptoserate im Vergleich zu den unbehandelten Jurkat-Zellen. Bei den mit microRNA-Kontrolle transfizierten Zellen kam es sowohl nach zwei- als auch nach dreitägiger Inkubation zu einem signifikanten Anstieg der Apoptoserate im Vergleich zur unbehandelten Probe. Bei Transfektion mit dem microRNA-Inhibitor 19b konnte sowohl nach zwei- als auch nach dreitägiger Inkubation ein signifikanter Anstieg der Apoptoserate der transfizierten Zellen im Vergleich zur unbehandelten Probe und zu den mit microRNA-Kontrolle transfizierten Zellen gezeigt werden. Eine Verlängerung der Inkubationsdauer von zwei auf drei Tage führte hingegen nicht zu signifikant unterschiedlichen Apoptoseraten. 


\title{
3.5 Transfektions- und Apoptoserate von humanen mononukle- ären Zellen bei Transfektion mit dem microRNA-Inhibitor $19 \mathrm{~b}$
}

Um eine erste Einschätzung zu erhalten, ob der Einsatz des microRNA-Inhibitors 19b bei humanen Primärzellen zu einer verstärkten Apoptoserate führt, wurden MNZ aus humanen Buffy Coats mit dem microRNA-Inhibitor 19b transfiziert.

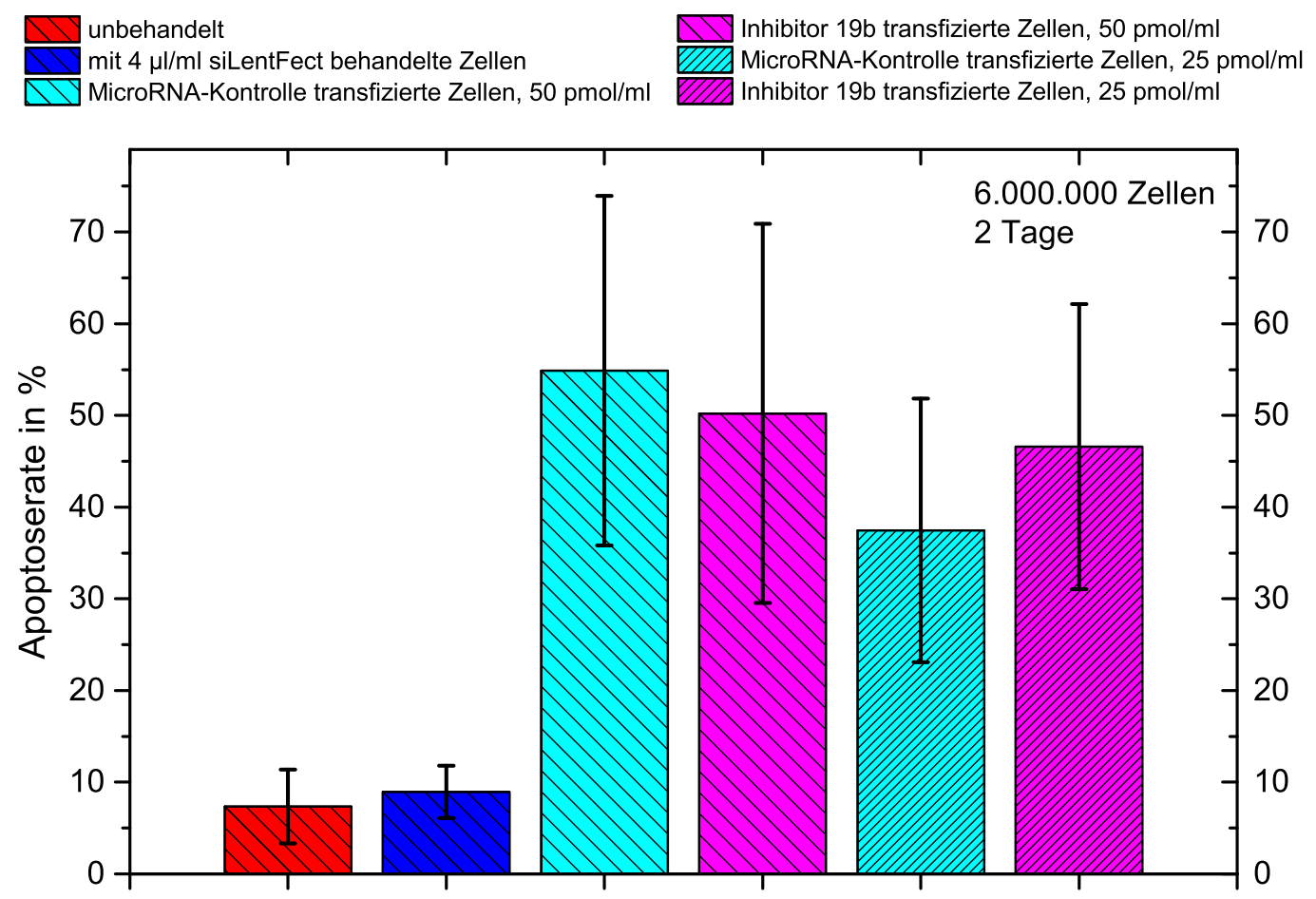

\begin{abstract}
Abbildung 3.6: Apoptoseraten von humanen MNZ in der unbehandelten Probe (rot), in der nur mit Transfektionsreagenz siLentFect behandelten Probe (blau), in der mit $50 \mathrm{pmol} / \mathrm{ml}$ microRNA-Kontrolle transfizierten Probe (türkis, breit gestreift), in der mit $50 \mathrm{pmol} / \mathrm{ml}$ microRNA-Inhibitor 19b transfizierten Probe (violett, breit gestreift), in der mit $25 \mathrm{pmol} / \mathrm{ml}$ microRNA-Kontrolle transfizierten Probe (türkis, eng gestreift) und in der mit $25 \mathrm{pmol} / \mathrm{ml}$ microRNA-Inhibitor 19b transfizierten Probe (violett, eng gestreift) nach zweitägiger Inkubation $(\mathrm{n}=10, \overline{\mathrm{x}} \pm \mathrm{SD})$
\end{abstract}

Bei Betrachtung der Apoptoseraten von MNZ in Abhängigkeit von unterschiedlichen Kulturbedingungen ergaben sich signifikante Unterschiede (ANOVA, p < 0,001, 
Abb. 3.6). Durch Behandlung mit dem Transfektionsreagenz siLentFect konnte mit einer Apoptoserate von 9,0\% kein signifikanter Unterschied im Vergleich zur unbehandelten Probe mit einer Apoptoserate von 7,4\% festgestellt werden (T-Test, $\mathrm{p}=0,16$ ). Die Transfektion mit dem microRNA-Inhibitor 19b zeigte, sowohl bei Transfektion mit $50 \mathrm{pmol} / \mathrm{ml}$ microRNA-Inhibitor 19b (Apoptoserate 50,2\%) (T-Test, p < 0,001) als auch bei Transfektion mit $25 \mathrm{pmol} / \mathrm{ml}$ microRNA-Inhibitor 19b (Apoptoserate 46,6\%) (TTest, $\mathrm{p}<0,001)$ eine signifikante Erhöhung der Apoptoserate der transfizierten Zellen im Vergleich mit den unbehandelten Zellen. Die unterschiedlichen Konzentrationen an microRNA-Inhibitor 19b führten jedoch zu nicht signifikant unterschiedlichen Apoptoseraten (T-Test, $\mathrm{p}=0,33$ ). Die Apoptoseraten der untransfizierten Zellen in den mit microRNA-Inhibitor 19b behandelten Proben lagen bei Einsatz von $50 \mathrm{pmol} / \mathrm{ml}$ microRNA-Inhibitor $19 \mathrm{~b}$ bei $1,4 \%$ und bei $25 \mathrm{pmol} / \mathrm{ml}$ bei $2,3 \%$. Auch die Transfektion mit der microRNA-Kontrolle führte zu einem signifikanten Anstieg der Apoptoserate im Vergleich zu den unbehandelten Zellen, sowohl bei den mit $50 \mathrm{pmol} / \mathrm{ml}$ microRNAKontrolle transfizierten Zellen (Apoptoserate 54,9\%) (T-Test, p < 0,001), als auch bei den mit $25 \mathrm{pmol} / \mathrm{ml}$ microRNA-Kontrolle transfizierten Zellen (Apoptoserate 37,5\%) (T-Test, $\mathrm{p}<0$, 001). Hierbei zeigte sich ebenfalls bei Transfektion mit $25 \mathrm{pmol} / \mathrm{ml}$ microRNA-Kontrolle mit 37,5\% eine nicht signifikant niedrigere Apoptoserate als bei Transfektion mit $50 \mathrm{pmol} / \mathrm{ml}$ microRNA-Kontrolle mit 54,9\% (T-Test mit Anpassung des Signifikanzniveaus nach Bonferroni auf $\alpha<0,006, \mathrm{p}=0,02)$. Die Apoptoseraten der untransfizierten Zellen in den mit microRNA-Kontrolle behandelten Ansätzen lag bei $50 \mathrm{pmol} / \mathrm{ml}$ microRNA bei 1,9\% und bei $25 \mathrm{pmol} / \mathrm{ml}$ bei 2,0\%. Beim Vergleich der Apoptoseraten nach Transfektion mit microRNA-Kontrolle und microRNA-Inhibitor 19b zeigten sich weder bei $50 \mathrm{pmol} / \mathrm{ml}$ microRNA(-Kontrolle oder - Inhibitor 19b) (T-Test, $\mathrm{p}=0,30$ ) noch bei der niedrigeren microRNA-Konzentration von $25 \mathrm{pmol} / \mathrm{ml}(\mathrm{p}=0,09)$ ein signifikanter Unterschied (Abb. 3.6). Auffallend waren die bei den transfizierten humanen MNZ insgesamt sehr hohen Apoptoseraten von ca. $50 \%$.

Neben der Apoptoserate wurde zusätzlich durchflusszytometrisch die Transfektions- 
rate der Proben bestimmt. Bei Transfektion von humanen MNZ mit der microRNAKontrolle und dem microRNA-Inhibitor 19b in unterschiedlichen Konzentrationen waren signifikant unterschiedliche Transfektionsraten nachweisbar (ANOVA, $\mathrm{p}=0,01$ ). Nach Anpassung des Signifikanzniveaus nach Bonferroni auf $\alpha<0,0125$ zeigte sich bei Verwendung von $50 \mathrm{pmol} / \mathrm{ml}$ microRNA-Kontrolle (Transfektionsrate 7,4\%) kein signifikanter Unterschied der Transfektionsrate verglichen mit Zellen, die mit $50 \mathrm{pmol} / \mathrm{ml}$ microRNAInhibitor 19b transfiziert worden waren (Transfektionsrate 9,1\%) (T-Test, p = 0,22). Bei der geringeren Konzentration von $25 \mathrm{pmol} / \mathrm{ml}$ microRNA-Kontrolle war hingegen mit 14,4\% eine signifikant höhere Transfektionsrate als bei Transfektion mit $25 \mathrm{pmol} / \mathrm{ml}$ microRNA-Inhibitor 19b (Transfektionsrate 9,1\%) nachweisbar (T-Test, $\mathrm{p}=0,01$ ). Verglich man die Transfektionsraten nach Transfektion mit den unterschiedlichen Konzentrationen an microRNA, so ergab sich für die microRNA-Kontrolle ein signifikant höhere Transfektionsrate bei Verwendung von $25 \mathrm{pmol} / \mathrm{ml}$ (Transfektionsrate 14,4\%) im Vergleich zu $50 \mathrm{pmol} / \mathrm{ml}$ (Transfektionsrate 7,4\%) (T-Test, $\mathrm{p}=0,003$ ), während für den microRNA-Inhibitor 19b konzentrationsunabhängig die Transfektionsrate nur 9,1\% betrug (T-Test, $\mathrm{p}=0,48)$.

\subsection{Transfektions- und Apoptoseraten von Leukozytensubpo- pulationen}

Die in Abschnitt 3.5 gemessenen Transfektions- und Apoptoseraten wurden von allen MNZ eines Buffy Coats, unabhängig von der Zellart, gemessen. Da es sich bei diesen Zellen jedoch um eine Mischung aus verschiedenen Leukozytenarten handelt, stellte sich die Frage, ob es bei verschiedenen Leukozytenarten (T-Lymphozyten, B-Lymphozyten und Monozyten) Unterschiede hinsichtlich Transfektions- und Apoptoserate gibt. Der Anteil an T-Lymphozyten in den Zellkulturen der MNZ lag bei 41,7\% ( $\mathrm{n}=10, \mathrm{SD}=8,0 \%$ ),

der Anteil an B-Lymphozyten bei 12,4\% (n=10, SD=4,6\%) und der Anteil an Monozyten bei $16,4 \%(\mathrm{n}=10, \mathrm{SD}=5,0 \%)$. 


\subsubsection{Transfektionsraten von T-Lymphozyten, B-Lymphozyten und Mono- zyten}
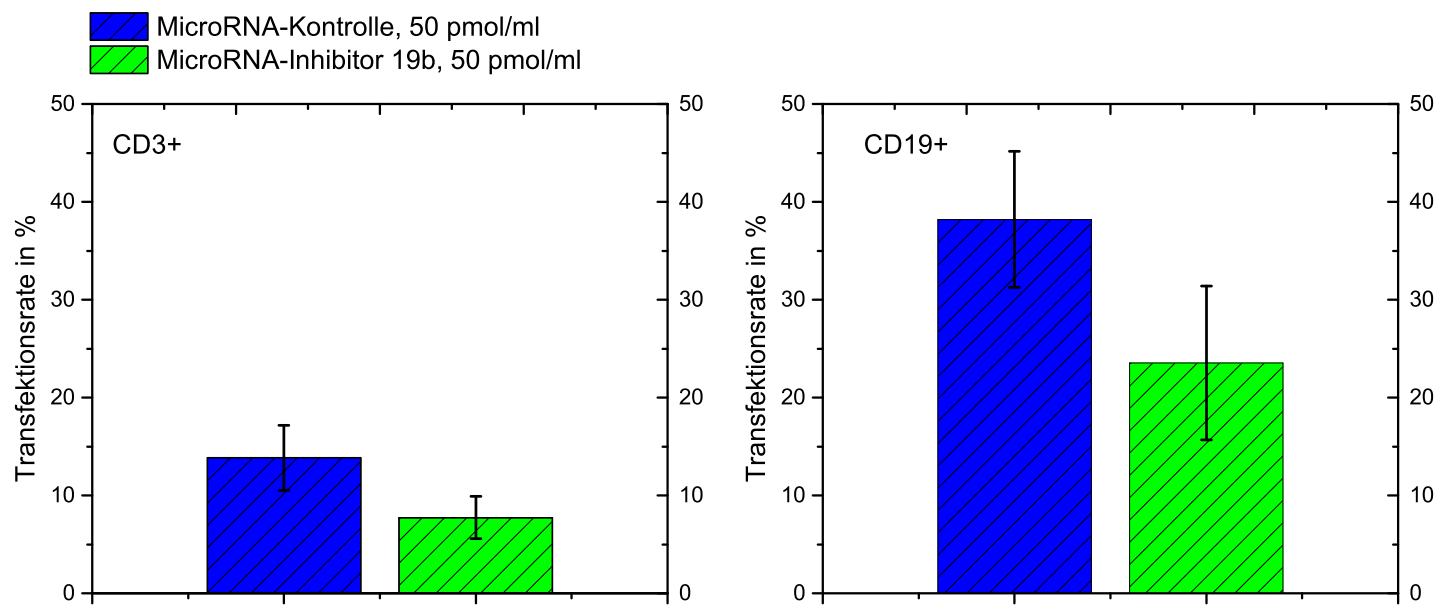

Abbildung 3.7: Vergleich der Transfektionsrate von T-Lymphozyten (linkes Diagramm) und B-Lymphozyten (rechtes Diagramm) in der mit microRNA-Kontrolle transfizierten Probe (blau) und der mit microRNA-Inhibitor 19b transfizierten Probe (grün) (n=10, $\overline{\mathrm{x}} \pm \mathrm{SD})$.

Monozyten waren in den transfizierten Proben durchflusszy tometrisch nicht nachweisbar, sodass für diese Leukozytenarte keine Transfektionsrate ermittelt werden konnte. Zwischen der Transfektionsrate von T- und B-Lymphozyten gab es signifikante Unterschiede (ANOVA, p < 0,001). Die Transfektionsrate der B-Lymphozyten lag bei Transfektion mit der microRNA-Kontrolle mit 38,2\% um den Faktor 2,8 höher als bei den TLymphozyten mit 13,8\% (T-Test, p < 0,001). Auch bei Transfektion mit dem microRNAInhibitor 19b war eine um den Faktor 2,6 höhere Transfektionsrate der B-Lymphozyten nachweisbar (T-Test, $\mathrm{p}<0,001)$. Bei Transfektion der T-Lymphozyten mit der microRNA-Kontrolle war mit 13,8\% eine signifikant höhere Transfektionsrate als bei Transfektion mit dem microRNA-Inhibitor $19 b$ mit 7,7\% nachweisbar (T-Test, $\mathrm{p}<0,001$, Abb. 3.7). Der Vergleich von B-Lymphozyten in der mit microRNA-Kontrolle transfizierten Probe ergab mit 38,2\% ebenfalls eine signifikant höhere Transfektionsrate als in der mit microRNA-Inhibitor 19b transfizierten Probe (23,5\%, T-Test, $\mathrm{p}<0,001)$. 


\subsubsection{Apoptoseraten von T-Lymphozyten, B-Lymphozyten und Monozyten}

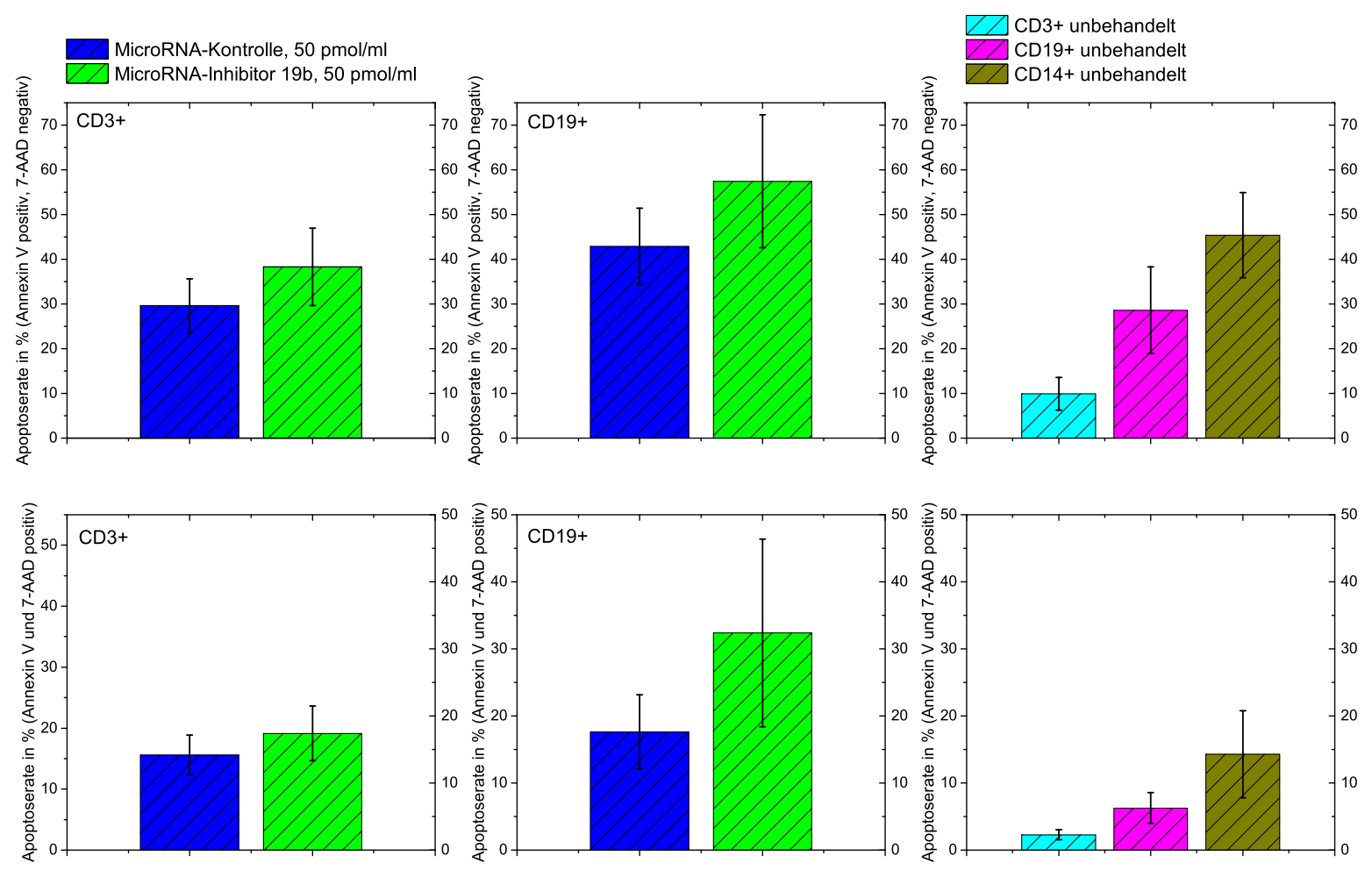

Abbildung 3.8: Anteil der Annexin V-positiven und 7-AAD-negativen Zellen in den oberen Diagrammen und der Annexin V- und 7-AAD-positiven Zellen in den unteren Diagrammen. Darstellung der mit microRNA-Kontrolle (blau) und microRNA-Inhibitor 19b (grün) transfizierten Zellen: T-Lymphozyten (links), B-Lymphozyten (mittig). Unbehandelten TLymphozyten, B-Lymphozyten und Monozyten in den rechten Diagrammen (türkis für T-Lymphozyten, violett für B-Lymphozyten, olive-grün für Monozyten) ( $\mathrm{n}=10, \overline{\mathrm{x}} \pm \mathrm{SD})$.

Neben den Transfektionsraten wurden die Apoptoseraten der verschiedenen Leukozytenarten gemessen. Für die mit microRNA-Kontrolle und microRNA-Inhibitor 19b transfizierten Proben sind in Abb. 3.8 die Apoptoseraten der nachweislich transfizierten Zellen dargestellt.

Der Anteil an Annexin V-positiven, 7-AAD-negativen und damit frühapoptotischen Zellen der unbehandelten Ansätze war je nach Leukozytenart signifikant verschieden (ANOVA, p < 0,001, Abb. 3.8) und wird im folgenden als Annexin V-positiver Anteil der Zellen bezeichnet. Der Anteil der frühapoptotischen Zellen lag bei den unbehandelten B-Lymphozyten (Apoptoserate 28,6\%) im Vergleich zu den T-Lymphozyten (Apoptose- 
rate 9,9\%) um den Faktor 3 signifikant höher (T-Test, $\mathrm{p}<0,001$ ). Die Apoptoserate der unbehandelten Monozyten lag mit 45,4\% noch einmal signifikant höher als bei den Lymphozyten (T-Test, p < 0,001, Abb. 3.8).

Nach Zugabe von microRNA waren keine Monozyten mehr in den Proben nachweisbar, sodass nur die Apoptoseraten von transfizierten T- und B-Lymphozyten dargestellt werden können (Abb. 3.8). Der Vergleich des Anteils an Annexin V-positiven T-Lymphozyten der unbehandelten Ansätze mit den Werten der transfizierten T-Lymphozyten ergab signifikante Unterschiede (ANOVA, $\mathrm{p}<0,001$ ). Nach Transfektion mit microRNA-Kontrolle ergab sich mit 29,6\% eine signifikant höhere Apoptoserate als bei den unbehandelten T-Lymphozyten mit 9,9\% (T-Test, $\mathrm{p}<0,001$ ). Auch bei den mit microRNA-Inhibitor 19b transfizierten T-Lymphozyten war mit 38,3\% ein signifikant höherer Anteil an Annexin V-positiven T-Lymphozyten mit einem Anstieg um den Faktor 3,9 im Vergleich zur unbehandelten Probe messbar (T-Test, $\mathrm{p}<0,001)$. Die Transfektion mit dem microRNA-Inhibitor 19b führte hierbei zu einem signifikant höheren Anteil an Annexin V-positiven T-Lymphozyten als die Transfektion mit der microRNAKontrolle (T-Test, $\mathrm{p}=$ 0,009, Abb. 3.8). Bei den B-Lymphozyten waren ähnliche Effekt wie bei den T-Lymphozyten erkennbar. Der Vergleich des Anteils an Annexin V-positiven B-Lymphozyten der unbehandelten Probe mit den Apoptoseraten der transfizierten BLymphozyten ergab hier ebenfalls signifikante Unterschiede (ANOVA, $\mathrm{p}<0,001$ ). Die mit microRNA-Kontrolle transfizierten B-Lymphozyten (Apoptoserate 42,9\%) zeigten, ebenso wie die mit microRNA-Inhibitor 19b transfizierten B-Lymphozyten (Apoptoserate 57,5\%), einen signifikant höhereren Anteil an Annexin V-positiven Zellen im Vergleich zur unbehandelten Probe mit 12,4\% (T-Test, $\mathrm{p}=$ 0, 001 für microRNA-Kontrolle, $\mathrm{p}<0,001$ für microRNA-Inhibitor 19b). Die Transfektion mit dem microRNA-Inhibitor 19b führte zu einem signifikant höheren Anteil an Annexin V-positiven B-Lymphozyten als die Transfektion mit der microRNA-Kontrolle (T-Test, $\mathrm{p}=$ 0, 009, Abb. 3.8). Beim direkten Vergleich zwischen T- und B-Lymphozyten zeigte sich in den mit microRNA-Kontrolle transfizierten Zellkulturen bei den B-Lymphozyten ein signifikant höherer Anteil an An- 
nexin V-positiven Zellen als bei den T-Lymphozyten (T-Test, $\mathrm{p}<0,001$ ). Auch in der mit microRNA-Inhibitor 19b transfizierten Probe zeigte sich bei B-Lymphozyten ein signifikant höherer Anteil an Annexin V-positiven Zellen als bei den T-Lymphozyten $(\mathrm{T}$-Test, $\mathrm{p}=0,002)$.

Außer dem Anteil an frühapoptotischen Zellen wurde auch der Anteil der Annexin Vund 7-AAD-positiven und damit spätapoptotischen Zellen bei den verschiedenen Leukozytenarten bestimmt, der im Folgenden als 7-AAD-positiv beschrieben wird. In der unbehandelten Probe wurden signifikant verschiedene Anteile an 7-AAD-positiven Zellen für die verschiedenen Leukozytenarten festgestellt (ANOVA, p < 0,001, Abb. 3.8). Der Anteil der spätapoptotischen Zellen lag bei den unbehandelten B-Lymphozyten (Apoptoserate 6,3\%) im Vergleich zu den T-Lymphozyten (Apoptoserate 2,3\%) signifikant höher (T-Test, $\mathrm{p}<0,001)$. Die Apoptoserate der unbehandelten Monozyten lag mit 14,3\% noch einmal signifikant höher als bei den T-Lymphozyten (T-Test, p < 0,001) und B-Lymphozyten (T-Test, $\mathrm{p}=0,002$ ). Für die Monozyten konnte nach Transfektion durchflusszytometrisch keine Population nachgewiesen werden. Zwischen unbehandelten und transfizierten Proben konnten signifikante Unterschiede beim Anteil an 7-AADpositiven T-Lymphozyten ermittelt werden (ANOVA, p < 0,001, Abb. 3.8). Im Vergleich zur unbehandelten Probe konnte ein signifikanter Anstieg des Anteils an 7-AADpositiven T-Lymphozyten bei Transfektion mit der microRNA-Kontrolle um den Faktor 6,8 auf 15,6\% nachgewiesen werden (T-Test, $\mathrm{p}<0,001$ ). Bei Transfektion mit dem microRNA-Inhibitor 19b war ein signifikanter Anstieg des Anteils an 7-AAD-positiven T-Lymphozyten um den Faktor 8,3 auf 19,1\% messbar (T-Test, p < 0,001). Nicht signifikant höher war hingegen der Anteil an 7-AAD-positiven T-Lymphozyten nach Zugabe von microRNA-Inhibitor 19b im Vergleich zur microRNA-Kontrolle (T-Test mit Anpassung des Signifikanzniveaus nach Bonferroni auf $\alpha<0,017, \mathrm{p}=0,03)$. Bei den BLymphozyten waren ebenfalls signifikante Unterschiede im Anteil der 7-AAD-positiven B-Lymphozyten der unbehandelten und transfizierten Proben nachweisbar (ANOVA, p $<0,001$, Abb. 3.8). Der Anteil an 7-AAD-positiven B-Lymphozyten war bei Transfek- 
tion mit der microRNA-Kontrolle mit 17,6\% um den Faktor 2,8 höher als in der unbehandelten Probe (T-Test, p < 0,001). Ebenso war bei Transfektion mit dem microRNAInhibitor 19b mit 32,4\% ein um den Faktor 5,0 höherer Anteil an 7-AAD-positiven B-Lymphozyten messbar (T-Test, $\mathrm{p}<0,001$ ). Auch beim Vergleich von Transfektion mit microRNA-Kontrolle und microRNA-Inhibitor 19b ergab sich ein signifikant höherer Anteil an spätapoptotischen B-Lymphozyten bei Transfektion mit dem microRNAInhibitor 19b (T-Test, $\mathrm{p}=0,006)$. Der direkte Vergleich von transfizierten T- und BLymphozyten zeigte signifikant verschiedene Anteile an 7-AAD-positiven Zellen (ANOVA, p < 0,001, Abb. 3.8). Für die Transfektion mit der microRNA-Kontrolle war für Tund B-Lymphozyten kein signifikanter Unterschied in der Apoptoserate messbar (T-Test, $\mathrm{p}=0,17)$. Bei den mit microRNA-Inhibitor 19b transfizierten Zellen ließ sich hingegen bei den B-Lymphozyten ein signifikant höherer Anteil an 7-AAD-positiven Zellen nachweisen als bei den T-Lymphozyten (T-Test, $\mathrm{p}=0,006)$.

Fasst man zusammen, so waren bei der Bestimmung des Anteils an früh- und spätapoptotischen Zellen die gleichen Tendenzen erkennbar. Monozyten zeigten in der unbehandelten Probe jeweils die höchste und T-Lymphozyten die geringste Apoptoserate. B-Lymphozyten zeigten insgesamt höhere Apoptoseraten (sowohl früh- als auch spätapoptotisch) als T-Lymphozyten, sowohl bei Transfektion mit dem microRNA-Inhibitor 19b als auch bei Transfektion mit der microRNA-Kontrolle. Die Apoptoseraten nach Transfektion mit dem microRNA-Inhibitor 19b waren bei T- und B-Lymphozyten höher als bei Transfektion mit der microRNA-Kontrolle. 


\section{Diskussion}

\subsection{Transfektionsbedingungen}

Ziel dieser Arbeit war die Induktion der Apoptose in malignen hyperplastischen Zellen mit Hilfe des microRNA-Inhibitors 19b. Die microRNA-19b gehört zum microRNACluster 17-92, das bei vielen Krebserkrankungen überexprimiert ist und zu einer verstärkten Proliferation und einer geringeren Apoptoserate von Zellen führt. Die microRNA-19 scheint hier eine Hauptrolle in der Funktion des genannten Clusters zu spielen, sodass durch Transfektion von Zellen mit einem microRNA-Inhibitor 19b ein Anstieg der Apoptoserate dieser Zellen angenommen wurde. Zur Testung dieser Hypothese wurden zwei humane Zelllinien sowie humane MNZ von gesunden Blutspendern untersucht.

\subsubsection{Transfektionsbedingungen bei Jurkat- und SU-DHL-4-Zellen}

Um eine therapeutisch wirksame intrazelluläre Konzentration des microRNA-Inhibitors 19b zu erreichen, wurden zunächst die optimalen Transfektionsbedingungen für die TZelllinie Jurkat und die B-Zelllinie SU-DHL-4 ermittelt.

Bei Jurkat-Zellen gab es bei den verschiedenen liposomalen Transfektionsreagenzien Lipofectamine, HiPerfect und siLentFect signifikante Unterschiede bei der Transfektionsrate. Die höchste Transfektionsrate von $26,8 \%$ konnte zunächst mit $1,5 \mu \mathrm{l} / \mathrm{ml}$ siLentFect nach zweitägiger Inkubation erreicht werden. Von anderen Autoren wurden Transfektionsraten von 40 bis $60 \%$ für Jurkat-Zellen genannt. Huang et al. (2016) beschrieben bei Transfektion von Jurkat-Zellen mittels 2,5-6,25 $\mathrm{\mu l} / \mathrm{ml}$ Lipofectamine eine Transfektionsrate von etwa $60 \%$, die fluoreszenzmikroskopisch bestimmt wurde. Von Alizadeh et al. 
(2014) wurde ebenfalls eine erfolgreiche Transfektion von Jurkat-Zellen mit 1,7 $\mathrm{\mu l} / \mathrm{ml}$ Lipofectamine beschrieben, wobei keine Transfektionsrate angegeben wurde. In der $\mathrm{Pu}-$ blikation von Chettab et al. (2015) wurden mit Lipofectamine nur Transfektionsraten von unter 1\% erreicht. Eine erfolgreiche Transfektion wurde in dieser Publikation hingegen mit Sonoporation (Transfektionsrate 42\%) und Elektroporation (Transfektionsrate 40\%) erreicht. Nach der vorliegenden Literatur schien es also möglich zu sein, eine höhere Transfektionsrate als 26,8\% bei Jurkat-Zellen zu erreichen. Diese Optimierung der Transfektion wurde in der vorliegenden Arbeit durch Verwendung von höheren siLentFectKonzentrationen $(4,0 \mu \mathrm{l} / \mathrm{ml}$ und $2,5 \mu \mathrm{l} / \mathrm{ml}$ statt $1,5 \mu \mathrm{l} / \mathrm{ml})$ und durch höhere microRNAKonzentrationen versucht. Signifikante Unterschiede ergaben sich hierbei nicht, jedoch war die mittlere Transfektionsrate bei Verwendung von 2,5 $\mu \mathrm{l} / \mathrm{ml}$ siLentFect mit $41 \%$ höher als bei Transfektion mit 4,0 $\mu \mathrm{l} / \mathrm{ml}$ oder 1,5 $\mu \mathrm{l} / \mathrm{ml}$ siLentFect. Die Konzentration von $2,5 \mathrm{\mu l} / \mathrm{ml}$ siLentFect wurde daher für die Transfektion von Jurkat-Zellen mit dem microRNA-Inhibitor 19b verwendet.

Bei verschiedenen Inkubationsdauern von ein bis drei Tagen zeigte sich bei JurkatZellen kein signifikanter Unterschied in der Transfektionsrate. Zu dieser Beobachtung lagen keine Vergleichsdaten in der Literatur vor, da in den meisten Publikationen kein Zeitpunkt der Bestimmung der Transfektionsrate angegeben wird. Lediglich Chettab et al. (2015) beschrieben, dass die liposomale Transfektion nicht möglich war, da die Transfektionsrate nach 24 Stunden niedrig war.

Um den Effekt des microRNA-Inhibitors 19b auch bei B-Lymphozyten zu untersuchen, wurde die B-Zell-Lymphomlinie SU-DHL-4 ausgewählt. Es waren unter Verwendung von verschiedenen liposomalen Transfektionsreagenzien, unterschiedlichen Nährmedien und variierender Inkubationsdauer insgesamt Transfektionsraten von maximal 12\% messbar, was für die geplante Untersuchung der Transfektion mit dem microRNAInhibitors 19b nicht ausreichend erschien. Von anderen Autoren ist eine erfolgreiche Transfektion der SU-DHL-4-Zellen beschrieben worden. So etablierten Schachtschabel et al. (1996) eine rezeptorvermittelte Endozytose von DNA, während von Inomata et al. 
(2009) die Transfektion von microRNAs in SU-DHL-4-Zellen mittels lentiviralen Vektoren durchgeführt wurde. Eine Angabe der Transfektionsrate fand sich bei beiden Autoren nicht. In der Literatur wurde hingegen keine erfolgreiche liposomale Transfektion von SU-DHL-4-Zellen beschrieben. Diese Transfektionsmethode scheint nach den vorliegenden Ergebnissen für SU-DHL-4-Zellen nicht geeignet zu sein, sodass für die Untersuchung des Effekts des microRNA-Inhibitors 19b auf maligne B-Lymphozyten entweder eine andere B-Zelllinie oder für SU-DHL-4-Zellen ein anderer Transfektionsmodus ausgewählt werden müsste.

\subsubsection{Transfektionsbedingungen bei humanen mononukleären Zellen}

Um den Effekt des microRNA-Inhibitors 19b auf humane Primärzellen zu untersuchen, wurden humane MNZ aus Buffy Coats transfiziert. Für die Transfektion von microRNAs wurde von verschiedenen Autoren die Elektroporation erfolgreich eingesetzt (Ho et al. 2013; Tano et al. 2011). Zudem war die Transfektion mittels Dendrimeren (PedziwiatrWerbicka et al. 2013) oder Lentiviren (Shimizu et al. 2016; Xu et al. 2014) erfolgreich. Die Transfektionsraten wurden in der vorliegenden Literatur jedoch nicht genannt. Am häufigsten wurden liposomale Transfektionsreagenzien eingesetzt. Verwendet wurden unter anderem Oligofectamine (Singh et al. 2014), siPORT Lipid Transfection Agent (Unlu et al. 2012) und Lipofectamine (Majumdar et al. 2014; Zheng et al. 2015; Nakasa et al. 2011, Guo et al. 2010). Zur Bestimmung der höchsten Transfektionseffizienz wurden in dieser Arbeit die Transfektionsraten bei Transfektion mit siLentFect und Lipofectamine in unterschiedlichen Nährmedien und mit verschiedener Inkubationsdauer getestet. Durch Verlängerung der Inkubationsdauer von zwei auf drei Tage konnte keine signifikante Veränderung der Transfektionsrate festgestellt werden. Dies wurde auch von Majumdar et al. (2014) beschrieben, die die Transfektionsrate nach Transfektion mit Lipofectamine und 60 pmol microRNA mit 23,7\% nach 18 Stunden und 22,2\% nach 36 Stunden angaben. Signifikante Unterschiede bei der Transfektionsrate wurden hingegen bei Kultivierung der Zellen in unterschiedlichen Nährmedien und bei den verschiedenen 
Transfektionsreagenzien festgestellt. Bei Transfektion der humanen primären Leukozyten in RPMI-Medium III unter Verwendung von $4,0 \mu \mathrm{l} / \mathrm{ml}$ siLentFect wurde mit $17 \%$ die höchste Transfektionsrate erzielt.

\subsection{Effekt des microRNA-Inhibitors $19 \mathrm{~b}$}

Ziel dieser Arbeit war die Untersuchung, ob durch Transfektion mit einem microRNAInhibitor die Apoptoserate von Zellen erhöht werden kann. Ausgewählt wurde hierfür der microRNA-Inhibitor 19b. Durch Matsubara et al. (2007) wurde bereits für alle microRNAs des microRNA-Clusters 17-92 eine Reduktion der microRNA-Konzentration durch Einbringen von antisense-Oligonukleotiden in Zelllinien gezeigt. In dieser Arbeit sollte nun evaluiert werden, ob durch Einbringen des microRNA-Inhibitors 19b und die daraus resultierende Reduktion der aktiven microRNA-Konzentration von miR-19b in den Zellen eine erhöhte Apoptoserate nachweisbar ist. Diese Untersuchung sollte an der T-ALLZelllinie Jurkat durchgeführt werden, um eine mögliche Therapie einer akuten Leukämie mit dem microRNA-Inhibitor $19 \mathrm{~b}$ zu testen. Um die Auswirkungen einer Transfektion mit dem microRNA-Inhibitor 19b darüber hinaus auch auf humane Primärzellen zu untersuchen, wurden neben den Jurkat-Zellen auch humane MNZ transfiziert.

\subsubsection{Auswirkungen der Transfektion mit dem microRNA-Inhibitor 19b auf Jurkat-Zellen}

Der Vergleich der Apoptoseraten (Anteil der Annexin V-positiven Zellen in der Durchflusszytometrie) von unbehandelten Zellen mit siLentFect-behandelten Jurkat-Zellen ergab keinen signifikanten Anstieg der Apoptoserate, sodass durch das Transfektionsreagenz alleine keine toxische Wirkung auf die Jurkat-Zellen nachgewiesen werden konnte. Bei Transfektion von Jurkat-Zellen mit der microRNA-Kontrolle kam es hingegen zu einem signifikanten Anstieg der Apoptoserate der transfizierten Zellen auf 15\% im Vergleich zu den unbehandelten Zellen (4,3\%). Daher schien bereits die Einschleusung einer 
microRNA ohne bekannte inhibitorische Funktion eine toxische Wirkung auf JurkatZellen zu haben. Von Li et al. (2013) wurde bei Transfektion von Jurkat-Zellen mit miR-99a und miR-100 für die verwendete microRNA-Kontrolle durchflusszytometrisch ein Anteil von Annexin V- und PI-positiven Zellen von 34\% und damit eine erheblich höhere Apoptoserate als in der vorliegenden Arbeit gemessen. Eine unbehandelte Zellkultur wurde nicht als Vergleich gemessen. Von Alizadeh et al. (2014) wurde für unbehandelte Jurkat-Zellen sowie eine microRNA-Kontrolle ohne inhibitorische Funktion eine gleich hohe Caspase-3-Aktivität sowie eine gleich hohe Vitalität im MTT-Test gemessen. Auch von Huang et al. (2016) wurde durchflusszytometrisch ein gleich bleibender Anteil an Annexin V- und 7-AAD-positiven Zellen bei unbehandelten und mit einer microRNAKontrolle transfizierten Zellen von etwa 14\% gemessen. Von beiden Autoren wurde jedoch die Apoptoserate aller Zellen in den Proben bestimmt, egal ob sie transfiziert oder nicht transfiziert waren. In der vorliegenden Arbeit wurde hingegen die Apoposerate der durchflusszytometrisch nachweislich mit microRNA(-Kontrolle oder -Inhibitor 19b) transfizierten Zellen bestimmt, wodurch die unterschiedlichen Ergebnisse beim Vergleich von unbehandelter und mit microRNA-Kontrolle behandelter Probe zu erklären sind.

Der Einsatz des microRNA-Inhibitors 19b hatte in der vorliegenden Arbeit eine signifikante Steigerung der Apoptoserate im Vergleich zur Transfektion mit der microRNAKontrolle zur Folge. So führte die Transfektion des microRNA-Inhibitors 19b zu einer Erhöhung der Apoptoserate der transfizierten Jurkat-Zellen auf 34\% im Vergleich zu 15\% bei Transfektion mit der microRNA-Kontrolle. Eine Reduktion der Zellvitalität konnte mittels MTT-Test von Alizadeh et al. (2014) entsprechend für miR-155 gezeigt werden.

Die Apoptoserate der untransfizierten Zellen in den mit microRNA-Kontrolle behandelten Ansätzen lag mit 2,2\% signifikant niedriger als in der unbehandelten Probe mit 4,3\%. Ebenso lag die Apoptoserate der untransfizierten Zellen in der mit microRNAInhibitor 19b behandelten Probe bei 2,6\%. Hier wäre einerseits ein systematischer Fehler durch ungenaue durchflusszytometrische Abgrenzung der verschiedenen Populationen in der Dreifachfärbung als Ursache denkbar. Andererseits wäre es möglich, dass microRNAs 
leichter in geschädigte, spontan apoptotische Zellen als in gesunde Zellen aufgenommen werden, sodass die Apoptoserate der in den Proben untransfizierten Zellen niedriger ist, da die gesunden Zellen untransfiziert bleiben.

Auch ein Einfluss der Inkubationsdauer der Transfektion auf die Apoptoserate wurde untersucht. Die Vermutung, dass die Erhöhung der Inkubationsdauer von zwei auf drei Tage zu einer Erhöhung der Apoptoserate führt, konnte aufgrund von annähernd gleichen Apoptoseraten nach zwei- und dreitägiger Inkubation nicht bestätigt werden. Von Li et al. (2013) wurde hingegen mittels Cell Counting Kit 8 eine signifikant höhere Apoptoserate nach dreitägiger als nach zweitägiger Inkubation beschrieben.

\subsubsection{Auswirkungen der Transfektion mit dem microRNA-Inhibitor 19b auf humane mononukleäre Zellen}

Nachdem bei der Jurkat-Zelllinie eine Erhöhung der Apoptoserate durch den microRNAInhibitor 19b gezeigt werden konnte, wurde untersucht, wie sich die Transfektion mit dem microRNA-Inhibitor 19b auf humane Primärzellen auswirkt.

Durch Behandlung von humanen mononukleären Zellen mit dem Transfektionsreagenz siLentFect alleine kam es mit 9,0\% zu einer geringen, aber nicht statistisch signifikanten Erhöhung der Apoptoserate im Vergleich zu unbehandelten Zellen mit 7,4\%. Wurden die Apoptoseraten der transfizierten MNZ betrachtet, waren bei Transfektion mit der microRNA-Kontrolle und mit microRNA-Inhibitor 19b im Vergleich zu unbehandelten Zellen erhöhte Apoptoseraten der transfizierten MNZ von bis zu $55 \%$ messbar. Dies war sowohl für die höheren Konzentrationen von 50 pmol/ml microRNA (-Kontrolle bzw. -Inhibitor 19b) als auch für die geringeren Konzentrationen von $25 \mathrm{pmol} / \mathrm{ml}$ microRNA nachweisbar. Hierbei ließen sich keine signifikanten Unterschiede in der Apoptoserate nach Transfektion mit $50 \mathrm{pmol} / \mathrm{ml}$ microRNA-Kontrolle und $50 \mathrm{pmol} / \mathrm{ml}$ microRNAInhibitor 19b oder bei Transfektion mit $25 \mathrm{pmol} / \mathrm{ml}$ microRNA-Kontrolle und $25 \mathrm{pmol} / \mathrm{ml}$ microRNA-Inhibitor 19b erkennen. Auch der Vergleich der Apoptoseraten nach Transfektion mit verschiedenen Konzentrationen an microRNA (-Kontrolle oder -Inhibitor 
19b) ergab keine signifikanten Unterschiede. Für T-Lymphozyten wurde dieses Phänomen ebenfalls von Zhao et al. (2006) beschrieben. Eine Erhöhung der Konzentration an transfizierter RNA führte in ihren Experimenten nicht zu einer Beeinflussung der Vitalität der T-Lymphozyten.

Die Apoptoseraten der untransfizierten Zellen in den mit microRNA (-Kontrolle oder -Inhibitor 19b) behandelten Proben lagen mit etwa 2\% signifikant unter der Apoptoserate der unbehandelten Probe mit 7,4\%. Wie bei den Jurkat-Zellen kann auch hier vermutet werden, dass es sich um einen systematischen Messfehler handelt oder die microRNAs besser in apopotische Zellen aufgenommen werden.

Insgesamt waren die Apoptoseraten der nachweislich mit microRNA (-Kontrolle oder -Inhibitor 19b) transfizierten Zellen in dieser Arbeit mit bis zu 55\% hoch und zeigten toxische Effekte der microRNAs auf die humanen MNZ. In der Literatur wurden die Apoptoseraten nach Transfektion von humanen MNZ kaum beschrieben. Lediglich Meng et al. (2013) beschrieben die Apoptoseraten von endothelialen Progenitorzellen aus dem peripheren Blut nach Transfektion mit einem Inhibitor von miR-130a und einer Negativkontrolle. Die Autoren verwendeten CD133-positive endotheliale Progenitorzellen, die zunächst sieben Tage mit verschiedenen Wachstumfaktoren differenziert wurden, sodass der Vergleich mit den in dieser Arbeit verwendeten MNZ nur sehr eingeschränkt möglich ist. Der Anteil der durchflusszytometrisch gemessenen Annexin V-positiven Zellen lag bei Meng und Kollegen bei Transfektion mit lentiviralen Vektoren mit der Negativkontrolle bei unter $5 \%$ und bei Transfektion mit dem Inhibitor-130a bei etwa 10\%, sodass die in dieser Arbeit beobachteten toxischen Effekte der microRNAs möglicherweise auf das Transfektionsverfahren zurück zu führen sind. 


\subsection{Effekte von microRNAs auf T-Lymphozyten, B-Lympho- zyten und Monozyten}

Bei MNZ handelt es sich um eine Mischung aus verschiedenen Leukozytenarten. Daher wurde untersucht, ob es bei Transfektion mit microRNA-Kontrolle und microRNAInhibitor 19b Unterschiede in der Transfektions- und Apoptoserate bei T-Lymphozyten, B-Lymphozyten und Monozyten gab.

Die Transfektionsraten lagen bei Transfektion mit der microRNA-Kontrolle für Tund B-Lymphozyten signifikant höher als bei Transfektion mit dem microRNA-Inhibitor 19b. Die Transfektionsrate der B-Lymphozyten war dabei immer höher als die Transfektionsrate der T-Lymphozyten. In der Literatur war weder ein Vergleich von Transfektionsraten von microRNA-Kontrolle und microRNA-Inhibitor in Lymphozyten noch ein direkter Vergleich der Transfektionsraten von B- und T-Lymphozyten auffindbar. Von Di Nicola et al. (1999) wurde jedoch bei Transfektion von T-Lymphozyten mit einem rekombinanten Adenovirus in Kombination mit dem liposomalen Transfektionsreagenz Lipofectamine eine eher geringe Transfektionsrate von 22-24\% (11-12\% bei alleinigem Einsatz des Adenovirus) beschrieben. Bei Transfektion von B-Lymphozyten wurden hingegen von Aung et al. (2015) eine Transfektionsrate von $85 \%$ bei Transfektion mit dem liposomalen Transfektionsreagenz TransIT-TKO transfection reagent gemessen, sodass dies ein Hinweis auf eine höhere Transfektionsrate von B-Lymphozyten sein könnte. Bei den Monozyten konnte die Transfektionsrate nicht bestimmt werden, da in den transfizierten Proben durchflusszytometrisch keine Monozyten nachweisbar waren.

Neben den Transfektionsraten wurden auch die Apoptoseraten der einzelnen Leukozytenarten bestimmt. Einerseits wurde der Anteil der frühapoptotischen Annexin Vpositiven, 7-AAD-negativen Zellen gemessen, andererseits der Anteil an Annexin V- und 7-AAD-positiven spätapoptotischen Zellen. Früh- und spätapoptotische Zellen zeigten die gleichen Tendenzen, sodass sie im Folgenden als apoptotische Zellen zusammengefasst werden. Der Anteil der apoptotischen Zellen war bei T- und B-Lymphozyten bei 
Transfektion mit microRNA(-Kontrolle und -Inhibitor 19b) signifikant höher als bei unbehandelten T- und B-Lymphozyten. Es war jeweils ein signifikant höherer Anteil an apoptotischen T- und B-Lymphozyten bei Transfektion mit microRNA-Inhibitor 19b als bei Transfektion mit microRNA-Kontrolle nachweisbar, sodass eine Beeinflussung der Apoptoserate von T- und B-Lymphozyten durch den microRNA-Inhibitor 19b gezeigt werden konnte. Bei den B-Lymphozyten war der Anteil an apoptotischen Zellen sowohl bei Transfektion mit der microRNA-Kontrolle als auch mit dem microRNA-Inhibitor 19b signifikant höher als bei den T-Lymphozyten. Dieser Trend war ebenso in der unbehandelten Kontrolle nachweisbar, wo die B-Lymphozyten einen signifikant höheren Anteil an apoptotischen Zellen aufwiesen als die T-Lymphozyten. Daher scheinen B-Lymphozyten in einer Zellkultur generell eine höhere Apoptoserate aufzuweisen als T-Lymphozyten.

Die höchste Apoptoserate in der unbehandelten Zellkultur wiesen jedoch die Monozyten auf. Bei ihnen wurde bereits in der unbehandelten Probe ein Anteil an Annexin V-positiven Zellen von $45 \%$ nachgewiesen. Dies könnte der Grund dafür sein, dass in den transfizierten Proben keine Monozyten mehr nachweisbar waren, da hier noch eine erheblich höhere Apoptoserate zu erwarten wäre als in der unbehandelten Zellkultur oder bereits eine Nekrose der Monozyten denkbar wäre. Ein Rückschluss auf die Ursache der in den transfizierten Proben nicht mehr vorhandenen Monozyten lässt sich aus der Literatur aktuell nicht ziehen, da diese Beobachtung so bislang nicht veröffentlicht wurde. Auch von anderen Autoren wurde jedoch die Transfektion von humanen Monozyten als schwierig beschrieben. Von Troegeler et al. (2014) wurden DharmaFECT4 und Lipofectamine 2000 als liposomale Transfektionsreagenzien bei Monozyten getestet. Hierbei zeigten sich eine sehr variable Transfektionseffizienz und eine Beeinträchtigung der Vitalität der Monozyten. Die Testung von HiPerfect Transfection Reagent war bei üblicher Zugabe des RNA-Lipid-Komplexes nach Herstellerangaben zu den bereits in Kultur befindlichen Monozyten ebenfalls sehr toxisch für die Zellen. Durch Reduktion der Konzentration an HiPerfect von 3 auf 1 Volumen\%, Reduktion der Transfektionszeit von 6 auf 4 Stunden und eine reverse Transfektionsmethode (Zugabe der Zellen auf 
die RNA-Lipid-Komplexe) konnte ein erfolgreiches Transfektionsverfahren für Monozyten etabliert werden. Die Transfektionsrate bei Verwendung von fluoreszenzmarkierter RNA lag unter diesen Bedingungen bei etwa $94 \%$ und die Apoptoseraten waren niedrig (Annexin V-positiver und Propidiumiodid-negativer Anteil an transfizierten Monozyten ca. 10\%, Annexin V- und Propidiumiodid-positiver Anteil ca. 4\%). Dieses veränderte Transfektionsprotokoll und HiPerfect als Transfektionsreagenz könnten damit vielversprechende Alternativen zu dem in dieser Arbeit verwendeten Transfektionsprotokoll und dem Transfektionsreagenz siLentFect sein.

Neben einer Optimierung der liposomalen Transfektion könnte auch eine andere Transfektionsmethode in Erwägung gezogen werden. In der Literatur wurde die Elektroporation als Transfektionsmethode für Monozyten beschrieben und Protokolle entwickelt, die eine erfolgreiche Transfektion unter Erhalt von Vitalität und Funktion der Monozyten gewährleisteten (Scherer et al. 2015; Prechtel et al. 2006). Eine weitere alternative Transfektionsmethode könnte die virale Transfektion von Monozyten sein, die effizient ist aber oft zu unspezifischen inflammatorischen und immunogenen Effekten führt (Roth et al. 2002). Zum Ausschluss der Immunogenität der Transfektionsverfahren wurde von Wahlgren et al. (2012) die Transfektion von Lymphozyten und Monozyten mittels Exosomen und Elektroporation untersucht. Die verwendeten Exosomen wurden aus dem peripheren Blut von gesunden Blutspendern gewonnen und könnten dementsprechend aus dem eigenen Blut des Patienten gewonnen werden, sodass sie nicht immunogen wären. In diese Exosomen wurde RNA mittels Elektroporation eingebracht und diese RNA-beladenen Exosomen anschließend mittels Elektroporation in Monozyten und Lymphozyten eingebracht. Es konnte eine dosisabhängige veränderte Genexpression durch Einbringen der RNA in die Zellen nachgewiesen werden Die Vitalität der Zellen war bei Lymphozyten durch die Transfektion nicht verändert, bei Monozyten hingegen signifikant erniedrigt. Auch bei anderen Transfektionsmethoden ist die Vitalität der Zellen, insbesondere der Monozyten also kritisch. Hier könnte eine Optimierung der Zellkulturbedingungen oder eine Stimulierung der Zellen mit bestimmten Substanzen eine Verbesserung bewirken. 
Von Scherer et al. (2015) wurde für die Transfektion von Monozyten mittels Elektroporation eine Optimierung der Zellkulturbedingungen beschrieben. Sie stellten fest, dass das nach Transfektion verwendete Zellkulturmedium essentiell ist, um eine hohe Zellvitalität und Zellfunktionalität von Monozyten zu gewährleisten. Am besten geeignet war hier das Lymphocyte Growth Medium-3 sowie der Einsatz von 20\% humanem Serum. Die Stimulierung von mononukleären Zellen zur Verringerung der Apoptoserate ist in der Literatur ebenfalls beschrieben worden. Von Huang et al. (2012) wurde bei liposomaler Transfektion mit FECT nach 72 Stunden mit dem cell counting Kit 8 eine Vitalität in der unbehandelten Monozytenkultur von 100\%, und in den mit FECT, microRNA-Kontrolle und miR-125b behandelten Ansätzen von etwa 80\% gemessen, wobei die Monozytenkulturen nach der Transfektion mit LPS stimuliert wurden. Ng et al. (2012) beschrieben die Transfektion von tumorassoziierten Makrophagen, die durch Stimulation von Monozyten mit IL-4 und Macrophage colony-stimulating factor generiert wurden. Bei liposomaler Transfektion von pre-miR-511 mit siPORT ${ }^{\mathrm{TM}} \mathrm{NeoFX}^{\mathrm{TM}}$ wurde eine Transfektionsrate von $37,5 \%$ bei einer Vitalität von $73,8 \%$ erreicht. Ähnliches wurde für T-Lymphozyten beschrieben. Zhao et al. (2006) beobachteten bei unstimulierten T-Lymphozyten eine Transfektionsrate von $95 \%$ mit einer Vitalität von 57\%. Nach Stimulation mit IL-2 konnte hingegen eine Transfektionsrate von 93\% bei deutlich verbesserter Vitalität von $82 \%$ gemessen werden. Auch Di Nicola et al. (1999) beschrieben die Transfektion von humanen T-Lymphozyten nach 7-tägiger Kultivierung mit verschiedenen Zytokinen. Die Transfektionsrate bei Verwendung eines Adenovirus in Kombination mit Lipofectamine lag bei Inkubation mit IL-2 plus IL-12 bei etwa $22 \%$ und mit IL-2 plus IL-7 bei etwa $24 \%$.

Für eine erfolgreichere Transfektion von Monozyten und auch Lymphozyten könnten daher eine Optimierung des liposomalen Transfektionsverfahrens, andere Transfektionsmethoden wie Elektroporation oder Exosomen und eine Stimulation der Zellen mit bestimmten Substanzen wie Interleukinen in Frage kommen.

Insgesamt konnten höhere Transfektions- sowie höhere Apoptoseraten für B-Lym- 
phozyten als für T-Lymphozyten ermittelt werden und eine Erhöhung der Apoptoserate durch Transfektion von B- und T-Lymphozyten mit dem microRNA-Inhibitor 19b gezeigt werden. Es zeigten sich jedoch vor allem bei den Monozyten in der Zellkultur hohe Apoptoseraten, sodass eine weitere Optimierung des Transfektionsverfahrens sowie der Zellkulturbedingungen nötig ist, um aussagekräftige Ergebnisse über den Effekt des microRNA-Inhibitors 19b auf die humanen MNZ aus Buffy Coats zu bekommen.

\subsection{Fazit und Ausblick}

Trotz der in den letzten Jahrzehnten erheblich verbesserten Therapie und Lebenserwartung von Patienten mit akuten Leukämien versterben weiterhin Menschen an dieser potentiell tödlichen Erkrankung. Daher sollten in der vorliegenden Arbeit Grundlagen zur Entwicklung eines neuen Therapieverfahrens für akute Leukämien untersucht werden. Im Mittelpunkt stand hierbei das microRNA-Cluster 17-92, das in vielen hämatoonkologischen Erkrankungen überexprimiert wird und daher als potentielles Onkogen identifiziert wurde. Als Beispiel für akute Leukämien wurde in der vorliegenden Arbeit die T-ALL-Zelllinie Jurkat untersucht. Durch Transfektion von Jurkat-Zellen mit dem microRNA-Inhibitor 19b konnte eine signifikante Erhöhung der Apoptoserate nachgewiesen werden. In der vorliegenden Arbeit wurde bei der B-Zell-Lymphomlinie SU-DHL-4 mit den verwendeten liposomalen Transfektionsreagenzien keine ausreichende Transfektionsrate erreicht. Zukünftig könnten daher andere Transfektionsmethoden für SU-DHL-4Zellen zum Einsatz kommen oder eine andere B-Zelllinie für die Untersuchung ausgewählt werden, um den Effekt des microRNA-Inhibitors 19b auf B-Lymphozyten untersuchen zu können.

Essentiell für den Einsatz des Verfahrens als Arzneimittel bei Menschen ist die Untersuchung der Wirkung auf gesunde Zellen. In der vorliegenden Arbeit zeigten mit microRNAs transfizierte MNZ hohe Apoptoseraten, was auf eine hohe Toxizität der microRNAs hindeutete. Dies war unabhängig von der Funktion der transfizierten microR- 
NAs auch für die microRNA-Kontrolle ohne inhibitorische Funktion nachweisbar, sodass zunächst der Transfektionsmechanismus und die Zellkulturbedingungen für humane Primärzellen verbessert werden müssten. Nach Etablierung einer Transfektionsmethode mit geringerer Toxizität wäre es darüber hinaus interessant, eine Mischkultur aus humanen Primärzellen und Leukämiezellen wie Jurkat-Zellen zu untersuchen. Hiermit könnte getestet werden, ob microRNA-Inhibitor 19b in Leukämiezellen stärker zu einer Apoptose führt als in gesunden Zellen. Ein weiterer Schritt wäre die Untersuchung der Wirksamkeit des microRNA-Inhibitors 19b im Tiermodell, um einen ersten Eindruck der Wirkung in vivo zu erhalten. Waren diese Schritte erfolgreich, könnte eine klinische Studie mit dem microRNA-Inhibitor 19b für Patienten mit ALL oder Krebserkrankungen, die miR-19 überexprimieren, in Frage kommen.

Zusätzlich wäre es interessant, nach anderen microRNAs zu suchen, die in der ALL überexprimiert werden und zur Malignität der Erkrankung beitragen, um alternative Inhibitoren zu testen oder gegebenenfalls eine Kombination von mehreren Inhibitoren zu ermöglichen. 


\section{$5 \quad$ Zusammenfassung}

Die Dysregulation von microRNAs scheint ein entscheidender Faktor bei Leukämien zu sein. Daher könnten Therapien möglich sein, die auf die veränderte Expression von proliferationsregulierenden microRNAs abzielen. Das microRNA-Cluster 17-92 wurde als potentielles Onkogen identifiziert. In der vorliegenden Arbeit wurde untersucht, ob durch Hemmung der in diesem Cluster wichtigsten microRNA-19 eine erhöhte Apoptoserate in Zellen ausgelöst werden kann. Hierfür wurde der microRNA-Inhibitor 19b mittels liposomaler Transfektion in eine T-Zelllinie (Jurkat), eine B-Zelllinie (SU-DHL-4) sowie humane mononukleäre Zellen von Blutspendern eingebracht. Durchflusszytometrisch wurden die Transfektionsrate als Anteil der mit fluoreszenzmarkierter microRNA-Kontrolle transfizierten Zellen sowie die Apoptoserate als Anteil der Annexin V-positiven Zellen gemessen. Für jede Zellart wurden die Transfektionsbedingungen mit der höchsten Transfektionsrate ermittelt. Für SU-DHL-4-Zellen konnte mit den verwendeten liposomalen Transfektionsreagenzien keine ausreichende Transfektionsrate (maximal 12\%) erzielt werden, um den microRNA-Inhibitor 19b testen zu können. Für die Jurkat-Zelllinie konnte mit dem Transfektionsreagenz siLentFect eine Transfektionsrate von maximal $41 \%$ er-

reicht werden. Durch Transfektion mit dem microRNA-Inhibitor 19b wurde ein Anstieg der Apoptoserate auf 34\% im Vergleich zu unbehandelten (4,3\%) und mit microRNAKontrolle transfizierten Jurkat-Zellen (15\%) nachgewiesen werden. Bei den mononukleären Zellen wurde ebenfalls ein Anstieg der Apoptoserate nach Transfektion mit dem microRNA-Inhibitor 19b im Vergleich zu unbehandelten Zellen (Apoptoserate 7\%) festgestellt. Der Anstieg der Apoptoserate war jedoch bei den mit microRNA-Kontrolle $(55 \%)$ und microRNA-Inhibitor 19b (50\%) transfizierten Zellen nicht signifikant ver- 
schieden. Durch Halbierung der Konzentration an microRNA-Kontrolle und microRNAInhibitor 19b konnte keine signifikante Reduzierung der Apoptoseraten erzielt werden. Insgesamt waren die Apoptoseraten bei Transfektion von humanen primären Leukozyten mit bis zu 55\% hoch, während die Transfektionsrate nur bei maximal $17 \%$ lag. Zusätzlich wurde untersucht, ob sich die Transfektions- und Apoptoseraten von Subtypen der mononukleären Zellen (T-Lymphozyten, B-Lymphozyten oder Monozyten) signifikant unterscheiden. Die Apoptoserate der Monozyten lag bereits in der unbehandelten Probe bei 45\%, und in den transfizierten Proben waren keine Monozyten nachweisbar. Bei den B-Lymphozyten zeigten sich höhere Transfektions- und Apoptoseraten als bei den T-Lymphozyten. Die Apoptoserate bei Transfektion mit dem microRNA-Inhibitor 19b lag bei T- und B-Lymphozyten signifikant über der Apoptoserate bei Transfektion mit der microRNA-Kontrolle, sodass eine Wirkung des Inhibitors auch bei Lymphozyten von gesunden Kontrollpersonen beobachtet werden konnte.

Insgesamt konnte durch den microRNA-Inhibitor 19b eine Erhöhung der Apoptoserate in Jurkat-Zellen nachgewiesen werden, was ein erster Hinweis auf eine Wirksamkeit der Substanz gegen Leukämien sein könnte. Die apoptotische Wirkung des microRNAInhibitors 19b auf mononukleäre Zellen weist jedoch auf ein hohes Potential für unerwünschte Wirkungen hin. Vor dem Einsatz in klinischen Studien sind daher weitere Arbeiten zur Verbesserung der Kultur- und Transfektionsbedingungen erforderlich. 


\section{$6 \quad$ Literaturverzeichnis}

Alizadeh S, Kaviani S, Soleimani M, Abroun S, Kashani-Khatib Z, Asgharzadeh A, Dargahi H, Mousavi R (2014): Mir-55 inhibition can reduce cell proliferation and induce apoptosis in Jurkat (Acute $\mathrm{T}$ cell Leukemia) cell line. Iran J Ped Hematol Oncol $\underline{4}(4), 141-150$

An N, Tao Z, Li S, Xing H, Tang K, Tian Z, Rao Q, Wang M, Wang J (2016): Construction of a new anti-CD19 chimeric antigen receptor and the anti-leukemia function study of the transduced T cells. Oncotarget 7 (9), 10638-10649

Aung LL, Mouradian MM, Dhib-.Jalbut S, Balashov KE (2015): MMP-9 expression is increased in B lymphocytes during multiple sclerosis exacerbation and is regulated by microRNA-320a. J Neuroimmunol 278, 185- 189

Bartel DP (2009): MicroRNAs: target recognition and regulatory functions. Cell 136 (2), 215-233

Bessis N, Garcia-Cozar FJ, Boissier MC (2004): Immune responses to gene therapy vectors: influence on vector function and effector mechanisms. Gene Ther 11 (1), 810-817

Brennecke J, Cohen SM (2003): Towards a complete description of the microRNA complement of animal genomes. Genome Biol $\underline{4}$ (9), 228

Calin GA, Sevignani C, Dumitru CD, Hyslop T, Noch E, Yendamuri S, Shimizu M, Rattan S, Bullrich F, Negrini M (2004): Human microRNA genes are frequently located at fragile sites and genomic regions involved in cancers. Proc Natl Acad Sci USA 101 (9), 2999-3004

Chen CZ, Li L, Lodish HF, Bartel DP (2004): MicroRNAs modulate hematopoietic lineage differentiation. Science 303 (5654), 83-86 
Chettab K, Roux S, Mathe D, Cros-Perrial E, Lafond M, Lafon C, Dumontet C, Mestas JL (2015): Spatial and Temporal Control of Cavitation Allows High In Vitro Transfection Efficiency in the Absence of Transfection Reagents or Contrast Agents. PLoS One $\underline{10}(8), 0134247$

Conrad AT, Dittel BN (2011): Taming of macrophage and microglial cell activation by microRNA-124. Cell Res 21 (2), 213- 216

Croce CM (2009): Causes and consequences of microRNA dysregulation in cancer. Nat Rev Genet 10 (10), 704-714

Dai H, Wang Y, Lu X, Han W (2016): Chimeric Antigen Receptors Modified T-Cells for Cancer Therapy. JNCI J Natl Cancer Inst 108 (7), 439

Danielson LS, Reavie L, Coussens M, Davalos V, Castillo-Martin M, Guijarro MV, Coffre M, Cordon-Cardo C, Aifantis I, lbrahim S, Liu C, Koralov SB, Hernando E (2015): Limited miR-17-92 overexpression drives hematologic malignancies. Leuk Res $\underline{39}$ (3), 335-341

de Oliveira JC, Scrideli CA, Brassesco MS, Morales AG, Pezuk JA, Queiroz RDP, Yunes TA, Brandalise SR, Tone LG (2012): Differential miRNA expression in childhood acute lymphoblastic leukemia and association with clinical and biological features. Leuk Res 86 (3), 293-298

Di Nicola M, Milanesi M, Magni M, Bregni M, Carlo-Stella C, Longoni P, Tomanin R, Ravagnani F, Scarpa M, Jordan C (1999): Recombinant adenoviral vector-lipofectAMINE complex for gene transduction into human T lymphocytes. Hum Gene Ther 10 (11), 1875-1884

Doench JG, Sharp PA (2004): Specificity of microRNA target selection in translational repression. Genes Dev 18 (5), 504-511

Esau C, Davis S, Murray SF, Yu XX, Pandey SK, Pear M, Watts L, Booten SL, Graham M, McKay R (2006): miR-122 regulation of lipid metabolism revealed by in vivo antisense targeting. Cell Metab $\underline{3}(2), 87-98$

Eulalio A, Huntzinger E, Mishihara T, Rehwinkel J, Fauser M, Izaurralde E (2009): Deadenylation is a widespread effect of miRNA regulation. RNA 15 (1), 21-32

Ferlay J, Steliarova-Foucher E, Lortet-Tieulent J, Rosso S, Coebergh JWW, Comber H, Forman D, Bray F (2013): Cancer incidence and mortality patterns in Europe: estimates for 40 countries in 2012. Eur J Cancer 49 (6), 1374-1403 
Garzon R, Marcucci G, Croce CM (2010):Targeting microRNAs in cancer: rationale, strategies and challenges. Nat Rev Drug Discov $\underline{9}$ (10), 775-789

Gökbuget N, Stanze D, Beck J, Diedrich H, Horst HA, Hüttmann A, Kobbe G, Kreuzer KA, Leimer L (2012): Outcome of relapsed adult lymphoblastic leukemia depends on response to salvage chemotherapy, prognostic factors, and performance of stem cell transplantation. Blood 120 (10), 2032-2041

Gomez IG, MacKenna DA, Johnson BG, Kaimal V, Roach AM, Ren S, Nakagawa N, Xin C, Newitt R, Pandya S (2015): Anti-microRNA-21 oligonucleotides prevent Alport nephropathy progression by stimulating metabolic pathways. J Clin Invest $\underline{125}$ (1), $141-156$

Guo M, Mao X, Ji Q, Lang M, Li S, Peng Y, Zhou W, Xiong B, Zeng Q (2010): miR146a in PBMCs modulates Th1 function in patients with acute coronary syndrome. Immunol Cell Biol 88 (5), 555-564

Hayashita Y, Osada H, Tatematsu Y, Yamada H, Yanagisawa K, Tomida S, Yatabe Y, Kawahara K, Sekido Y, Takahashi T (2005): A polycistronic microRNA cluster, miR-17-92, is overexpressed in human lung cancers and enhances cell proliferation. Cancer Res $\underline{65}$ (21), 9628- 9632

He L, Thomson JM, Hemann MT, Hernando-Monge E, Mu D, Goodson S, Powers S, Cordon-Cardo C, Lowe SW, Hannon GJ, Hammond SM (2005): A microRNA polycistron as a potential human oncogene. Nature 435 (7043), 828-833

Ho LJ, Chang WL, Chen A, Chao P, Lai JH (2013): Differential immunomodulatory effects by Tripterygium wilfordii Hook f-derived refined extract PG27 and its purified component PG490 (triptolide) in human peripheral blood T cells: potential therapeutics for arthritis and possible mechanisms explaining in part Chinese herbal theory "Junn-Chenn-Zuou-SS".J Transl Med 11, 294

Huang HC, Yu HR, Huang LT, Huang HC, Chen RF, Lin IC, On CY Hsu TY, Yang KD (2012): miRNA-125b regulates $\mathrm{TNF}-\alpha$ production in $\mathrm{CD} 14+$ neonatal monocytes via post-transcriptional regulation. J Leukoc Biol 92 (1), 171-182

Huang HP, Liu WJ, Guo QL, Bai YQ (2016): Effect of silencing HOXA5 gene expression using RNA interference on cell cycle and apoptosis in Jurkat cells. Int J Mol Med 37 (3), 669-678 
Hutvagner G, Simard MJ, Mello CC, Zamore PD (2004): Sequence-specific inhibition of small RNA function. PLoS Biol 2 (4), 465-475

Inomata M, Tagawa H, Guo YM, Kameoka Y Takahashi N, Sawada K (2009): MicroRNA17-92 down-regulates expression of distinct targets in different B-cell lymphoma subtypes. Blood 113 (2), 396-402

Janssen HLA, Reesink HW, Lawitz EJ, Zeuzem S, Rodriguez-Torres M, Patel K, van der Meer AJ, Patick AK, Chen A, Zhou Y (2013): Treatment of HCV infection by targeting microRNA. N Engl J Med 368 (18), 1685-1694

Kaestner L, Scholz A, Lipp P (2015): Conceptual and technical aspects of transfection and gene delivery. Bioorg Med Chem Lett 25 (6), 1171-1176

Kantarjian H, Thomas D, Jorgensen J, Kebriaci P, Jabbour E, Rytting M, York S, Ravandi F, Garris R, Kwari M (2013): Results of inotuzumab ozogamicin, a CD22 monoclonal antibody, in refractory and relapsed acute lymphocytic leukemia. Cancer 119 (15), 27282736

Kaur H, Arora A, Wengel J, Maiti S (2006): Thermodynamic, counterion, and hydration effects for the incorporation of locked nucleic acid nucleotides into DNA duplexes. Biochemistry 45 (23), 7347-7355

Kingston RE, Chen CA, Okayama H (2001): Calcium phosphate transfection. Gurr Protoc Immunol Chapter 10

Knoll S, Emmrich S, Pützer BM (2013): The E2F1-miRNA cancer progression network. Adv Exp Med Biol 774, 135-147

Krützfeldt J, Rajewsky N, Braich R, Rajeev KG, Tuschl T, Manoharan M, Stoffel M (2005): Silencing of microRNAs in vivo with 'antagomirs'. Nature 438 (7068), 685-689

Lanford RE, Hildebrandt-Eriksen ES, Petri A, Persson R, Lindow M, Munk ME, Kauppinen S, Orum H (2010): Therapeutic silencing of microRNA-122 in primates with chronic hepatitis C virus infection. Science $\underline{321}$ (5962), 198-201

Lewis, BP, Shih IH, Jones-Rhoades MW, Bartel DP, Burge CB (2003): Prediction of mammalian microRNA targets. Cell $\underline{115}(7), 787-798$ 
Lewis BP, Burge CB, Bartel DP (2005): Conserved seed pairing, often flanked by adenosines, indicates that thousands of human genes are microRNA targets. Cell 120 (1), $15-20$

Li Q, Lin L, Li W (2014): Identification of circulating microRNAs as biomarkers in diagnosis of hematologic cancers: a meta-analysis. Tumour Biol 35 (10), 10467-10478

Li XJ, Luo XQ, Han BW, Duan FT, Wei PP, Chen YQ (2013): MicroRNA-100/99a, deregulated in acute lymphoblastic leukaemia, suppress proliferation and promote apoptosis by regulating the FKBP51 and IGF1R/mTOR signalling pathways. Br J Cancer 109 (8), 2189-2198

Li YP, Gottwein JM, Scheel TK, Jensen TB, Bukh J (2011): MicroRNA-122 antagonism against hepatitis $\mathrm{C}$ virus genotypes 1-6 and reduced efficacy by host RNA insertion or mutations in the HCV 5' UTR. Proc Natl Acad Sci USA 108 (12), 4991-4996

Lu T, Getz G, Miska EA, Alvarez-Saavedra E, Lamb J, Peck D, Sweet-Cordero A, Ebert BL, Mak RH Ferrando AA (2005): MicroRNA expression profiles classify human cancers. Nature 485 (7043), 834-838

Majumdar M, Ratho R, Chawla Y, Singh MP (2014): Evaluating the role of low-speed centrifugation towards transfecting human peripheral blood mononuclear cell culture. Indian J Med Microbiol 32 (2), 164-168

Matsubara H, Takeuchi T, Nishikawa E, Yanagisawa K, Hayashita Y, Ebi H, Yamada H, Suzuki M, Nagino M, Nimura Y (2007): Apoptosis induction by antisense oligonucleotides against miR-17-5p and miR-20a in lung cancers overexpressing miR-1792. Oncogene 26 (41), 6099-6105

Mavrakis KJ, Van der Meulen J, Wolfe AL, Liu X, Mets E, Taghon T, Khan AA, Setty M, Setti M, Rondou P (2011): A cooperative microRNA-tumor suppressor gene network in acute T-cell lymphoblastic leukemia (T-ALL). Nat Genet $\underline{43}$ (7), 673-678

McClelland AD, Herman-Edelstein M, Korners R, Jha JC, Winbanks CE, Hagiwara S, Gregorevic P, Kantharidis P, Cooper ME (2005): miR-21 promotes renal fibrosis in diabetic nephropathy by targeting PTEN and SMAD7. Clin Sci 129 (12), 1237-1249

Meng S, Cao J, Zhang X, Fan Y, Fang L, Wang C, Lu Z, Fu D, Li Y (2013): Downregulation of microRNA-130a contributes to endothelial progenitor cell dysfunction in diabetic patients via its target Runx3. PLoS One $\underline{8}$ (7), c68611 
Mogilyansky E, Rigoutsos I (2013): The miR-17/92 cluster: a comprehensive update on its genomics, genetics, functions and increasingly important and numerous roles in health and disease. Cell Death Differ 20 (12), 1603-1614

Müller OJ, Ksienzyk J, Katus HA (2008): Gene-therapy delivery strategies in cardiology. Future Cardiol $\underline{4}$ (2), 135-150

Murphy BL, Obad S, Bihannic L, Ayrault O, Zindy F, Kauppinen S, Roussel MF (2013): Silencing of the miR-17 92 cluster family inhibits medulloblastoma progression. Cancer Res $\underline{73}$ (23), 7068-7078

Nakasa T, Shibuya H, Nagata Y, Niimoto T, Ochi M (2011): The inhibitory effect of microRNA-146a expression on bone destruction in collagen-induced arthritis. Arthritis Rheum $\underline{63}$ (6), 1582-1590

Ng YS, Roca H, Fuller D, Sud S, Pienta KJ (2012): Chemical transfection of dyeconjugated microRNA precursors for microRNA functional analysis of M2 macrophages. J Cell Biochem 113 (5), 1714-1723

O’Donnell KA, Wentzel EA, Zeller KI, Dang CV, Mendell JT (2005): c-Myc-regulated microRNAs modulate E2F1 expression. Nature 485 (7043), 839-843

Ohyashiki JH, Umezu T, Kobayashi C, Hamamura RS, Tanaka M, Kuroda M, Ohyashiki K (2010): Impact on cell to plasma ratio of miR-92a in patients with acute leukemia: in vivo assessment of cell to plasma ratio of miR-92a. BMC Res Notes 3, 347

Olive V, Bennett MJ, Walker JC, Ma C, Jiang I, Cordon-Cardo C, Li QJ, Lowe SW, Hannon GJ, He L (2009): miR-19 is a key oncogenic component of mir-17-92. Genes Dev 23 (24), 2839-2849

Olive V, Jiang I, He L (2010): mir-17-92, a cluster of miRNAs in the midst of the cancer network. Int J Biochem Cell Biol $\underline{42}$ (8), 1348-1354

Olive V, Sabio E, Bennett MJ, De Jong CS, Biton A, McGann JC, Greaney SK, Sodir NM, Zhou AY, Balakrishnan A (2013): A component of the mir-17-92 polycistronic oncomir promotes oncogene-dependent apoptosis. Elife 2, e00822

Ottmann OG, Pfeifer H (2009): Management of Philadelphia chromosome-positive acute lymphoblastic leukemia (Ph+ ALL). Hematology Am Soc Hematol Educ Program $\underline{2009}(1), 371-381$ 
Patrick DM, Montgomery RL, Qi X, Obad S, Kauppinen S, Hill JA, van Rooij E, Olson EN (2010): Stress-dependent cardiac remodeling occurs in the absence of microRNA21 in mice. J Glin Invest 120 (11), 3912-3916

Pedziwiatr-Werbicka E, Fuentes E, Dzmitruk V, Sanchez-Nieves J, Sudas M, Drozd E, Shakhbazau A, Shcharbin D, de la Mata FJ, Gomez-Ramirez R (2013): Novel 'Si-C' carbosilane dendrimers as carriers for anti-HIV nucleic acids: studies on complexation and interaction with blood cells. Colloids Surf B Biointerfaces 109, 183-189

Prechtel AT, Turza NM, Theodoridis AA, Kummer M, Steinkasserer A (2006): Small interfering RNA (siRNA) delivery into monocyte-derived dendritic cells by electroporation. J Immunol Methods 311 (1-2), 139-152

Preiss J, Dornoff W, Schmieder A, Honecker F, Classen J: Taschenbuch Onkologie interdisziplinaere Empfehlungen zur Therapie 17. Auflage. W. Zuckschwerdt Verlag, München 2014

Roth MD, Cheng Q, Harui A, Basak SK, Mitani K, Low TA, Kiertscher SM (2002): Helper-dependent adenoviral vectors efficiently express transgenes in human dendritic cells but still stimulate antiviral immune responses. J Immunol 169 (8), 4651-4656

Sather H (1986): Age at diagnosis in childhood acute lymphoblastic leukemia. Med Pediatr Oncol $\underline{14}(3), 166-172$

Sawyers CL, Denny CT, Witte ON (1991): Leukemia and the disruption of normal hematopoiesis. Cell 64 (2), 337-350

Schachtschabel U, Pavlinkowa G, Lou D, Köhler H (1996): Antibody-mediated gene delivery for B-cell lymphoma in vitro. Cancer Gene Ther $\underline{3}$ (6), 365-372

Scherer O, Maeß MB, Lindner S, Garscha U, Weinigel C, Rummler S, Werz O, Lorkowski S (2015): A procedure for efficient non-viral siRNA transfection of primary human monocytes using nucleofection. J Immunol Methods 422, 118-124

Scherr M, Venturini L, Battmer K, Schaller-Schoenitz M, Schaefer D, Dallmann I, Ganser A, Eder M (2007): Lentivirus-mediated antagomir expression for specific inhibition of miRNA function. Nucleic Acids Res 35 (22), e149

Schrappe M, Camitta B, Pui CH, Eden T, Gaynon P, Gustafsson G, Janka-Schaub GE, Kamps W, Masera G, Sallan S (2000): Long-term results of large prospective trials in childhood acute lymphoblastic leukemia. Leukemia 14 (12), 2193-2194 
Sharifi M, Salehi R, Gheisari Y, Kazemi M (2014): Inhibition of microRNA miR-92a induces apoptosis and inhibits cell proliferation in human acute promyelocytic leukemia through modulation of p63 expression. Mol Biol Rep 41 (5), 2799-2808

Shcharbin D, Shakhbazau A, Bryszewska M (2013): Poly(amidoamine) dendrimer complexes as a platform for gene delivery. Expert Opin Drug Deliv 10 (12), 1687-1698

Shimizu S, Yadav SS, An DS (2016): Stable Delivery of CCR5-Directed shRNA into Human Primary Peripheral Blood Mononuclear Cells and Hematopoietic Stem/Progenitor Cells via a Lentiviral Vector. Methods Mol Biol 1364, 235-248

Siegel RL, Miller KD, Jemal A (2016): Cancer statistics, 2016. CA Cancer J Clin 66 (1), $7-30$

Singh A, Palanichamy JK, Ramalingam P, Kassab MA, Bhagat M, Andrabi R, Luthra K, Sinha S, Chattopadhyay P (2014): Long-term suppression of HIV-1C virus production in human peripheral blood mononuclear cells by LTR heterochromatization with a short double-stranded RNA. Antimicrob Chemother 69 (2), 404-415

Suarez Y, Fernandez-Hernando C, Yu J, Gerber SA, Harrison KD, Pober JS, IruelaArispc ML; Merkenschlager M, Sessa WC (2008): Dicer-dependent endothelial microRNAs are necessary for postnatal angiogenesis. Proc Natl Acad Sci USA 105 (37), 14082-14087

Tano N, Kim HW, Ashraf M (2011): microRNA-150 regulates mobilization and migration of bone marrow-derived mononuclear cells by targeting Cxcr4. PLoS One $\underline{6}(10)$, e23114

Tanzer A, Stadler PF (2004): Molecular evolution of a microRNA cluster. J Mol Biol $\underline{339}(2), 327-335$

Thum T, Gross C, Fiedler J, Fischer T, Kissler S, Bussen M, Galuppo P, Just S, Rottbauer W, Frantz S (2008): MicroRNA-21 contributes to myocardial disease by stimulating MAP kinase signalling in fibroblasts. Nature $\underline{456}$ (7224), 980-984

Topp MS, Gökbuget N, Zugmaier G, Degenhard E, Goebeler ME, Klinger M, Neumann SA, Horst HA, Raff T, Viardot A (2012): Long-term follow-up of hematologic relapsefree survival in a phase 2 study of blinatumomab in patients with MRD in B-lineage ALL. Blood $2012 \underline{120}$ (26), 5185-5187

Troegeler A, Lastrucci C, Duval C, Tanne A, Cougoule C, Maridonneau-Parini I, Neyrolles O, Lugo-Villarino G (2014): An efficient siRNA-mediated gene silencing in 
primary human monocytes, dendritic cells and macrophages. Immunol Cell Biol $\underline{92}$ (8), 699-708

Undi RB, Kandi R, Gutti RK (2013): MicroRNAs as Haematopoiesis Regulators. Adv Hematol 2013, 695754

Unlu S, Tang S, Wang E, Wang En, Martinez I, Tang D, Bianchi ME, Zeh 3rd HJ, Lotze MT (2012): Damage associated molecular pattern molecule-induced microRNAs (DAMPmiRs) in human peripheral blood mononuclear cells. PLoS One 7 (6), e38899

Ventura A, Young AG, Winslow MM, Lintault L, Meissner A, Erkeland SJ, Newman J, Bronson RT, Crowley D, Stone JR (2008): Targeted deletion reveals essential and overlapping functions of the miR-17 through 92 family of miRNA clusters. Cell 132 (5), 875-886

Wahlgren J, De L Karlson T, Brisslert M, Vaziri Sani F, Telemo E, Sunnerhagen P, Valadi H (2012): Plasma exosomes can deliver exogenous short interfering RNA to monocytes and lymphocytes. Nucleic Acids Res 40 (17), e130

Woods K, Thomson TM, Hammond SM (2007): Direct regulation of an oncogenic microRNA cluster by E2F transcription factors. J Biol Chem 282 (4), 2130-2134

Xiao C, Srinivasan L, Calado DP, Patterson HC, Zhang B, Wang J, Henderson JM, Kutok JL, Rajewsky K (2008): Lymphoproliferative disease and autoimmunity in mice with increased miR-17-92 expression in lymphocytes. Nat Immunol 9 (4) 405-414

Xu Q, Meng S, Liu B, Li MQ, Li Y, Fang L, Li YG (2014): MicroRNA-130a regulates autophagy of endothelial progenitor cells through Runx3. Clin Exp Pharmacol Physiol 41 (5), 351-357

Zamore PD, Haley, B (2005): Ribo-gnome: the big world of small RNAs. Science 309 (5740), 1519-1524

Zhang H, Shykind B, Sun T (2012): Approaches to manipulating microRNAs in neurogenesis. Front Neurosci $\underline{6}, 196$

Zhao Y, Zheng Z, Cohen CJ, Gattinoni L, Palmer DC, Restifo NP, Rosenberg SA, Morgan RA (2006): High-efficiency transfection of primary human and mouse $T$ lymphocytes using RNA electroporation. Mol Ther 13 (1), 151-159 
Zheng W, Wu Y, Huang W (2015): Down-regulation of nectin-4 inhibits apoptosis in systemic lupus erythematous (SLE) through targeting Bcl-2/Bax pathway. Int J Clin Exp Pathol $\underline{8}$ (9), 10915-10921 


\section{Danksagung}

Mein besonder Dank gilt Herrn Prof. Dr. med. T. Legler, da er mir die Erstellung einer experimentellen Doktorarbeit in der Abteilung Transfusionsmedizin der Universitätsmedizin Göttingen ermöglicht hat, und Herrn Dr. rer. nat. H. Budde, der mich jederzeit hervorragend und konstruktiv betreut hat. Zudem möchte ich mich bei Frau S. Papert bedanken, die mir die nötigen Labortechniken beigebracht hat. Durch diese herausragende Betreuung war ein erfolgreicher Abschluss der Arbeit erst möglich. Weiterhin danke ich Herrn Dr. B. Winter für seine konstruktive Kritik und zudem Herrn M. Rau für die formale Korrektur der hier vorliegenden Arbeit. Zudem möchte ich mich bei allen Blutspenderinnen und Blutspendern für ihre Zustimmung zur wissenschaftlichen Verwendung ihrer Blutbestandteile bedanken. 


\section{Lebenslauf}

Mein Name ist Anne Lone Rau und ich wurde am 30.April 1985 in Bad Oldesloe geboren. Ich besuchte von 1991 bis 1995 die Grundschule Ratzeburg-St. Georgsberg und anschließend bis 2005 die Lauenburgische Gelehrtenschule in Ratzeburg. Das Schuljahr 2002/2003 verbrachte ich im Rahmen des Rotary Youth Exchange am Braemar College Woodend in Australien. Nach meinem erfolgeich bestandenen Abitur an der Lauenburgischen Gelehrtenschule im Mai 2005 begann ich im Oktober 2005 mein Studium der Humanmedizin an der Christian-Albrechts-Universität zu Kiel. Dieses schloss ich 2012 erfolgreich ab. Nach Erhalt der ärztlichen Approbation begann ich im Oktober 2012 eine Weiterbildungsstelle an der Medizinischen Klinik des Diakonissenkrankenhauses Flensburg. Im Oktober 2013 wechselte ich in die Abteilung Transfusionsmedizin der Universitätsmedizin Göttingen. Dort begann ich meine hier beschriebene Dissertation sowie meine Weiterbildung zur Fachärztin für Transfusionsmedizin. 